\title{
Tu Kaha: Nga Mana Wahine \\ Exploring the role of Mana Wahine in the Development of Te Whare Rokiroki Māori Women's Refuge
}

\section{Tairawhiti Veronique Turner}

\author{
A thesis submitted as partial fulfilment of a \\ Master of Development Studies (MDS)
}

School of Geography, Environment and Earth Sciences

Victoria University of Wellington 


\begin{abstract}
Whānau are the building blocks of society and their well-being is critical to strong, vibrant and connected communities. When a women or child is beaten, abused, or worse killed as a result of family violence, individuals are adversely affected, whānau suffer and wider communities in New Zealand are impoverished. From the margins of New Zealand society, Māori women are leading development campaigns that seek to end violence against women and children, uphold their human rights and freedoms and challenge oppressive colonial ideologies which are hegemonic and masculinist. Their work is part of local, national and global agendas to end violence and bring about long-term, positive change. They are a part of the decolonisation agenda within which many Māori actively campaign.
\end{abstract}

This thesis brings together theory and practice to explore such a campaign. The overall goal is to explore the role of Mana Wahine in the development of Te Whare Rokiroki Māori Women's Refuge. Mana Wahine is a theory and ideological framework which is centred on Māori world views and ways of knowing. It is also a tool for analysing situations and events and has been adopted to create space for Māori women to tell their stories and develop ideas.

This thesis seeks to achieve the following aims:

- explore the meaning of Māori development in a Refuge environment;

- investigate the expression of Mana Wahine by Māori women Refuge advocates; and

- identify the extent to which Mana Wahine has influenced decolonisation.

The research framework which informs the overall approach comprises a: Kaupapa Māori epistemology, Mana Wahine and Qualitative methodologies and interviews. This thesis joins the Refuge in its pursuit for Tino Rangatiratanga (sovereignty) and contributes to the growing body of Mana Wahine knowledge.

The conclusions of this thesis assert development within the Refuge means women and children leading lives free from violence and abuse. A Mana Wahine perspective is critical to the development of the Refuge and achieving positive, long-term change. At a fundamental level, the means through which development and change is achieved is Māori culture, Tikanga and Te Reo.

The women of Te Whare Rokiroki are unsung heroines whose stories of commitment, sacrifice, learning, determination, anger, resistance and generosity has to be told. 


\section{TABLE OF CONTENTS}

TABLE OF CONTENTS

Situating this Thesis within the School of Geography, Environment and Earth Sciences (SGEES)

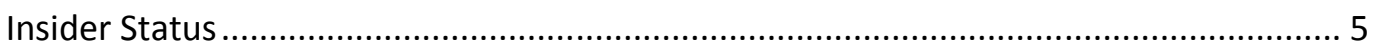

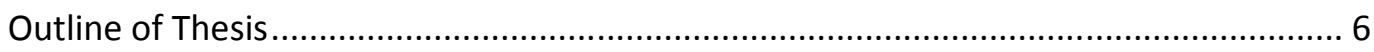

CHAPTER TWO

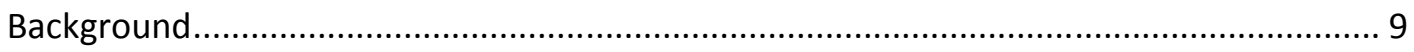

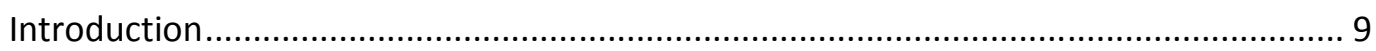

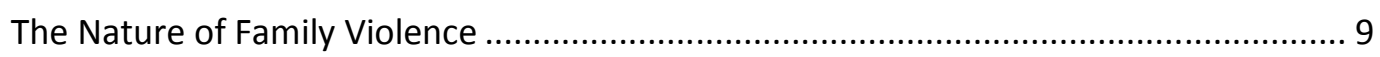

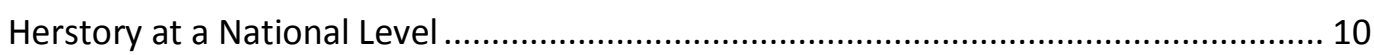

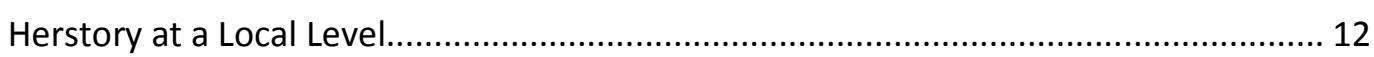

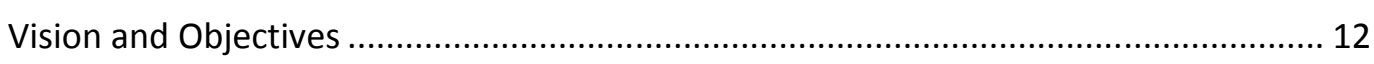

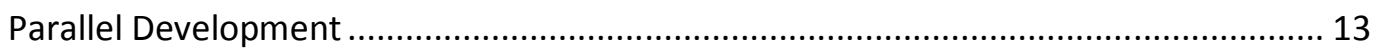

Family Violence in New Zealand ................................................................................. 14

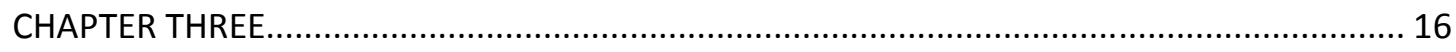

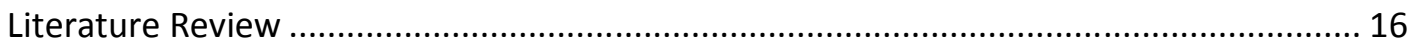

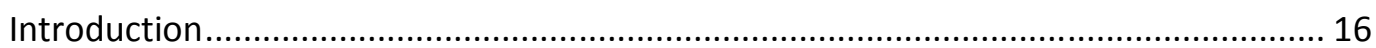

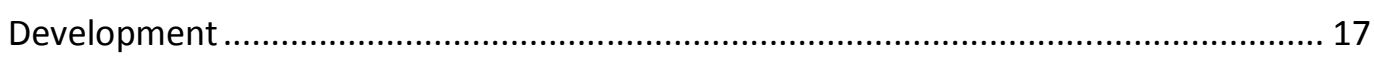

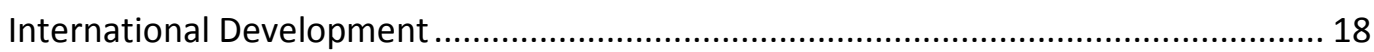

International approaches to address violence against women .................................... 21

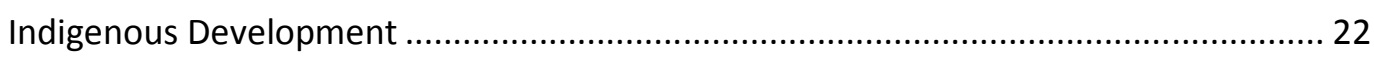

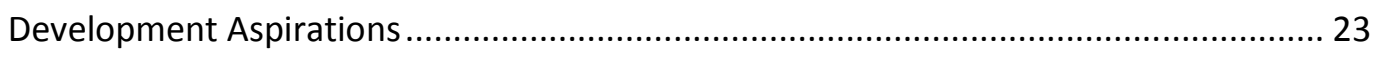

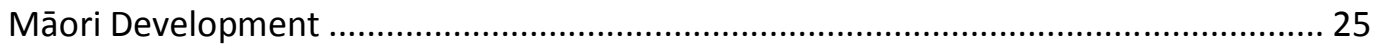

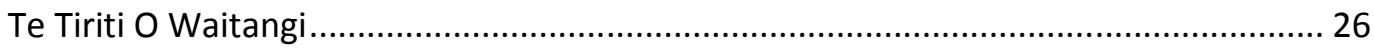

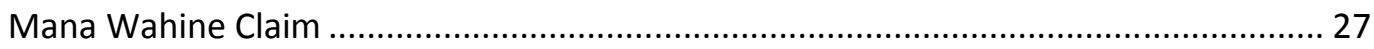




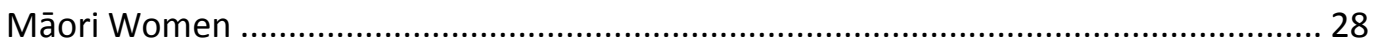

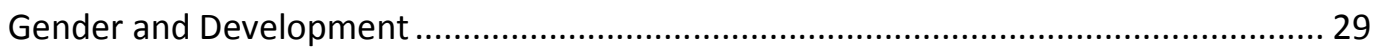

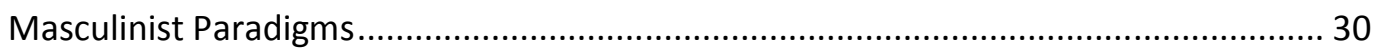

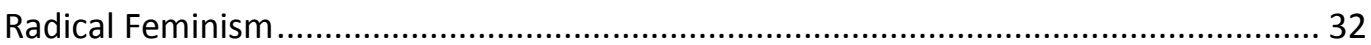

Consciousness-raising groups........................................................................ 33

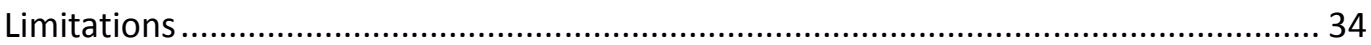

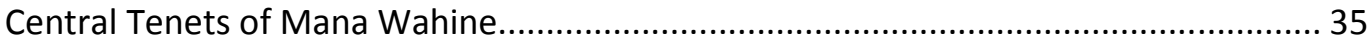

Marginalisation and Mana Wahine as a site for resistance .................................. 36

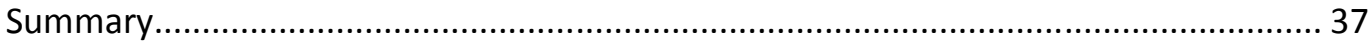

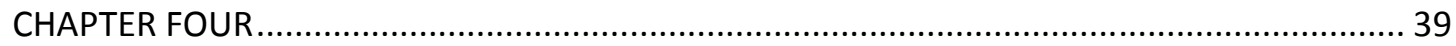

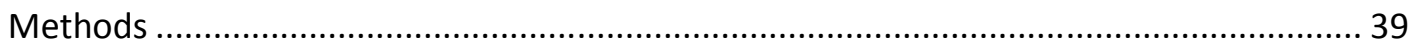

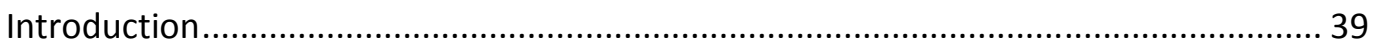

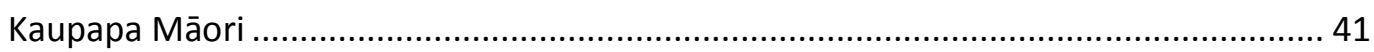

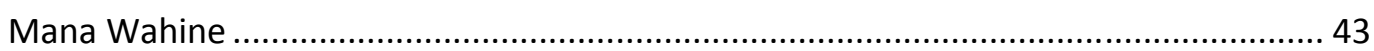

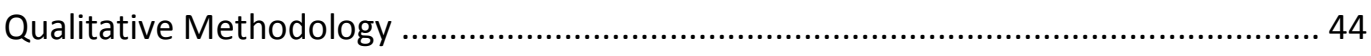

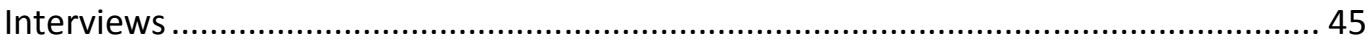

My Role as a Researcher ....................................................................... 46

Selecting the Participants ........................................................................... 48

Characteristics of the Participants.................................................................. 48

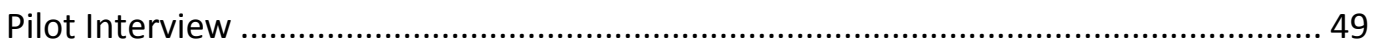

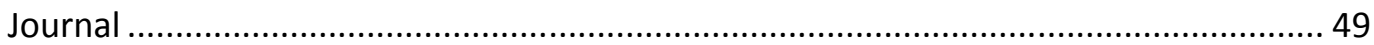

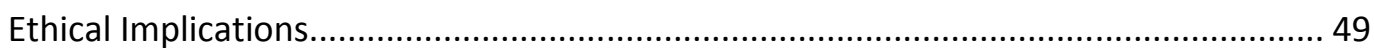

Interpreting the Research Information ........................................................... 50

Building on the Mana Wahine Conceptual Framework ........................................ 51

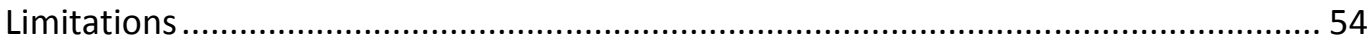

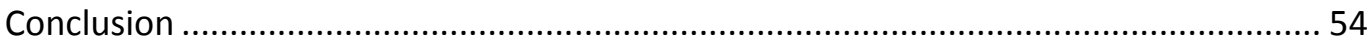

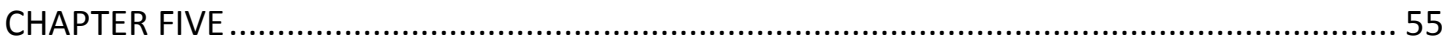

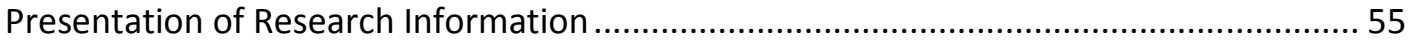

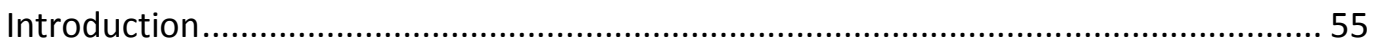

Interview Themes ................................................................................... 55

Development - contributing factors and overcoming barriers............................... 57

Māori Development - Māori culture, Tikanga and Te Reo ......................................... 60

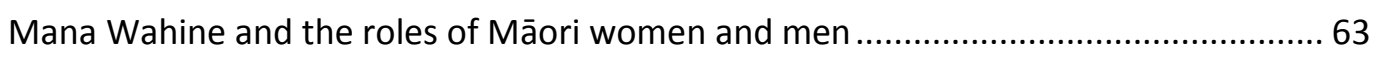

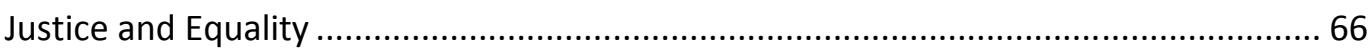




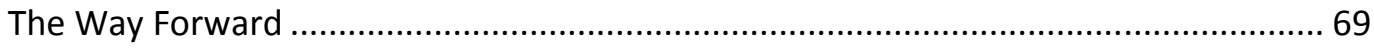

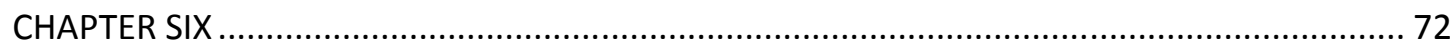

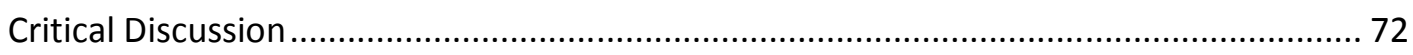

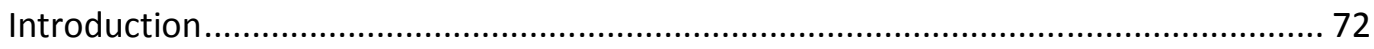

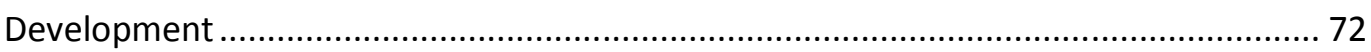

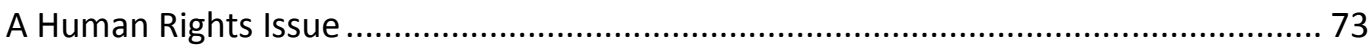

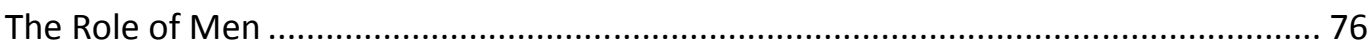

Māori Development …………………….................................................................... 77

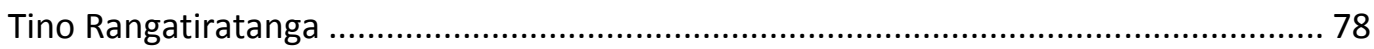

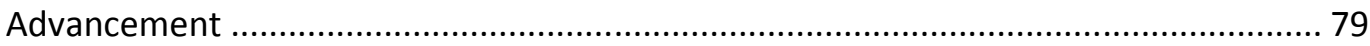

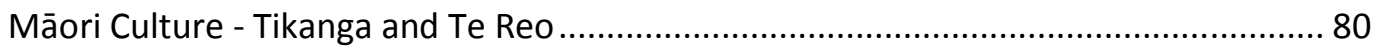

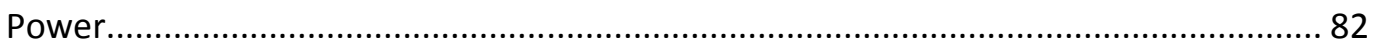

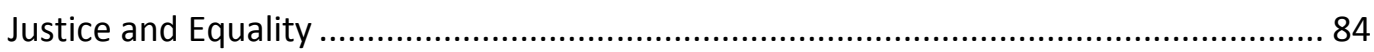

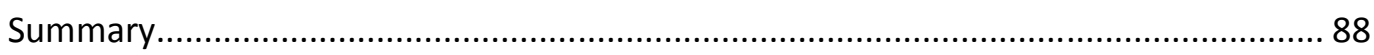

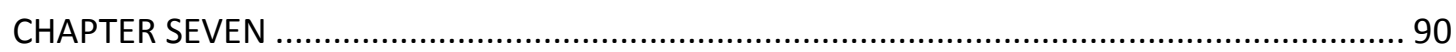

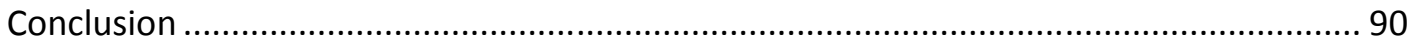

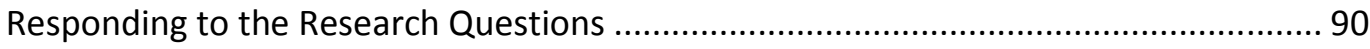

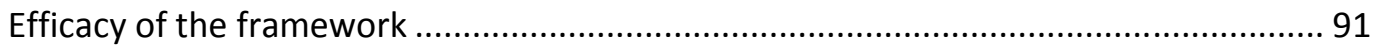

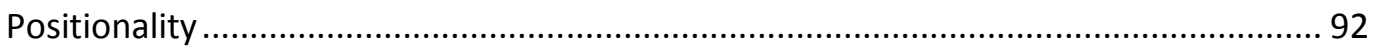

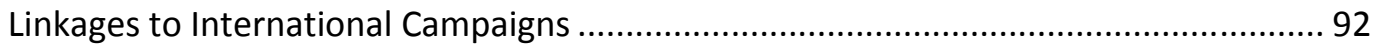

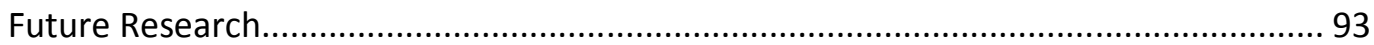

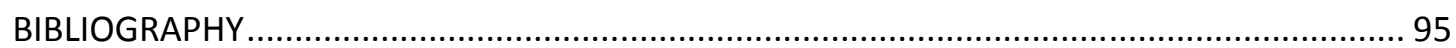

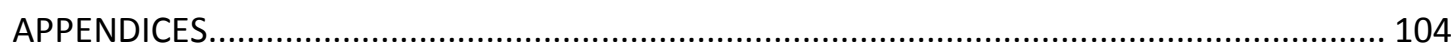

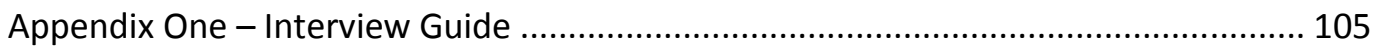

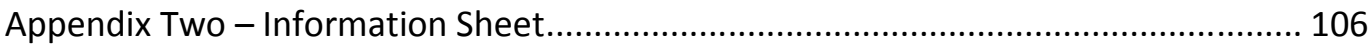

Appendix Three - Consent Form ............................................................................. 108 


\section{TABLES}

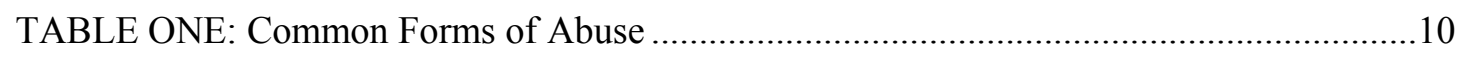

TABLE TWO: Ethnicity of Women and Children Using Refuge Services ..............................14

TABLE THREE: Demonstration of Guidelines for Māori Research........................................47 


\section{FIGURES}

FIGURE ONE: Research Framework.............................................40

FIGURE TWO: Mana Wahine Conceptual Framework....................................52 


\section{ACKNOWLEDGEMENTS}

Producing this thesis has been a group effort and I have been fortunate to have had guidance, support and encouragement from a number of wonderful people. I wish to express my thanks and gratitude to them.

The people who gave good guidance were my supervisors, Dr Jessica Hutchings and Sara Kindon. These talented women are very wise and together provided me with the perfect combination of challenge and stimulation to explore beyond the obvious and consider new possibilities. Thanks to them, this 'academic experience' for me has been an enjoyable one.

The people who kindly supported me with stories of encouragement and practical assistance were Te Raina Gunn, Parekotuku Moore, Angela Morris, Libby Nesus, Eruera Reedy, Jo-anne Taite and Hata Wilson. Their support is appreciated because it kept the mammoth task of completing this thesis to 'bite-sized' pieces.

The people closest to my heart - Patrick, Ezra and Phoebe were an oasis of support and encouragement and have 'propped me up' these past two years. The back-rubs, foot-massages and many a hot cup of tea in the early hours of the morning meant the 'marathons' in front of the computer were never too lonely or bleak.

To the fabulous women of Te Whare Rokiroki I extend my thanks and gratitude for letting me back into their lives and trusting me with their stories. I sincerely hope this thesis is useful in some small way.

The final word is a brief dedication. This thesis is about aspiration, commitment and determination. It is about hope for the future for Māori. All the children within my immediate and wider family carry our dreams and aspirations and I hope they embrace future opportunities to realise their potential and believe that anything is possible. I dedicate this thesis to them. 


\section{CHAPTER ONE}

\section{Introduction}

"Our tipuna had all the building blocks of a powerful future: confidence in themselves, their way of life, their dream and their right to fulfil it. Their generational daughters are trying to create the same thing" (Irihapeti Ramsden, 1994)

I am a Māori woman with a whakapapa (genealogical links) to Ngai Te Rangi and Ngati Kahungunu, and I am a student from the School of Geography, Environment and Earth Sciences (SGEES) working towards completing a Masters Degree in Development Studies. Demonstrating academic competence is my focus and priority. However, this thesis is also an opportunity to contribute to issues which I am most passionate: Māori development, the ways Māori women exercise their fundamental human rights and the many ways Māori women contribute to Māori development.

I am one of many who entered the Masters of Development Studies programme in the hope that improving knowledge about society would contribute in some small way to making the world a better place. I am looking for meaningful ways to: engage with Māori women research participants that is more than gathering information; participate in the research process in ways which legitimise my experiences and knowledge; and produce a piece of work that goes beyond being an intellectual endeavour and facilitates some measure of positive change.

\section{Research Aims}

This thesis explores the role of Mana Wahine in the development of a Refuge in Wellington. The aims are to:

- explore the meaning of Māori development in a Refuge environment;

- investigate the expression of Mana Wahine by Māori women Refuge advocates; and

- identify the extent to which Mana Wahine has influenced decolonisation.

The focal point to undertake this exploratory exercise is a women-based nongovernment organisation (NGO) - Te Whare Rokiroki Māori Women's Refuge (the 
Refuge). I have chosen to situate this thesis with the Refuge because it is a site for pro-Māori activism and resistance, which I believe are fundamental and vital ingredients for meaningful engagement with the aforementioned issues. From the outset, I wish to acknowledge with respect, the generosity of the women of the Refuge for contributing to this project.

\title{
Positioning Myself in the Research
}

Ki te taha o taku Matua

Ko Mauao te Maunga

Ko Tauranga Moana te Moana

Ko Ngai Te Rangi te Iwi

Ko Mataatua te Waka

Ko Romainohorangi te Marae

Ko Tahu Whakatiki te Tupuna

Ki te taha o taku Whaea

Ko Whakapunake te Maunga

Ko te Wairoa-Hopupu-Honengenenge-Matangirau te Awa

Ko Ngati Kahungunu te Iwi

Ko Takitimu te Waka

Ko Te Rauhina te Marae

Ko Te Rauhina te Tupuna

Ko Tairawhiti ahau

Tihei Mauri Ora!

\begin{abstract}
"If you are raised in a bleak environment of dysfunction where violence and abuse is normalised because it happens everyday in unimaginable ways, your right-of-passage to childhood is stripped away and you begin an intimate relationship with terror, pain and suffering. The loss is immense and the grief profound." (Identity with-held).
\end{abstract}

For nearly a decade I was employed with the Refuge as a Counsellor and Coordinator. During that time I worked with over 1000 whānau (families, comprising women and children) from around the motu (country). Working for the Refuge was not a job; it was a way of life because it was intense, demanding and challenging. The impact of supporting Māori women and children has been profoundly rewarding.

Some days I observed the hardships and suffering of Māori women and children because of violence perpetrated by partners, whānau and friends. Their resolve to seek out a safe environment for themselves and their children through Refuge was a testament to their strength and courage. And then there were days of much joy and celebration when new babies were born to women in the Whare (safe-house) or a 
woman found strength to say no to violence or children revelled in waiata (traditional songs) and haka (traditional war dance) performances. From these experiences, I learned that family violence in Māori whānau is neither inevitable or a predictable outcome and that positive change through breaking the cycle of violence can indeed become a reality. My fundamental belief is that whānau are the building blocks of society and the well-being of its members are central to the well-being of a community. I believe that only by getting involved with the Refuge and taking up the mantle of stopping violence is it possible to ensure the well-being of Māori women and children and contribute to their development.

A second motivating factor for joining the Refuge was the Māori women whom I worked with and came to know, respect and admire. Many of these women I now regard as sisters. Their hard work contributes to Māori and feminist agendas (Irwin 1990) and decolonising strategies (Smith 1999) which ultimately forge new pathways for Māori women.

I choose to do this research quite simply because I believe Māori women make significant and valuable contributions to the development of whānau, hapu, Iwi Māori and the wider community. This thesis is grounded in hope for the future and in a sense celebrates the successes of Refuge women - advocates and clients alike.

\section{Situating this Thesis within the School of Geography, Environment and Earth Sciences (SGEES)}

Development Studies seeks to understand the nature of development in a global context which takes into account:

"Political, economic, social and technological dimensions of change including issues of gender, culture, class, environment and conflict" (Graduate Prospectus, 2007:1).

The debates within this thesis are positioned in key development debates regarding gender and development and women's human rights. Violence against women is universal and present in all societies and cultures and has many forms and manifestations. In its report "Ending violence against women: From words to action" the United Nations (2006:132) asserts: 
"The forms of violence to which women are subjected and the ways in which they experience this violence are often shaped by the intersection of gender with other factors such as race, ethnicity, class, age, sexual orientation, disability, nationality, legal status, religion and culture. Therefore diverse strategies that take these intersecting factors into account are required in order to eradicate violence against all women."

The Refuge is an example of one organisation in New Zealand which dedicates its efforts to eradicating violence against all women. This thesis is positioned within the intersection of gender and ethnicity and in the chapters that follow, the issues that emerge are discussed.

Also discussed are the relationships and connections between the Refuge's strategies to stop violence against women and international development approaches ${ }^{1}$ which seek justice and equality for women, more particularly for their basic human rights and freedoms to be upheld. For example, the Millennium Development Goals ${ }^{2}$ and the Convention for the Elimination of Discrimination Against Women ${ }^{3}$ are just some of the mechanisms through which the intervention and prevention of violence against women is pursued.

Through making visible the rich and powerful stories of the women participants, it is hoped their experience, knowledge and wisdom regarding stopping violence and working with Māori whānau may at some stage be heard by development practitioners and policy makers. I note the following comments from the Secretary General of the United Nations (United Nations, 2006:7):

"The issue of violence against women came into prominence because of the grass-roots work of women's organisations and movements around the world. As women sought to gain equality and recognition of their rights in many areas, they drew attention to the fact that violence against women was not the result of random, individual acts of misconduct, but was deeply rooted in structural relationships of inequality between women and men."

I anticipate this research will be relevant to both Māori and mainstream development agencies and practitioners because it exposes masculinist patriarchal paradigms which

\footnotetext{
${ }^{1}$ I discuss these approaches in greater detail in Chapter 3 - Literature Review.

${ }^{2}$ Millennium Development Goals Fact Sheet. Retrieved 18 February 2008 from http://www.un.org/millenniumgoals

${ }^{3}$ Convention on the Elimination of All Forms of Discrimination against Women. Retrieved 18

February 2008 from http://www.un.org/womenwatch/daw/cedaw/.
} 
oppress and dominate Māori women. Understanding patriarchy, power constructs and cultural norms which discriminate against women are an important part of eliminating violence and upholding women's human rights moreover critical to positive and effective development.

\section{Insider Status}

From the outset, I declare my involvement as an 'insider' to this research (Smith 2000). I am not detached from the "objects of this theoretical investigation" (Collins, 1997:377) because I am a Māori woman who actively supports the stopping violence movement in New Zealand and I share a history with several participants by way of a former involvement with the Refuge. These experiences which are both cultural and political inform my position and standpoint, (Smith; 1999, Harding; 1997, Hartsock; 1983). My intellectual purpose as a scholar is to complete a Masters Degree in Development Studies. At the same time I wish to undertake this piece of work for other Māori women (Smith, 2006). That said, I do not assume for a moment that my experience is all that is required to complete this project. I agree with Smith (1999) that my approach to research as an 'insider' must be ethical, respectful, reflexive, critical and grounded in humility. In Chapter Four - Methods, I discuss implementing these ideas.

Smith (2006:7) also points out methodological risks inherent in 'insider' research as:

“... the potential for bias, lack of distance and lack of objectivity and...to mistake the research role with an advocacy role."

This statement reflects some of the exclusionary practices used to silence indigenous research and dismiss the challenges levelled at standard research practices which have been unhelpful or ineffective for Māori (Smith 1999). This thesis attempts to meet the criteria set by the academy to achieve a Masters Degree in Development Studies and contemporaneously contribute to the goals of Tino Rangatiratanga ${ }^{4}$ for Māori women. To meet these criteria, I have been continuously reflexive throughout the research and consciously worked to uphold my ethical and professional responsibilities as a researcher. The voices of Māori women are privileged and space has been created for their stories to be told.

\footnotetext{
${ }^{4}$ I refer to chieftainship and sovereignty in particular projects, agendas and movements that are led by Māori for Māori.
} 
The position I occupy as a researcher is a privileged, subjective one. In the process of completing research for this thesis, my reality as a Māori woman - that I was raised in the Kahungunu Rohe (area) and that I live and work in Wellington - will undoubtedly influence what I consider important and relevant. The stance adopted in this study is one which aligns with Kaupapa Māori research in that who I am and my experience and skills add value to this project. This expression maintains the validity and legitimacy of Māori knowledge and culture (Smith, 2000). To sum, I reject the idea of value free objectivity and neutrality and I agree entirely with Simmonds (2000 cited in Hutchings 2002:68) that: “... true objectivity is neither possible nor inherently valuable."

\section{Outline of Thesis}

This thesis comprises six chapters.

Chapter One - Introduction, outlines the aims and objectives of the research. I discuss the reasons for choosing this topic and my positionality and introduce the connections between theory and practice. In addition, I locate this thesis within the School of Development Studies and discuss some key development debates.

Chapter Two - Background, sets the scene for the Research. I present the herstory of the Refuge and the wider Refuge movement and I describe some of the issues relevant to a woman-based, feminist organisation. In addition, I outline the Refuge's guiding philosophies which influences how women and children are supported and shapes the way the Refuge is governed and managed.

Chapter Three is the Literature Review. To explore the role of Mana Wahine in the development of the Refuge, I have engaged with five key bodies of development literature thus:

- Development: to understand the spectrum and complexities of development at both theoretical and practical levels for local and international projects. This body of knowledge gave a back-drop against which development within the Refuge could be understood. I also discuss the significance of international 
development approaches especially those aimed at eliminating violence against women and gender equity.

- Indigenous Development: I discuss indigenous knowledge and consider the relationship and tensions between indigenous development projects and mainstream.

- Māori Development: here I engage with literature which explains why Māori development is important and how Māori-led agendas and projects which seek Tino Rangatiratanga are being achieved. In addition I engage with literature on Te Tiriti O Waitangi and the Mana Wahine claim.

- Mâori Women: the literature I draw on, presents traditional and contemporary ideas on the diverse roles of Māori women. Of particular note are the tensions between the strong, positive roles Māori women fulfilled in traditional societies which complemented Māori men. I discuss the changes which have occurred as a result of colonisation. In addition, I discuss the gender and development framework, radical feminism (which was significantly influential to early Refuge women who established the Refuge movement) and consciousness-raising groups. The concluding comments are focussed on the limitations of these theoretical perspectives.

- Mana Wahine: here I engage with literature to discuss the central tenets and highlight the connections to the work of the Refuge.

Chapter Four - Methods, is where I present the research framework which comprises: a Kaupapa Māori (Māori philosophy and principles) epistemology, Mana Wahine and Qualitative methodologies, and interviews. The limitations of this framework are noted and I conclude with a discussion on the Mana Wahine Conceptual Framework (Hutchings, 2000) which has been adopted to inform an analysis of the information generated in the research.

Chapter Five - Presentation of Research Information, is where I present information generated from the interviews. The main themes that emerged include practical experiences of development in the Refuge and contributing factors to successful development such as the expression of Māori culture, Tikanga and Te Reo. The participants' experiences of Mana Wahine are also presented. 
Chapter Six - Critical Discussion, brings together the findings of the literature review and the information generated through the research to critically discuss the issues which emerged and answer the research questions. I consider the ways participants challenge violence and abuse and ideologies and social constructs which oppress women and children. The focus is also on contestations of power and an on-going decolonising agenda which remains an essential part of a Mana Wahine analysis.

Chapter Seven - Conclusion, is where I re-cap the main points from the critical discussion and address the aims of the research. I also reflect on:

- the effectiveness of the methodological framework, what worked and areas for further development;

- my positionality in relation to this project;

- the Refuge's contributions to international development approaches and whether these approaches are suitable and effectively strengthen the Refuge's work; and

- identification of key issues and messages for the Refuge. 


\section{CHAPTER TWO}

\section{Background}

"Violence against women is perhaps the most shameful human rights violation. And it is perhaps the most pervasive. It knows no boundaries of geography, culture or wealth. As long as it continues, we cannot claim to be making real progress towards equality, development and peace”. (Kofi Annan, 2003)

\section{Introduction}

Family violence affects millions of women around the world irrespective of race, culture, socio-economic status, religion or educational background (Clearinghouse, 2006). In many societies, political, economic and social power has largely been the preserve of men (Robertson et al, 2007). Non-government organisations such as the Refuge are part of New Zealand's continuous effort to address this problem. The herstory of the Refuge demonstrates a commitment to stopping violence and challenging structures and ideologies, which dominate women. For Māori women this struggle is compounded because it also involves resisting patriarchal, racist and colonial attitudes and structures, which dominate and subjugate them.

From the beginning, the Refuge has established itself as a strong, woman-based organisation committed to stopping violence and abuse against Māori women and children. Amongst other things the focus of this thesis is development at flax-roots level coupled with the broader, global campaign to eliminate violence.

This chapter outlines the different forms of violence and presents the herstory of the Refuge. I discuss the emergence of the 'Parallel Development' policy and outline the organisation's vision, aims and objectives so that the reader may develop a deeper appreciation of the cultural, social and political contexts within which the Refuge operates. This chapter concludes with a discussion on the prevalence of family violence in New Zealand and the role of the Refuge in going forward to address it.

\section{The Nature of Family Violence}

Family violence flourishes in the privacy of the home. Overwhelmingly perpetrated by men against women, (Robertson et al, 2007) family violence is the most socially pervasive assault on women and children. Table One presents common forms of 
violence and abuse as identified by the National Collective of Independent Women's Refuges (NCIWR) ${ }^{5}$.

TABLE ONE: COMMON FORMS OF ABUSE

\begin{tabular}{|l|l|}
\hline Psychological violence & $\begin{array}{l}\text { Actions which make victims think they are crazy and } \\
\text { doubt themselves. Psychological violence is about } \\
\text { coercion, manipulation and control. For example, } \\
\text { playing mind games, smashing belongings, making } \\
\text { threats and stopping contact with friends and } \\
\text { whānau/family. }\end{array}$ \\
\hline Physical violence & $\begin{array}{l}\text { Physical assaults including punching, bashing, choking, } \\
\text { slapping and pinching. }\end{array}$ \\
\hline Sexual violence & $\begin{array}{l}\text { Rape, forcing sex, making unwanted sexual advances, } \\
\text { making someone feel guilty if they say no to sex, sexual } \\
\text { contact with a child under 16, performing sexual acts } \\
\text { against another person's will, hurting or making } \\
\text { someone feel ashamed. }\end{array}$ \\
\hline Economic violence & $\begin{array}{l}\text { Controlling the finances, making all the decisions about } \\
\text { how the money is spent, allocating an allowance that } \\
\text { doesn't cover the bills. }\end{array}$ \\
\hline Spiritual violence & $\begin{array}{l}\text { Stopping spiritual expression or religious beliefs, not } \\
\text { allowing attendance at church/ temple, putting down or } \\
\text { making fun of beliefs, traditions, or culture and } \\
\text { attacking wairua. }\end{array}$ \\
\hline
\end{tabular}

Source: National Collective of Independent Women's Refuges

\section{Herstory at a National Level}

The first Women's Refuge was established in 1974 from humble but strong beginnings ${ }^{6}$. The women involved belonged to a number of organisations based in Christchurch such as the Radical Feminists, University Feminists and Sisters for Homophile Equality (SHE) ${ }^{7}$. SHE was the first autonomous, political organisation for lesbian women and it developed analyses of patriarchy and heterosexism, which strongly influenced the way individual lesbian women viewed themselves (Te Awekotuku, 1991). These women believed they should have autonomy over their lives and enjoy social, economic and political equality with men (Grimshaw, 1987).

\footnotetext{
${ }^{5}$ Definitions and effects of violence accessed 18 January 2008 from http://www.womensrefuge.org.nz.

${ }^{6}$ Women's Refuge Herstory accessed on 15 December 2007 from http://www.womensrefuge.org.nz.

${ }^{7}$ Ibid.
} 
The central tenets of Radical Feminist ${ }^{8}$ thought which influenced these pioneer women $^{9}$ and can still be felt today include beliefs that:

- The gender/sex system was the fundamental cause of women's oppression (Tong 1998);

- Masculine and feminine identities are socially constructed (Rubin cited in Tong 1998); and

- Patriarchy ensures male supremacy and reinforces beliefs that women are inferior (Millet, cited in Tong, 1998).

Evidence or information regarding the involvement of Māori women in 1973 is limited however it is probable that Māori women contributed to the early development of the Refuge. In $1984^{10}$ Māori women raised their concerns at a National Annual General Meeting in Rotorua:

“... Wahine voiced their concerns about Women's Refuge not meeting the needs of Tangata Whenua. There was little space for Tangata Whenua to participate in the movement especially in decision making roles and there was no recognition of the fact that Tangata Whenua are the best people to provide support and advocacy for wahine and Tamariki. ${ }^{11,}$

As a result of this Hui the Parallel Development model emerged and NCIWR state ${ }^{12}$ :

"...this was not without controversy. This was a radical change for the movement: policies, values, structures and practices all had to be examined and changed. For Tauiwi, a huge shift was required for them to give over power, learn to operate under bicultural models, and continually challenge their own racism and lack of understanding of Tikanga Māori.”

In 1987 Te Whakaruruhau Māori Women's Refuge was established in the Waikato area as the first specialist Refuge for Māori women. Shortly after, Te Whare Rokiroki Māori Women's Refuge opened in Wellington. There are currently twelve specialist Refuges for Māori women operating around the country.

Māori women have struggled from the beginning to exercise their Tino Rangatiratanga to overcome racist attitudes and wrest power from Pākehā (European) women to locate and occupy a legitimate space in the Refuge movement. This thesis

\footnotetext{
${ }^{8}$ I discuss Radical Feminist theory in more depth in Chapter Three - Literature Review.

${ }^{9}$ Women's Refuge Herstory accessed on 15 December 2007 from http://www.womensrefuge.org.nz

${ }^{10}$ Ibid.

${ }^{11}$ Ibid.

12 Ibid.
} 
shows that similar issues are still being managed by Māori women and challenges to address racism and a lack of understanding of Tikanga Māori are ongoing.

To conclude, the following statement from NCIWR contextualises the strength of character, and courage required to challenge violence against women and establish the first Refuges.

"The Refuge movement was established in an environment that denied the reality of family violence. The general public did not welcome attempts to convince them otherwise. Women's Refuge advocates were considered 'marriage breakers' and perceived as 'men haters' and 'perverts who wanted to escape from men."13

\section{Herstory at a Local Level}

The first meeting to discuss establishing a Refuge for Māori women in Wellington took place in 1985. It took a further two years to set up the Refuge safe-house and enlist sufficient volunteer support to oversee and manage the organisation. The first Annual General Meeting for the Refuge took place in $1987^{14}$ where three women formally established a coordinating committee and made arrangements to:

- Fund staff positions and the delivery of Refuge services;

- Affiliate to the National Collective of Independent Women's Refuges (NCIWR); and

- Develop suitable governance and management structures including a Constitution. $^{15}$

\section{Vision and Objectives}

The Refuge is a woman-based organisation - run by women for the benefit of women and it actively promotes the visibility of lesbian women. ${ }^{16}$ It also seeks to empower all women and children so they have choices and can make the transition to independence. This is reflected in the following vision statement:

"Working towards safety for women and children in communities/Hapū by eliminating beliefs, attitudes and behaviours inherent in patriarchal structures which maintain and perpetuate violence."17

\footnotetext{
${ }^{13}$ Women's Refuge Herstory accessed on 15 December 2007 from http://www.womensrefuge.org.nz.

${ }^{14}$ Minutes of Te Whare Rokiroki's A.G.M. October 1985.

15 Ibid.

${ }^{16}$ Te Whare Rokiroki Māori Women’s Refuge Constitution 1990.

${ }^{17}$ Ibid.
} 
The objectives of the Refuge are to:

- assist Māori women (in the first instance) and their children who are victims of physical, emotional, mental and sexual abuse; to help women become aware of their alternatives to an abusive relationship; to provide emergency and temporary accommodation within Aotearoa/New Zealand;

- provide a refuge environment within Aotearoa/New Zealand which is culturally appropriate for Māori women and their children; and to

- provide within this environment a counselling and learning situation conducive to holistic healing based on Māori cultural values within Aotearoa New Zealand ${ }^{18}$.

To achieve these aims the Refuge provides emergency accommodation, assistance with legal and medical matters, referral to education programmes, contacts with Counsellors who understand the effects of violence and where necessary support dealing with other agencies. This support and assistance is provided in accordance with Māori cultural practices and beliefs where Tikanga (customs), Te Reo (Māori language) and Māori culture are observed as legitimate bodies of knowledge and ways of understanding the world that guide and shape the Refuge's practice.

In addition, the Refuge promotes public awareness of family violence and encourages recognition of the particular needs of women and children. The Refuge observes the principles of collectivism and equality ${ }^{19}$ where women are treated respectfully and discrimination is not tolerated.

\section{Parallel Development}

In 1986 Parallel Development was introduced to the Refuge movement and involved a shift of several key philosophies and policies towards:

- Tangata Whenua and Tauiwi (those who came after Māori) developing equally side by side;

- Sharing resources equitably ${ }^{20}$;

- Providing services which are complementary and culturally appropriate;

\footnotetext{
${ }^{18}$ Te Whare Rokiroki Māori Women's Refuge, "Key operating policies and procedures 2005"

${ }^{19}$ This thesis canvasses gender and indigenous issues and within this context equality means treating people respectfully.

${ }^{20}$ This thesis canvasses gender and indigenous issues and within this context equity takes into account the different needs of different groups. In addition, equity recognises that different approaches may be necessary to produce and/or achieve equitable and successful outcomes.
} 
- A system based on partnership that is consistent with Te Tiriti; and

- An organisational structure consistent with the feminist, women-based orientation of Women's Refuge ${ }^{21}$.

The new model underpinned several significant changes to the Refuge movement such as equal representation of Tangata Whenua and Tauiwi on the governing body of NCIWR and a commitment to Te Tiriti training for all members ${ }^{22}$. In addition, specialist Refuges such as Te Whare Rokiroki were identified as a critical component to meeting the needs and aspirations of Tangata Whenua. In line with Te Tiriti the Refuge gives expression to Tino Rangatiratanga in that it is an organisation run by Māori, for Māori based on Kaupapa Māori.

\section{Family Violence in New Zealand}

In 2006 the number of women and children using refuge services totalled 28,845 (16,738 women and 12,107 children) ${ }^{23}$. This figure represents a sharp increase of more than 10,000 over a five-year period. ${ }^{24}$ Table Two presents information regarding the ethnicity of women and children clients using Refuge services. It reveals Māori make up the greatest percentage of Refuges' clients.

TABLE TWO: ETHNICITY OF WOMEN AND CHILDREN USING REFUGE SERVICES

\section{ETHNICITY \\ $\%$ OF WOMEN \\ $\%$ OF CHILDREN}

\begin{tabular}{|l|l|l|}
\hline Māori & 42 & 51 \\
\hline Pākehā & 43 & 30 \\
\hline Pasifika & 8 & 6 \\
\hline Asian & 4 & 3 \\
\hline
\end{tabular}

Source: National Collective of Independent Women's Refuges

\footnotetext{
${ }^{21}$ Women's Refuge New Zealand (2006). About Women's Refuge. Retrieved 2 December 2007 from http://www.womensrefuge.org.nz/index.cfm

${ }^{22}$ Ibid.

${ }^{23}$ NCIWR July Statistics. Retrieved 2 December 2007 from

http://www.womensrefuge.org.nz/index.cfm

${ }^{24}$ Ibid.
} 
In 2005 the New Zealand police recorded over 60,000 offences involving family violence of which over 62,000 children and young people less than 17 years of age were present or involved. ${ }^{25}$ In the same year, 26 out of 53 cases, which resulted in murder, were related to family violence. ${ }^{26}$ Police statistics show an upward trend of emergency callouts to family violence incidents, with the number jumping from 24,700 callouts in $2002 / 2003$ to 30,692 in $2004 / 2005^{27}$. Robertson et al, (2007) present statistical information which is alarming. Since the enactment of the Domestic Violence Act 1995, over 212 women and children have died in domestic violence homicides.

These statistics are frightening and confirm that there are too many women and children victims of family violence and far too many Māori. Of greater concern is that the number of violent incidents is increasing and the severity of those incidents is worsening. One only has to think of the much publicised, tragic deaths of the country's most vulnerable taonga (treasures) Lillybing, James Whakaruru, Delcelia Whittaker and more recently the Kahui twins to conclude New Zealand is in crisis and the efforts of Government and arguably the wider community are woefully lacking.

To sum, this thesis argues that it is absolutely necessary for organisations like the Refuge and the work they do, to continue in communities around New Zealand. The efforts of the Refuge in collaboration with the Government, community and whānau members is an effective way, to achieve long-term "safety for women and children in communities/Hapū” (Refuge Constitution, 1990).

\footnotetext{
${ }^{25}$ New Zealand Family Violence Clearinghouse (2006). International domestic violence study released. Retrieved June 10, 2006, from http://www.nzfvc.org.nz/NewsItem.aspx?id=33. Cited in Freedom for Women Consultancy Team, MDEVE, 2006.

${ }^{26}$ Ibid

${ }^{27}$ Ibid.
} 


\section{CHAPTER THREE}

\section{Literature Review}

"Research is the gathering of knowledge-more usually, not for its own sake, but for its use within a variety of different applications. It is about control, resource allocation, information and equity. It is about power."(Ngahuia Te Awekotuku, 1991)

\section{Introduction}

Exploring the role of Mana Wahine in the development of the Refuge is the overall aim of this thesis. My approach to this literature review has been to consider the main ideas and corresponding sub-themes that make up the aim of the thesis. These are identified as:

- Development;

- Indigenous development ${ }^{28}$;

- Māori development;

- Māori Women; and

- Mana Wahine

This literature review begins with definitions and frameworks to understand the spectrum of development and some of the complexities including the distinctions between 'good' and 'negative' development. It is important to note that I am not trying to 'polarise' any discussion and therefore exclude other contributions, the goal here is to 'sieve' the multitude of definitions for development, identify the relevant issues and give meaning to development for Māori women.

As this thesis has a focus on social justice and inequalities that Māori women endure, I draw on literature relating to Gender and Development (GAD), radical feminism and consciousness-raising groups.. In addition, I situate local agendas within a broader campaign and discuss some international activities that attempt to address violence against women.

I draw on the experiences of first nation peoples in Canada to discuss the particularities of 'indigenous' development. The literature provides a backdrop to

\footnotetext{
${ }^{28}$ I have limited the scope of the review to first nation peoples in Canada because their colonised realities as indigenous peoples are similar to those experienced by Māori.
} 
understand how indigenous ways of viewing and understanding the world are central to the achievement of indigenous development goals.

The focus is sharpened to consider Māori development. Identification of contemporary and historical development projects highlights key factors that shape and guide the realisation of Māori aspirations. This includes the issues Māori have overcome to achieve their development goals.

In the final section I privilege literature from Māori women who wrote comprehensively about Mana Wahine. I defer to their expertise and wisdom. In addition I draw on Hutching's (2002) "Mana Wahine Conceptual Framework" to identify critical focus areas relevant to my research.

\section{Development}

There is no universally agreed definition of 'development' however Chambers (1997, cited in Thomas 2000:1) says development is about "good change", which implies some measure of benefit or improvement. That said, Cowen and Shenton (1996, cited in Thomas 2000:5) argue that this definition is inherently ambiguous. They allude to some of the complexities inherent in development projects and say:

"Development comes to be defined in a multiplicity of ways because there are a multiplicity of 'developers' who are entrusted with the task of development."

Thomas (2000) points out that 'development' can involve major change or it can be incremental; it can be fluid and continuous where improvements build on one another; it can affect how people think or view themselves and change may not always be positive. His next statement has particular relevance to indigenous peoples because it signposts issues of dominance and power and the extent of loss experience by indigenous peoples:

“... what some see as general improvement may have losers as well as winners and if social change is all encompassing and continuous then the implication is that previous ways of life may be swept away, with the loss of positive as well as negative features (ibid:2)."

Development projects are complex and involve many people with a range of agendas that may sometimes be hidden or in competition with one another. Thomas (2000:23) alludes to this dimension and asserts that development embodies "competing political 
aims, social values and contrasting theories of social change." He says development is about:

“...a vision or measure of a desirable society; an historical process of social change; and a deliberate effort at improvement by development agencies" (ibid:48).

Streeten (cited in Todaro, 2000:77) on the other hand states:

"Development must be redefined as an attack on the chief evils of the world today: malnutrition, disease, illiteracy, slums, unemployment and inequality. Measured in terms of aggregate growth rates, development has been a great success. But measured in terms of jobs, justice and the elimination of poverty, it has been a failure or only a partial success."

This thesis is less focussed on production or poverty in terms of living standards, rather on the realisation of human potential which is encapsulated in Korten's (1995, cited in Todaro 2000:77) 'people centred' view of development. He advocates the following principles:

- Justice: which involves ensuring a "decent human existence for all people"

- Sustainability: careful use of limited resources for future generations; and

- Inclusiveness: where people belong, contribute and participate in a family, community and wider society.

And finally, I refer to Woods (2005) whose ideas on development signpost the positive impact development processes can have to alleviate suffering or in the case of this thesis stop the trauma experienced by Māori women as a result of violence and abuse. He says:

"Development is a process of change which increases the opportunities or capabilities that people have while at the same time, reducing the absolute suffering they experience."

\section{International Development}

Violence against women is manifest in complex and diverse ways as women experience violence from before birth to old age in a wide range of settings. Eliminating violence against women requires a range of responses which are comprehensive, systematic and involve all stakeholders (United Nations, 2006). In September 2000 the United Nations General Assembly adopted the Millennium Development Goals (MDGs) ${ }^{29}$ and over 147 heads of state and governments signed

\footnotetext{
${ }^{29}$ Millennium Development Goals Fact Sheet. Retrieved 2 January 2008 from http://www.un.org/millenniumgoals
} 
up. As a framework to understand development, the MDGs attempt to address the serious issues faced by the poorest and most vulnerable sectors of societies and women and children make up a large proportion of those sectors. It reflects the commitment of leaders around the world thus:

"The MDGs range from halving extreme poverty to halting the spread of HIV/AIDS and providing universal primary education, all by the target date of 2015 - form a blueprint agreed to by all the world's countries and all the world's leading development institutions. They have galvanized unprecedented efforts to meet the needs of the world's poorest. ${ }^{30 \text {," }}$

However not everyone conceived the MDGs to be useful and valuable. Antrobus (2003) criticised the MDGs and questioned their validity. She argued that gaps existed in the MDGs such as violence against women and that Goal 3 - "[To] Promote gender equality and empower women" was particularly difficult to quantify. In 2006 as a result of campaigning from proponents like Antrobus, a new target involving universal access to reproduction health was introduced ${ }^{31}$. However violence against women remains absent from the MDGs which is surprising given it is a serious issue prevalent in societies around the world. United Nations Secretary General, Kofi Annan (2003) voiced his concerns as follows:

"Violence against women is perhaps the most shameful human rights violation. And it is perhaps the most pervasive. It knows no boundaries of geography, culture of wealth. As long as it continues, we cannot claim to be making real progress towards equality, development and peace."

My point here is to illustrate the linkages between the work undertaken by the Refuge to stop violence against women and children and international agendas to stop violence against women and children. A number of other international instruments strive to achieve the rights of women. These include:

- The Convention on the Rights of the Child (1989);

- The Convention Against Torture (1984);

- The Convention on the Elimination of All Forms of Discrimination Against Women (CEDAW);

- The Covenant on Economic, Social and Cultural Rights (1966); and

\footnotetext{
${ }^{30}$ Dev-Zone One pager Number 1, July 2007. Retrieved 14 December 2007 from www.devzone.org/mdgs/

${ }^{31}$ Ibid.
} 
- The Universal Declaration on Human Rights (1948). ${ }^{32}$

Of particular relevance to this thesis is the Convention on the Elimination of All Forms of Discrimination against Women (CEDAW). Viewed as an international bill of rights for women, CEDAW was adopted in 1979 by the United Nations General Assembly and signed by the New Zealand government in 1980. CEDAW is a treaty that has achieved global consensus and sets standards for women's human rights. As an international instrument it goes some way to addressing violence against women by elevating the issue to a global level and recognising violence as a breach of fundamental human rights. CEDAW (ibid) defines discrimination against women as:

“..any distinction, exclusion or restriction made on the basis of sex which has the effect or purpose of impairing or nullifying the recognition, enjoyment or exercise by women, irrespective of their marital status, on a basis of equality of men and women, of human rights and fundamental freedoms in the political, economic, social, cultural, civil or any other field."

All parties to CEDAW agree to take appropriate measures to ensure women exercise their human rights and basic freedoms. The New Zealand government is legally bound to put the provisions of CEDAW into practice and submit four-yearly reports on the steps taken to comply with their obligations. In July 2003 the Committee on the Elimination of Discrimination against Women met to consider New Zealand's Fifth Periodic Report (the Report) which noted a comprehensive range of activities led by the government to support the rights of women and improve participation and the ability of all women to exercise their rights through:

- Extensive consultation with women on content for the report and a "special effort" (ibid:2) to engage with a diverse range of women including Māori women, Pacific Island women, migrant and refugee women and disabled women;

- The introduction of a gender analysis for all papers submitted to the Government's Social Development Committee; and

- Te Rito - New Zealand's family violence prevention strategy and the CrimeReduction strategy aimed at reducing family violence, including child abuse and sexual violence.

\footnotetext{
${ }^{32}$ Creating a Culture of Non-Violence: The Report from the New Zealand Parliamentarians' Group on Population and Development 'Open Hearing into the Prevention of Violence Against Women and Children. Retrieved 10 December 2007 from www.fpaid.org.nz.
} 
The report (ibid) confirmed New Zealand's active engagement in activities to prevent and stop the occurrence of family violence. However, the rising statistics ${ }^{33}$ of violence against women and children and the much publicised family-violence-related deaths of many children are a sad indictment on New Zealand and draw into question the effectiveness of these activities. This thesis asserts New Zealand's effort to stop violence against women and the mindless deaths of so many children is woefully lacking and much, much more needs to be done.

\section{International approaches to address violence against women}

International approaches to eliminate violence against women have clear connections to local activities such as the work of the Refuge. In its report "Good practices" in combating and eliminating violence against women" the Division for the Advancement of Women (DAW, 2005) presents a global picture of the scale and prevalence of violence against women. The report (ibid: 2) notes a number of examples of current practice which suggest a measure of good and promising change ${ }^{35}$ thus:

"Governments have provided examples of good practices for combating and eliminating violence against women in their reports under the Convention on the Elimination of All Forms of Discrimination against Women... Nongovernmental organisations and entities of the United Nations system have also compiled examples of, and analysed, good practices in combating violence against women."

Next I draw several examples which demonstrate the range of diverse strategies which are currently being applied across the world to combat family violence ${ }^{36}$.

Integration and standardisation are priority areas:

- "The Women Against Violence Europe Network has development minimum standards for shelters; and

\footnotetext{
${ }^{33}$ A snapshot of statistical information in the section - Family Violence in New Zealand is presented in Chapter Two - Background.

${ }^{34}$ The report (DAW, 2005) urges caution when making such generalisations because of the suggestion these strategies and practices work for everyone all the time.

${ }^{35}$ It is important to note these examples are representative of practices which have emerged in particular contexts and are considered neither exhaustive nor universally applicable.

${ }^{36}$ The report is comprehensive and conceptualises violence against women on a continuum across a range a different dimensions. I have only selected examples of strategies that specifically address family violence.
} 
- Sexual assault services in Australia have established service standards" (ibid:7)

International laws are being reformed to create gender equality:

- "In many countries, including South Korea, Japan, Philippines and Taiwan, marital rape has been criminalised;

- In Pakistan, honour killing, which is the killing of women and girls for transgressing male honour, including through exercising their right in choice of partner, has been specifically criminalised;

- In India, women's groups and individuals are using Muslim marriage contract to assert women's right to property and divorce" (ibid: 15).

Legal codes are being designed to combat violence against women and address issues of safety and well-being to victims thus:

- "The United States federal Violence Against Women Act, 1994, contains provisions designed to reduce the frequency of violence against women, provide needed services to victims, hold perpetrators accountable, strengthen law enforcement, improve research and data collection and reform immigration law to help battered immigrant women escape their abusers;

- Many Latin American countries have enacted specific domestic violence laws... [which] include psychological violence in the definition of domestic violence" (ibid: 16)

In some countries increasing attention has been targeted to the rights of victims and protecting their dignity and integrity.

- "Turkey and Jordan have outlawed 'virginity test' that accompanied complaints of rape by young women;

- Finland, Sweden and Switzerland have enacted 'victim support laws' which entitle victims to free legal advice and representation, alongside access to other forms of advocacy and support; and

- Domestic violence legislation in South Africa, Austria and Malaysia requires victims to be informed of their rights under the law" (ibid: 19).

\section{Indigenous Development}

"An international movement of indigenous peoples has evolved because of shared experiences and common realities. It is based on claims to collective rights over self-determining autonomy that reject the conventional forms of 'Western' society-building associated with multiculturalism, individual rights, and universal equality" (Niezen 2003: 7 cited in Maaka and Fleras 2005).

Maaka and Fleras (2005:29) draw on the works of others (Peang-Meth; 2002, McIntosh; 2000, Maybury-Lewis; 1997, Stea and Wisner; 1984) to define indigenous peoples and present a perspective regarding current situations thus: 
“... 350 million indigenous peoples of the world, representing 5000 cultures and languages across more than 70 countries as living descendants of the original occupants of a territory. In structural terms, most indigenous peoples occupy the status of disempowered and dispossessed enclaves within a larger political entity. They are among the world's most underprivileged minorities under constant threat of cultural annihilation and physical destruction, largely because those states that claim authority over them also regard them as inferior, irrelevant or impossible."

Within this sphere of diversity it is not surprising that there is no single definition of indigenous peoples. Loomis (2000 cited in Maaka and Fleras 2005:30) notes additional complexities:

"Not all indigenous peoples have been conquered; not all nations are comprised of indigenous peoples; and not all indigenous peoples can be conceived as nations."

Durie (1998) agrees and says indigenous communities are not homogeneous despite many groups having similar physical and cultural characteristics. I concur with this statement given the participants in this research each have varied and diverse genealogical, cultural and political experiences.

Finally I refer to the definition used by the United Nations Working Group (Cobo 1987 cited in Maaka and Fleras 2005) and agree with Maaka and Fleras (2005:31) who exclude majority groups such as Pākehā (European) because as a group they are neither oppressed nor mobilised:

"Indigenous communities, peoples and nations are those which, having a historical continuity with pre-invasion and pre-colonial societies that developed on their territories, consider themselves distinct from other sectors of societies now prevailing in those territories, or parts of them. They form at present non-dominant sectors of society and are determined to preserve, develop, and transmit to future generations their ancestral territories, and their ethnic identity, as the basis of their continued existence as peoples, in accordance with their own cultural patterns, social institutions, and legal systems.”

\section{Development Aspirations}

At the heart of Indigenous development is knowledge or ways of knowing which according to Daes (1993, cited in Battiste 2005:5) comprise:

"all knowledge pertaining to a particular people and its territory, the nature or use of which has been transmitted from generation to generation." 
Battiste (2005) also says indigenous knowledge has always existed and intellectual activation by indigenous scholars, professionals and graduate students has resulted in challenges to the supremacy of Eurocentric theory, education, pedagogy and exposed its limited nature and prejudices. She says:

“... [indigenous] consciousness, language and identity [will] flourish without ethnocentric or racist interpretation (ibid:13)."

It is also useful to consider some of the needs, concerns and aspirations for indigenous peoples which Maaka and Fleras (2005) identify as: ${ }^{37}$

Decolonisation: self-determination through the elimination of colonial domination at a political, economic, social and cultural level (ibid: 36 );

Self-Determination: exercising control over their lives and land in "ways that reinforce and advance indigenous experiences, realities and aspirations" (ibid: $37)$;

Sovereignty: where indigenous peoples are sovereign mostly without formal recognition. "Legal sovereignty may be less important than the de-facto recognition of indigenous peoples as sovereign, with a corresponding right to be treated as such" (ibid);

Land: a top priority for indigenous peoples is control and ownership of land (ibid);

Respect for Difference: difference is what sets indigenous peoples apart and is central to their identity. On that basis, indigenous peoples want to be seen as part of society not excluded from it (ibid);

Culture: protection of culture and recognising cultural affiliations and the constructs of indigenous identity (ibid: 38 );

Peoples not problems: peoples with rights to self-determination rather than "doomed to extinction if they persist in their cultural ways" (ibid);

Rights not Needs: a shift from a needs to rights based framework with entitlements attached to address some of the social problems of indigenous communities (ibid); and

Treaty-based Constitutional Order: "a constitutional relationship that reflects, reinforces and advances treaty-based principles" (ibid: 39 ).

Indigenous aspirations are an important aspect of this thesis and are likely to emerge in the research. According to Walsh (1998) realising indigenous goals are best

\footnotetext{
${ }^{37}$ Variations to specific interpretation are also acknowledged.
} 
achieved by 'alternative pathways' and participatory development models. Walsh (1998:494) says 'people development' involves:

“...empowering people so that they can analyse their own situations and work for their improvement."

He also analyses indigenous research projects and offers one response to the ineffective strategies to address violence against women and children raised in the previous section. With an emphasis on participation and empowerment, Walsh (1998:494) draws on Edwards (1993) to argue:

"The role of participatory research is to maximise the range of ideas and information to which people have access, so that they can make their own decisions on the strongest possible foundation... good research can help people find a way through the daunting constraints imposed by poverty, inadequate resources, lousy infrastructure and an unresponsive government."

I agree with Walsh (ibid) that to be effective and meaningful participation is the essential ingredient for projects whether research or development activity based.

Maiava (2001) adds value here because as an indigenous woman from the Pacific Islands her perspective is based on lived reality. She offers a counter-position to mainstream development and encourages alternatives to Western frameworks of knowledge. She also advocates greater participation by indigenous communities to shape and determine their own future.

At this point I conclude the literature reinforces indigenous realities and ways of knowing. Next I discuss Māori Development ${ }^{38}$, the Mana Wahine Conceptual Framework and contributions from the Gender and Development literature. I draw on radical feminist thought to acknowledge its influence to the early pioneers of the Refuge movement and demonstrate its on-going influence today.

\section{Māori Development}

For Māori women in Refuge, Tikanga (customs and traditions), Te Reo Māori (Māori language) and Whānaungatanga (kinship, relationships) has a strong influence on the Refuge's ideologies, the delivery of services and the establishment and maintenance

\footnotetext{
${ }^{38}$ I acknowledge that Māori Development includes a broad range of issues, concerns and dimensions than those canvassed in this Thesis. Given the word constraints, only certain aspects of Māori Development are identified and discussed, which is not to suggest that other aspects are of less importance or relevance.
} 
of relationships. Tikanga, Te Reo and Whānaungatanga are principal mechanisms through which Māori development is achieved.

Māori development has multiple aims comprising: sovereignty, self-determination and the preservation of cultural identity, (Cram; 2005, Durie; 1998, Awatere-Huata; 1995, Walker; 1995, Reid; 1994, Henare; 1994, Irwin; 1992).

Durie (1998:457) argues self-determination is at the heart of Māori development and says it is:

“... practical and intimately bound to the aspirations and hopes within which contemporary Māori live. Essentially Māori self-determination is about the advancement of Māori people, as Māori, and the protection of the environment for future generations."

Durie (2003:3) sees Māori development as economic, social and cultural advancement which includes aspirations for greater autonomy, revitalisation of culture and language and a direct approach to delivering services to Māori. He points out the shift for Māori from state dependency to self-determination has necessitated the construction of new development frameworks to enable Māori aspirations to be "converted to practice."

Māori development is not contingent or dependant upon the receipt of Treaty settlement or Crown intervention which means that development does not occur only on receipt of state funding. Time and time again Māori demonstrate their resourcefulness and resilience to facilitate effective change (Smith; 1999, Durie; 1998, Irwin; 1994). Recent examples of successful Māori development include: Kura Kaupapa Māori (Māori language immersion schools); Te Kohanga Reo (Language Nests); and Wananga (Places of Higher Learning).

\section{Te Tiriti O Waitangi}

Te Tiriti impacts on Māori development. Māori culture is dynamic and forever changing. However from the mid-seventeenth century with the arrival of Pākehā, Māori were forced to confront colonialism and imperialism (Hoskins 1997). From first contact with Pākehā, immense and irrevocable changes to Māori ways of life and 
undisturbed sovereignty took place. The extent of change for Māori is captured by Hoskins (ibid:28) who said:

“... all of social structures have been colonised, distorted and rearranged and that the modes of colonisation (warfare, disease, law) and the imposition of a distinctly western hegemony, have meant the construction of 'new forms of social (including gender), economic and political relationships both within Māori culture and between Māori and Pākehā."

To manage many of the changes that occurred as a result of the huge influx of settlers, Mead (1999 cited in Cram 2005:62) asserts Te Tiriti was developed to:

“... articulate rights and responsibilities, regulate behaviours, and accommodate access rights of settlers without compromising the guardianship/ownership rights of Māori."

However, Jackson (1995:1) asserts te Tiriti has been used by Pākehā to justify dispossessing Māori of land and other resources and to exert superiority as a civilised, normal culture while viewing Māori culture as 'quaint' and 'spiritually-rich'. He says Te Tiriti was used to achieve:

“...the eventual dispossession of indigenous peoples with a minimum of cost and fuss. Apparent motives of colonial good faith have eventually been swept aside in the reality of colonial greed, and indigenous peoples have been left with documents rich in spirit but bereft of the actual meaning and understanding their ancestors had at the time of signing.

Cram (2005:51) agrees and says:

“...Māori worldviews and concerns are too often marginalised and our right to self-determination threatened. Such has been the case in this country even though our Tino Rangatiratanga is guaranteed within the Te Tiriti o Waitangi..."

Te Awekotuku (1994) argues that while there were two Treaty partners, only one has directly benefited - economically, socially and spiritually. She adds that until Māori benefit to the same extent as Pākehā, their position is one of disadvantage. Sykes (1994:15) agrees and considers the rights of Māori women:

"... the rights of Māori women guaranteed under the Treaty have never been addressed nor actively protected through legislation since 1840."

\section{Mana Wahine Claim}

According to Sykes (ibid: 16) preserving their rights influenced Māori women to lodge the "Mana Wahine" claim with the Waitangi Tribunal: 
"The essence of the claim is to bring to the forefront... the exclusionary practices that exist which inhibit and prevent participation by Māori women in the tribal models for self-determination, that have been erected under New Zealand legislation and the erosion that this is in itself has had on Te Mana Wahine in Te Ao Māori."

A member of the claimant group, Evans (1994b: 36) viewed those particular women as agents of change. She said:

"The claim is the first of its kind to be placed before the Tribunal. We reminded the Tribunal at the presentation that there was a perception among our women that the claims and settlement process and the Treaty debate had been captured by resource issues... the Tribunal needs to be mindful not to let the sex issues eclipse issues of status... the claim is more than just about Rangatiratanga, it goes to the heart of the matter of deconstructing the notion of Pākehā royalty and one chief, to a reconstruction of our own notion of Rangatira. The outcomes and remedies will no doubt be debated throughout and beyond the claim."

This action propelled the rights of Māori women directly into the political and public arenas and ensured the voices of Māori women would be heard. However Māori women must continue to wait because despite waiting over ten years, the Mana Wahine claim has not been heard by the Tribunal.

\section{Māori Women}

According to Mikaere (1994) women in traditional Māori society were an essential part of the collective whole, whakapapa and a key link between the past, present and future. The role of the Māori woman was just as important as the role of the Māori man and within Māori cosmology there were many powerful women. Jenkins (1986, cited in Mikaere 1994) identifies strong Māori women leaders such as Wairaka, Hinemoa and Rongomai-wahine whose qualities and influence can still be felt today.

Yates-Smith (1998) asserts atua wahine (female goddesses) in Māori cosmology had a powerful position in ancient rituals and traditions. Through oral sources such as karakia (prayer) and moteatea (traditional chants), Awatere (2000) identified many atua wahine who are still remembered today including:

- Papatuanuku - the Earth mother who is the giver and sustainer of life and through whom Māori women establish their identity as being the land itself;

- Hineteiwaiwa - the patroness of females who presides over the childbirth; 
- Hineauhuone - who brought the powers of growth and creativity, the first human form created from the male and heavenly element;

- Mahuika - the fire keeper; and

- Hine-nui-te-po - who stands at the gateway between this world and the next realm, and holds power over life and death.

It is clear that history ${ }^{39}$ is replete with stories about the strong, positive qualities of tupuna wahine (women ancestors). For example, Mikaere (1994:53) draws on Iwi (tribal) histories to describe the complementary roles of men and women:

“... Māori women occupied very important leadership positions in traditional society - positions of military, spiritual and political significance."

Prior to colonisation Māori women enjoyed a status and rank, equal yet different to men. They had a range of strengths and qualities not readily acknowledged in today's society but none-the-less fulfilled roles as exceptional leaders, positive role models, loving mothers and wise nurturers. I agree with Irwin (1990:84) who said:

"The way in which Māori women are treated and regarded in some contemporary settings bears no resemblance to the traditional Tikanga which are central to our cultural traditions."

Influences to Māori women's agendas are not limited to Māori history. In the next section I consider contributions from the Gender and Development (GAD) theoretical framework and discuss the importance of masculinist paradigms taking responsibility for stopping violence and changing behaviours and attitudes.

\section{Gender and Development}

According to Moore (1988:15, cited in Razavi and Miller 1995) Gender and Development:

"...dealt with the social constructions of men and women and how these constructions are reinforced by social activities that both define and are defined by them."

\footnotetext{
${ }^{39}$ I acknowledge the limited scope of the literature in that only written texts were consulted as part of this review.
} 
Thomson (2002) discusses gender stereotypes (Peterson et al, 1999) ${ }^{40}$ which begin the moment we are born and identified as either a boy or girl. She asserts 'labels' determine how we are treated, perceptions regarding the behaviour of males and females and even influences our view of the world. She argues that in most cultures masculinity is synonymous with aggression and bravery and draws on the works of Montoya (1998, cited in Thomson 2002) who raises gender-based violence as an issue of concern for development agencies. In his Nicaraguan study on preventing male violence Montoya (ibid:19) said:

"Violence is a common experience for males form a very early age and is one of the principal mechanisms for socialisation. In popular culture... it is considered one of the main dimensions of machoism..."

The United Nations International Research and Training Institute for the Advancement of Women (INSTRAW, 2004) encourages a more holistic and collaborative approach which envisions men as an important more of the solution to eliminate violence.

\section{Masculinist Paradigms}

INSTRAW (2004) asserts the elimination of gender-abuse requires a focus on men's responsibilities as the main perpetrators of violence and challenges existing masculinist paradigms and cultural norms. Local and international approaches call for change and require men from all walks of life to stop violence against women and children and construct new paradigms, (Duvvury and Nayak; 2003, Garda; 2001, Hayward; 2001, Manderson; 2001). The direct involvement of men within prevention and intervention strategies is a critical and necessary aspect of stopping violence against women and achieving gender equality as Hayward (2001:49) points out:

"Working alone, women are not likely to be able to end the gender violence against them because it originates in the structure of both men's and women's gender roles and relationships, and it is a mechanism to express and maintain that structure.

\footnotetext{
${ }^{40}$ I draw on the definition of stereotype from Peterson et al (1999) as: Stereotypes are pictures in our heads that filter how we 'see.' They are composite images that attribute-often incorrectly and always too generally-certain characteristics to whole groups of people. Thus, groups are seen as others want or expect to see them, not necessarily as they are. The oversimplification in stereotypes encourages us to ignore complexity and contradictions that might prompt us to challenge the status quo."
} 
New models of masculinity involve challenging gender stereotypes and assumptions which "... define men as superior, entitled to use force, and women as inferior, for whom violence is to be expected" (ibid:48). The challenge according to Manderson (2001:7) is to "identify ways to change the institutional, structural and personal environments that sustain a culture of masculinity." One example of facilitating change to masculinist cultures is to raise children in ways that are non-sexist and focus on equality (Hayward, 2001). Other examples include:

- White Ribbon Campaign (WRC) which is purported ${ }^{41}$ to be the largest effort in the world of men working to end violence against women. Each year on 25 November - the International Day for the Elimination of Violence against Women, men and boys wear white ribbons. This act represents a personal pledge to never commit, condone and stay silent about violence against women (United Nations, 2006). Since it began in Canada in 1991, the WRC has spread to over 50 countries around the world including New Zealand (ibid).

- In Mexico, the Colective de Hombres por Relaciones Iguialarias (CORIAC) works with men who are violent in the home and administers programmes which teach health personnel to understand issues of masculinity (Garda, 2001).

- In 2001 the New South Wales state government in Australia used prominent male athletes in its community education campaign - "Violence against women: it's against all the rules." The campaign targeted men aged between 21 to $29^{42}$.

- In New Zealand, NGOs such as the National Network of Stopping Violence Services (NNSVS) ${ }^{43}$ facilitates stopping violence programmes for men and challenges assumptions about violence behaviour, encouraging perpetrators to take responsibility for using violence.

\footnotetext{
${ }^{41}$ White Ribbon Campaign. Accessed on 23 February 2008 from http://www.whiteribbon.ca/about us/\#1.

${ }^{42}$ Violence Against Women Special Unit - 'It's all against the rule' state-wide campaign. Accessed 23 February 2008 from http://www.lawlink.nsw.gov.au/lawlink/vaw/ll_vaw.nsf/pages/vaw_vaw_iaatrcampaign

${ }^{43}$ Te Kupenga Whakaoti Mahi Patunga - The National Network of Stopping Violence Services (NZ). Accessed 13 January 2008 from http://www.nnsvs.org.nz/.
} 
Clearly, the struggle to transform gender relations and eliminate violence against women cannot be successful without the involvement of men.

\section{Radical Feminism}

The radical feminist movement emerged in the 1960s and 1970s from women's projects in the United States who perceived themselves as 'revolutionaries' motivated to improve the position of women Tong (1998). Radical feminists view the gender/sex system as the fundamental cause of women's oppression which according to Jagger and Rothenberg (cited in Tong 1998) is:

- $\quad$ widespread, existing in every society;

- $\quad$ the most difficult to change or remove;

- $\quad$ causes the most suffering to its victims and that suffering can go unrecognised;

- $\quad$ provides a theoretical framework for understanding other forms of oppression;

- women were historically the first oppressed group.

Rubin (cited in Tong, 1998:48) defines the sex/gender system as:

"A set of arrangements by which a society transforms biological sexuality into products of human activity."

She argues socially constructed ideas of masculine and feminine identities and behaviours ultimately serve to empower men and disempower women. She also exposes the patriarchal society as justifying its superiority and convincing itself of being 'natural' and that normality requires:

"one's ability to display the gender identities and behaviours society culturally links with one's biological sex" (ibid: 49).

The ideology of patriarchy was first developed by Millet (cited in Tong, 1998) who insisted the patriarchal sex/gender system was the root cause of women's oppression. She argued patriarchy serves men and ensures male supremacy and domination over women that perpetuates and reinforces beliefs of female inferiority through institutions such as the academy, the church and the family. Millet (cited in Bryson, 1999) also said these ideas became entrenched in society because they are linked to how people define being a man and a woman and express femininity and masculinity. She had this to say: 
"Men's power... goes deeper than the power based on class or race, and it is so universal, so ubiquitous and so complete that it appears 'natural' and, until named by feminists, invisible (ibid:27)."

These perspectives question how gendered identities are formed and high-light the pervasive social structures that oppress women and perpetuate unequal, rigid roles for men and women. The influence of the sex/gender system to this research is best captured by Tong (1998:49):

“...the way for women to dispel men's unjustified power over women is for both sexes first to recognise women are no more destined to be passive than men are destined to be active, and then to develop whatever combination of feminine and masculine traits best reflects their individually unique personalities."

\section{Consciousness-raising groups}

Radical feminist thought explains consciousness-raising as a means through which women may come together and express their negative personal emotional, sexual and family experiences and identify patterns of male power and abuse Bryson (1999). This thinking aligns the shared experiences and activities of women in groups such as the Refuge. Bryson (ibid) says it is necessary to identify the political implications and develop strategies for change thus:

"This new understanding gave rise to the key slogan 'the personal is political' and to the idea that all women could unite in a common sisterhood; it also provided the foundations for a theoretical analysis of male power which focused on the concept of patriarchy (ibid:27)."

The importance of non government organisations (NGOs) such as the Refuge in facilitating 'bottom up development' is discussed by Sen and Grown (1988:92 cited in Razavi and Miller 1995) who assert:

“...grassroots organisations focus on meeting women's needs relating not only to income but also health and education. Through this, they raise consciousness and engage in advocacy, legal struggles and political action."

They also discuss the ways 'bottom up development' occurs and note the critical role of NGOs in organising women for collective action. This view would be considered true for the Refuge whose political agenda's are achieved through collectivism and mobilising women to action. 


\section{Limitations}

Radical feminism has a particular focus on sex and gender as the fundamental cause of women's oppression. As such, it has limited scope for dealing with specific issues which are important to Māori women such as indigeneity, indigenous development and racism.

Gayle Leatherby (2003:46) points out there are many issues where men and women share a common interest. She says:

"Female oppression varies in both nature and degree... Women's lives are contradictory, with conflicting interest in different systems of power. Gender is only one source of power and for many women gender oppression has not been their primary concern."

hooks (1995:102) would definitely agree on that point. She asserts that there can be no feminist revolution until there is an end to racism and white supremacy. She urges revolutionary feminist thinkers to:

“... consistently challenge white power-feminism so that [black women's] radical agendas are not completely erased by those white women who continue to support racism and white supremacy."

In the New Zealand context, Hutching's (2005:50) salient point is noted. She warns against the realities of Māori women being defined by non-Māori thus:

"Traditional gender debates become problematic as their construction, location, and definition of Māori women occurs from non-Māori cultural values and understandings that disadvantage Māori women and the Mana Wahine movement."

I also note Hoskins (1997:38) who argues:

"Western feminist tradition has for a long time posited gender as the primary and universal site of oppression, while largely ignoring factors of class and race. This position to Māori women is untenable because it fails to expose/own/acknowledge not only white/Pākehā women as beneficiaries of Māori women's dispossession through colonisation, but also their continued implication in these relations in a 'post' colonial Aotearoa. Our status as tangata whenua, our culture and shared experience of colonisation (with Māori men) situates Māori women in a much larger reality than that of "women's rights."

Smith (1992) on the other hand says it is critical for Māori women to take control of interpreting our own lives and struggles. She does not dismiss feminist thought but points out that a theoretical framework that attempts to understand the realities of 
Māori women should include them, moreover contribute to their emancipation from racism, sexism, poverty and other oppressions (Hutchings, 2005).

Finally I look to Irwin (1990:82) who proposes a Māori feminist approach is:

“... pro-Māori, an integral part of Māori development and seeks to re-establish the Mana Wahine of our women, to allow us to stand tall beside the men in our whānau again. Not in front of them, the movement is not anti-men, nor behind them, we are not apologetic for our strength or our visions, but beside them, where our culture tells us we should be."

Thus far, I contend the concerns of Māori women extend beyond gender oppression and must include discussion, debate and further consideration of race and class. Understanding their unique realities and experiences requires a framework developed by Māori women for Māori women. To this end I look towards a Mana Wahine framework.

\section{Central Tenets of Mana Wahine}

To establish a strong, comprehensive basis for this research there are four definitions of Mana Wahine to which I refer.

Smith (1992) conceptualises four distinct and interconnected components:

- Whānau: the fundamental unit of identity and whakapapa (genealogy). Within Whānau structures such as Hapu (sub-tribe), Iwi (tribe) and Marae, Mana Wahine is struggled for and contested.

- Spiritual: Highlights the spiritual aspect of Māori women's realities and includes the role of historical female elements and the power of women to lift tapu (restrictions) and make things noa (common).

- State: Acknowledges the political and Pākehā-dominant structures which are at the core of Māori women's struggles. The colonial state constructed Māori women as a group that required domestication and redefined their roles primarily to facilitate contributions toward economic growth;

- Indigenous women: Locates Māori women's struggles within an international context and draws on the experiences and 'learnings' of other indigenous cultures. 
Evans (1994b:3) identifies self-determination as a critical component of a Mana Wahine framework thus:

"Mana Wahine signifies the process of self-determination by which we determine our social and cultural future and give effect to our status as tangata whenua - as Māori women... Mana Wahine denotes practices and procedures in exercise of self-determination which are peculiar to women..."

Awatere (2000:2) views Mana Wahine as steeped in traditional Māori culture:

"A divine fire which we innately possess as wahine. In the Māori language, "mana" is the "fire of the gods" [and] "wahine" is the "female space... Mana Wahine draws upon female divinities such as Papatuanuku."

And finally Hutchings (2005:48) says Mana Wahine is about intellect and part of a wider discourse:

"Mana Wahine is derived from Kaupapa Māori. It is the definition and application of kaupapa ${ }^{44}$ to situations and analysis by Māori women and challenges current colonial patriarchal ideologies and hegemonies ${ }^{45}$."

\section{Marginalisation and Mana Wahine as a site for resistance}

The metaphor of the margins explains much about social inequities, oppression, disadvantage and power struggles (Smith; 2006, Irwin; 1991). According to Hall et al (1994 cited in McIntosh, 2006:48) marginalisation is the "peripheralisation of individuals and groups from a dominant, central majority." Tucker (1990 cited in McIntosh, ibid:48) on the other hand says marginalisation is:

“... a process by means of which certain people and ideas are privileged over others at any given time... is centred in power relations; as power shifts any group can find itself ignored, trivialised, silenced, rendered invisible and made 'other'."

Many Māori live on the margins of 'mainstream' and Māori societies and experience exclusion is a myriad of ways, (Smith, C.; 2006, Cram; 2006, Ormond; 2006).

Linda Smith (2006:5) explains:

“... as an indigenous minority group Māori experience forms of marginalisation in relation to the dominant society and also acknowledges that as a society on the margins there are groups of Māori who are marginalised from Māori society and culture, some of whom may also be excluded from the

\footnotetext{
${ }^{44}$ In this context refers to a set of ideas.

${ }^{45}$ I refer to colonial patriarchal ideologies and hegemonies in other parts of this thesis. At these points I agree with Hutching's (2004) interpretation when the particular interests of a dominant culture maintain superiority and power over another culture.
} 
dominant society and many of whom may also experience multiple forms of marginalisation."

Hutching's (2002) Mana Wahine Conceptual Framework is a useful instrument to:

- respond to the marginalisation of Māori women; and

- at a practical level assist with the critical analysis of the data generated in the research.

This framework can also be considered a site for resistance against dominant colonial ideologies because it encourages a decolonising agenda which Hutchings (ibid:22) says:

“... moves towards a Tino Rangatiratanga reality for Māori, is developed by Māori for Māori and is fluid and dynamic in regards to what is includes and excludes at any point in time."

She urges others to work with the framework to ensure it is relevant and specific to their field. The critical focus areas she identifies assists with her analysis on Genetic Modification. This makes good sense and I have attempted to build on her work through identifying critical focus areas relevant to this field of study and developed questions to inform my analysis on the role of Mana Wahine in the development of the Refuge. I elaborate on the critical focus areas and questions later in Chapter Six Discussion.

\section{Summary}

Development is a complex process and although difficult to define is essentially about change, improvement and advancement. This thesis is concerned with 'people centred' development particularly for Māori women and children. The literature reflects common themes: that development projects should benefit all sectors of society, empower people to find their own solutions, mobilise them to action and alleviate suffering.

A number of international human rights frameworks have been developed to protect and preserve the fundamental rights and freedoms of women. Duvvury and Nayak (2003) contend violence against women is a clear violation of human rights and of critical important for positive development practice. They maintain "Development 
seeks to realise human rights and therefore must seek to eliminate gender inequality and expand choices" (ibd:45).

Indigenous development frameworks differ from mainstream because they are premised on indigenous ways of knowing and understanding the world. It is acknowledged that indigenous communities are not homogeneous and have certain aspirations which include: sovereignty, self-determination and protection of indigenous identities. This is certainly the case for Māori in the pursuit of Māori development agendas. Te Tiriti continues to have relevance to Māori and the Mana Wahine claim is the pursuit of political recognition of the rights of Māori women. Traditional Māori history shows Māori women fulfilled a number of roles which were central to the well-being of the whānau and they were never treated according to colonial notions of property and subordination. Quite the opposite was true and this is reflected in Māori cosmologies and whakapapa where there is strong evidence of women leaders, healers and strong, positive role models.

The GAD framework facilitates an in-depth understanding of the injustices and inequalities women have endured and the strategies and agendas undertaken to facilitate positive change. While radical feminism has been and still is significant to the Refuge, it is Irwin's (1990) Māori Feminist Perspective which speaks to the heart of the Refuge's philosophies. She advocates a pro-Māori approach to development, encourages a Mana Wahine ideology and validates the importance of Māori women in whānau. The rise in local and international approaches in working with men and masculinist paradigms strengthens the work of the Refuge and shifts the focus from beyond viewing men as part of the problem, but part of a range of solutions.

I have discussed literature on the Mana Wahine framework which includes recognition of Māori women as part of an indigenous culture living colonised realities; acknowledgement of Māori women's knowledge; the contemporary relevance of Te Tiriti; and the promotion of diversity (Hutchings 2002). With the literature reviewed, sufficient information has been brought together to guide the next steps of this thesis, which involves consolidating the research framework. 


\title{
CHAPTER FOUR
}

\author{
Methods \\ "Processes, procedures and consultation need to be correct \\ so that in the end everyone who is connected with the research project is enriched, \\ empowered, enlightened and glad to have been a part of it." (Mead, 2003)
}

\section{Introduction}

This chapter presents the research framework for this thesis. Similar to other Mana Wahine research (Hutchings; 2002, Pihama; 2001, Te Awekotuku; 1991) this research seeks Tino Rangatiratanga for Māori women and change to colonial ideologies which are discourses of dominance and oppression.

The aim of this thesis is to explore the role of Mana Wahine in the development of the Refuge which is achieved through two parts: the literature review which explores current thinking in fundamental areas and interviews with six Māori women participants. Both research methods have led to the identification of specific themes from which conclusions in relation to the research questions are drawn.

I am aware that this thesis must meet certain criteria set down by the academy to achieve a Masters Degree in Development Studies and it must appeal to an academic audience. Ethical research also has certain obligations attached such as reciprocity, trust, respect and representing the voices of the participants accurately and fairly (Te Awekotuku, 1991). Resolution of these issues led to the development of a research framework (refer Figure One) comprising; a Kaupapa Māori epistemology, Mana Wahine and Qualitative methodologies and interviews as the primary method. I have adopted Hutching's (2002) Mana Wahine Conceptual Framework because it is a suitable vehicle to analyse the information generated through the research. And finally I discuss my position as a researcher in relation to this project and the participants and the need to be continuously reflexive through the research process. 


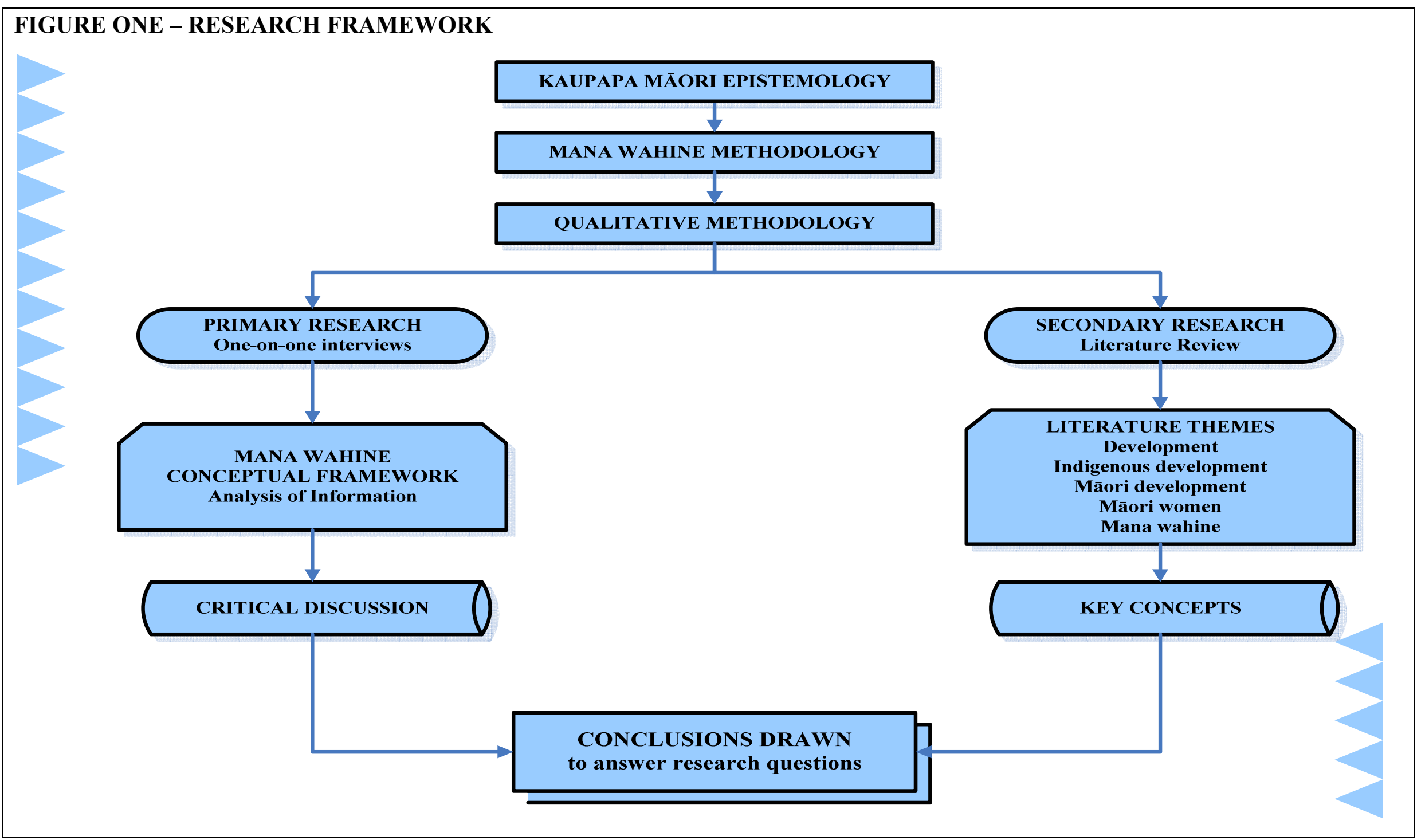




\section{Kaupapa Māori}

Epistemology is "a way of understanding and explaining how we know what we know" (Crotty 1998:3) and based on that understanding, Kaupapa Māori epistemology asserts Māori reclamation of their right to be Māori (Hutchings, 2002). I have chosen a Kaupapa Māori epistemology to drive this research because it is based on a Māori world view - 'Te Ao Marama' (Royal, 1998) which is similar to the aims of this thesis, the philosophical position of the Refuge and many of the views expressed by the research participants. To understand Kaupapa Māori and Te Ao Marama I refer to Hutchings (2002:59) who builds on the work of Royal (1998 cited in Hutchings 2002) thus:

- Rangatiratanga is concerned with leadership [which is defined] as the ability to bind (ranga) groups (tira) together;

- Manaakitanga points to the mutual elevation of mana in an encounter scenario;

- Whānaungatanga denotes the interconnectedness of all things and this is shown as whakapapa...;

- Tohungatanga concerns expertise and skill, particularly with symbolism, and the interpretation and creation of new symbols and the preservation of old symbols;

- Ukaipo are those places where one is nourished. These places are likened to a mother's breast;

- Kotahitanga denotes the unity of all things in the world. The experience of separateness, duality and alienation in the world is a foreground to a much deeper plane of existence whose major feature is Kotahitanga.

Bishop (1999) asserts that Kaupapa Māori epistemology challenges the locus of power in terms of research issues and the dominance of traditional individualistic research. Pihama et al (2002:38) agrees and defines Kaupapa Māori research as "Māori desires to affirm Māori cultural philosophies and practices" whereas Smith (1995) says Kaupapa Māori research involves research by Māori, for Māori and with Māori. Thus, there is a strong alignment with this epistemology and the Refuge's operational policy - Parallel Development which reinforces a Kaupapa Māori framework as the basis to undertake this research.

Smith (1990 cited in Hutchings 2002:57) asserts:

“A kaupapa Māori base is local theoretical positioning related to being Māori; [which] pre-supposes that:

- The validity and legitimacy of Māori is taken for granted;

- The survival and revival of Māori language and culture is imperative; 
- The struggles for autonomy over our own cultural well-being and over our own lives is vital to Māori survival."

Kaupapa Māori is more than an epistemology or research method (Hutchings, 2002) it embraces traditional beliefs and ethics, while incorporating contemporary resistance strategies that embody the drive for Tino Rangatiratanga for Māori. (Henry and Pene, 2001). Irwin (1994) points out that Kaupapa Māori research is one which is culturally safe and involves mentorship from Kaumatua, is culturally relevant and appropriate, satisfies the rigour of research and is undertaken by Māori.

Cram et al. (2004:17) asserts Kaupapa Māori research:

"... is set within a historical context and addresses the oppression of Māori in their own land and breaches of the Treaty of Waitangi and guarantees of Tino Rangatiratanga."

Similar to other proponents (Hutchings; 2002, Smith; 1999, Irwin; 1992b, Te Awekotuku; 1991, Irwin; 1990), Cram et al (2004) maintain Kaupapa Māori research is an attempt to retrieve space for Māori voices and perspectives, whereby Māori realities are legitimate. This is an important point given the focus of this research is to present the stories of six participants in ways that honour their realities and legitimise their experiences.

The strength of a Kaupapa Māori epistemology for this study is in its cultural relevance to both Māori researchers and participants. Kaupapa Māori research with Māori will undoubtedly require engaging with issues that are important and relevant to Māori such as culture, Te Reo, Tikanga, colonisation and Te Tiriti. Similar themes will inevitably emerge in this research because as Smith (1999:191) says:

"Kaupapa Māori research is a social project; it weaves in and out of Māori cultural beliefs and values, Western ways of knowing, Māori histories and experiences under colonialism."

Pihama (2005:192) agrees and says Kaupapa Māori theory is:

“... an indigenous theoretical framework that challenges the oppressive social order within which Māori people are currently located and does so from a distinctive Māori cultural base".

Cram (1997) says positive research with Māori needs to be collaborative, empowering and reflexive. Through careful planning of the research process and guidance from 
my Supervisors the Refuge advocates were profiled and their stories made visible so that the information generated was useful. My hope was that the final research products would benefit them individually and collectively by providing insight on current issues and tensions and inform future Refuge agendas. Finally, I refer to Pihama (2001) who says:

"The transformation or emancipator intent of Kaupapa Māori theory may be viewed as a decolonisation process; however it is not solely about the theorising for transformation but is also directly related to the development of practical interventions."

The Refuge, the services it provides, its philosophical position and active stance against the oppression of Māori women and children is an example of a practical intervention.

I have adopted two methodological approaches - Mana Wahine and Qualitative methodologies because of the complementary nature and high degree of compatibility between the two. In addition both methodologies fit within a Kaupapa Māori epistemology which I discuss next.

\section{Mana Wahine}

Te Awekotuku (1992:50) considers the aims of Mana Wahine research to be:

1. The heritage and herstory of Māori women whose worldviews have formed the basis of most, if not all, recorded cultural knowledge;

2. About exploring the nature of the differences between Māori men and Māori women from other female perspectives, which stimulates discussion, offers new insights and challenges, and focuses on a relatively unstudied part of this country's indigenous culture;

3. Contributing to what is currently a very thin, shallow and fragile body of knowledge, by research, publication and the focused development of a strong and exciting new discipline; and

4. To return to wahine Māori what they have been denied. To rediscover what has been lost or mislaid. To uncover what has been spoiled or misinterpreted.

Pihama (2001) writes comprehensively about Mana Wahine and brings together various ways Māori women talk about theory to identify and articulate those elements which make up Mana Wahine theories. In this regard, Irwin (1992b:5) contends that it is up to Māori women to determine our own theories thus: 
"We don't need anyone else developing the tools which will help us to come to terms with who we are. We can and will do this work. Real power lies with those who design the tools - it always has. This power is ours. Through the process of developing such theories we will contribute to our empowerment as Māori women, moving forward in our struggles for our people, our lands, our world, ourselves,"

A fundamental tenet of Mana Wahine is that the roles of tupuna wahine were very important in Māori society and in contemporary contexts demands the recognition of these roles in all their variety and diversity. Pihama (2001:234) says Mana Wahine theory has its origins in ancient knowledge and asserts:

"What we as Māori women are having to do in our present context is reassert our positions and status within our communities as well as wider society. The status of Māori women has been seriously misrepresented. It is important that Māori women take control of spaces where our stories can be told. This includes theoretical space. Our voices have been silences for too long. The silencing of Māori women's voices has meant the silencing of our theories, worldviews."

The points being made here are that Māori women's knowledge, experience and stories are important and valuable. As Hutchings (2002:67) says:

"A Mana Wahine research approach strives to create relationships and understandings of the status of Māori women that are relevant to Māori culture, and to effect change as a result."

I also draw on a qualitative methodological approach which on face value, may appear inconsistent with the proposed research approach because it is predominantly western-defined (Tolich and Davidson, 1999). The value added in this instance is the ability to "... look at something holistically and comprehensively, to study it in its complexity, and to understand it in its context" (Punch 1998 cited in Hutchings, 2002). The choice of a qualitative methodology is also based on a desire to understand the individual realities of each research participant and appreciate the diverse herstories and interpretations that will inevitably emerge.

\section{Qualitative Methodology}

Qualitative methodology is defined as:

“... multi-method in focus, involving an interpretive naturalistic approach to its subject matter...qualitative researchers study things in their natural settings attempting to make sense of, or interpret, phenomena in terms of the meanings people bring to them" (Denzin and Lincoln 1994 cited in Clandinin, 2007:2) 
Despite the superficiality of the research 'relationship' qualitative research enables researchers to build rapport and get to know research participants. (Tolich and Davidson, 1999). The advantages of utilising this method were that I could provide explanations of terms, seek clarification and the participants could explain their views as much or as little as they liked.

Tolich and Davidson (1999:184) confirm qualitative research is one where I can be involved, not distant and independent. They assert: “...we are always part of what we study. There is no getting away from this fact." A qualitative approach acknowledges the multiple realities of people that exist in any given situation. There are a range of different realities present in this study which should be taken into account; the research participants, their Māori women and children clients, mine, my supervisors as well as any readers of this thesis. Robinson (1998:409) asserts:

"Qualitative techniques are essentially descriptions of people's representations and constructions of what is occurring in their world."

\section{Interviews}

One-on-one, semi-structured, open, in-depth interviews are appropriate and effective qualitative methods through which it is possible to make visible the voices of the six women participants, generate information and answer the research questions. Patton (2002:161) says: “...the purpose of interviewing is to access the perspective of the person being interviewed." Interviews enables a process of 'talking back' which hooks (1989) defines as:

"The creation of space for authentic dialogue which enables the marginal invisible, inaudible voice to be heard."

I have drawn on Yow's (2005) work and summarised the strengths of interviews thus:

- I can ask questions, probe and clarify meaning which is especially important should I need or want to know underlying reasons for decisions;

- Interviews reveal day-to-day activities, much of which is not on public record and not readily available to a wider audience;

- Interviews can show the nature of relationships that characterise groups and reveal various aspects of life within communities; and

- Interviews can give meaning to the images and symbols people use to express themselves. 
Patton (2002) says feelings, thoughts and intentions cannot be observed and as a result it may be difficult to grasp how people understand the world and the meanings they attach to what goes on in it. I contend interviews will provide a way to probe for information on those things that cannot be observed in a typed format, understand meanings and gain insight into the realities and lived experiences of the participants.

I anticipated that each interview would take between 40-60 minutes however the reality was 1-1.5 hours. There was one occasion when a participant asked for a second interview as she wanted to discuss additional ideas she considered important. I conducted all interviews in Wellington during June and July 2007 and returned a copy of the transcript to each participant to check for accuracy and confirm that they were comfortable for their comments to be used. Hutching (2004) asserts this is an integral part of the interview process because it gives the narrator an opportunity to correct mistakes and reconsider their narrative after seeing their words typed. I transcribed each participant's words including the 'ums' and 'ers', laughter and pauses because how dialogue occurs may be important too (Tolich and Davidson 1999).

\section{My Role as a Researcher}

As a novice researcher, it has been important to consider what it actually means to behave ethically. To this end, I have drawn on Te Awekotuku's (1991) framework for ethical conduct for researchers which sets out principles based on the protection of rights, interests and sensitivities of the people being studied. I have built on these ideas and in Table Three present examples which demonstrate how these principles were implemented in the research. 
TABLE THREE: DEMONSTRATION OF GUIDELINES FOR MĀORI RESEARCH

PRINCIPLE

IMPLEMENTATION of PRINCIPLES IN RESEARCH

Aroha ki te Tangata - respect for all people by allowing people to

define their own space and meet their own terms.

He Kanohi kitea - acknowledges the importance of meeting face to

face.

Titiro, whakaronga ... korero - highlights the importance of looking

and listening and knowing when it is appropriate to speak. It involves demonstrating respect for the opinions, ideas and knowledge of others.

Manaaki ki te tangata - refers to a collaborative approach and reciprocity which involves giving back to the community involved in the research.

Kia Ngakau Mahaki - demonstrating humility in the approach to research and knowledge and qualifications to benefit the community.

Kaua te takahia o te mana o te tangata - not trampling on the

mana of people. Instead uphold the dignity and integrity of people. Sound out ideas,

disseminate research and provide feedback that keeps people informed.
- Participants' choice of anonymity was respected.

- All interviews were conducted subject to availability of participants and their preferred venue.

- Only face to face interviews occurred and on one occasion a second interview was conducted to ensure a participant's view was fully represented.

- The participants were given sufficient time to explain their ideas and perspectives.

- Influencing the participants' perspective was closely monitored.

- Some aspects of the research have been collaborative in nature

- A bound copy of this thesis will be presented to the Refuge.

- Acknowledgement of the knowledge of participants.

- Using my knowledge to develop an instrument which contributes to the decolonising agenda and makes visible the voices of women and children.

- $\quad$ Participants informed of research process and contact maintained particularly when seeking consent to use information.

- Privileging information has been treated with caution to uphold the integrity of the stories entrusted to me.

- Ethical boundaries of research were fully explained to all participants. 


\section{Selecting the Participants}

As the focus of this research is the role of Mana Wahine in the development of the Refuge it was expected that the participants would be former and current Refuge advocates. The snowballing technique (Cohen and Manion, 1980) was used to source participants for this study. I used my network of Refuge women to develop a small list of potential participants who in turn identified other potential participants who agreed to take part in this study.

\section{Characteristics of the Participants}

The participant group was made up of six Māori women who were or still are paid or volunteer workers for the Refuge. On average their length of service to the Refuge was five years with the shortest term being one year for one participant and the longest being 18 years each for two participants. The combined length of service between all six participants was 61 years which they viewed as testament to their commitment to the work of the Refuge. The participants varied in ages from 21 to over 60 and whakapapa to a number of Iwi (tribes). Four out of the six participants were happy to be identified and their comments attributed to them while two participants chose to remain anonymous. With the exception of the latter two participants, the other participants consented to being identified by name and iwi affiliation. As a group, the participants have a diverse range of backgrounds and life experiences that contribute to and inform their perspectives. Amongst other things, they have important roles as mothers, grandmothers, aunts, wives, lovers, managers, poets, actors, academics and health professionals.

In consultation with the current collective, three key 'development markers' or 'milestones' in the Refuge's herstory were identified as the 'lens' through which the research question could be explored. The milestones occurred within a ten-year timeframe and throughout the interviews were referred to as 'herstorical points' and comprise:

- the establishment of the community based support centre;

- a time when the collective had a membership of more than eight women; and

- a time when the collective had a membership fewer than eight women. 
At the 'herstorical points' each woman was specifically asked to participate in this research because of the nature of the role she had at that time. This meant an element of consistency in the process could be introduced so that at each 'herstorical point', one paid worker and one volunteer would be interviewed.

\section{Pilot Interview}

Before conducting the main interviews it was agreed with my Supervisors to conduct a pilot interview. This was an opportunity to refine my approach and address issues such as ambiguity and repetitiveness. The pilot interview was conducted with a Māori woman with previous research experience and a working knowledge of Refuge. She agreed to participate and give feedback to the interview process, my manner, and specific feedback to the research tools I had developed such as the Information Sheet, Interview Guide and research questions. As a result of her feedback I made several adjustments to the order of questions and clarified the meaning of about six terms.

\section{Journal}

I also kept a journal to map progress during the research. This was my space to be reflexive, consider the participants and note the thoughts and feelings that emerged during the interview. It was the instrument for testing assumptions, noting improvements or adjustments for future interviews and it was where I captured significant issues for discussion with my Supervisors. This was useful and as a result I was able to resolve an issue around confidentiality.

\section{Ethical Implications}

Josselson (2007:537) asserts:

"...ethical practice and ethical codes rest on the principles of assuring the free consent of participants to participate, guarding the confidentiality of the material, and protecting participants from any harm that may ensue from their participation."

Ethical approval for this research was granted by the Victoria University Wellington Human Ethics Committee. The application addressed:

- Informed consent; by defining what this means and the likely effects for participants. I noted Josselson (2007) who draws on the works of Ely (1991) and Estroff (1995) to alert researchers to consider vulnerabilities and the consequences that participants might not recognise at first even when they give their consent. I took this matter into account and built two opportunities into the process whereby 
the participants could consider the impacts of their participation. First by approving their individual transcripts and secondly by approving Chapter Five Presentation of Information.

- Confidentiality - in the first instance participants were identified in the research and their comments attributed to them. This approach draws on Kaupapa Māori epistemology which is concerned with social justice and positive change for Māori women and an over-aching goal of realising - Tino Rangatiratanga. However, participants were also given the option to remain anonymous and could choose a nickname or pseudonym. That said, it is useful to draw on Hall's (2004) ideas of potential barriers to effectively manage confidentiality in research. She argues complete concealment of identities through using pseudonyms is probably impossible and in a country as small as New Zealand, moreover in smaller Māori communities where everyone knows everyone else, confidentiality may not be easy to preserve.

And finally on the issue of ethics and ethical research it is Te Awekotuku's (1991) principles: "Responsibility to the Iwi Studied" that I turn to for guidance. Tolich and Davidson (1999:93) assert these principles: "acknowledge and challenge a tradition of 'intellectual colonialism' [and] alert every researcher to issues of partnership and accountability".

\section{Interpreting the Research Information}

The information in this research is presented as largely unedited transcripts although minor adjustments have been made only to support the 'readability' of the text. To a greater extent, the transcript for each participant has been left in its entirety. All participants were consulted and given two opportunities to review, provide feedback and where necessary make changes to how they were quoted and represented in the study. Confirmation from participants contributes to authentic representation (hooks 1989) and ensures they are completely satisfied with all comments made. Their narratives are presented fully in Chapter Five - Presentation of Research Information which also contributes to authentic representation (ibid). 
The interviews generated a mountain of information which required a rigorous system to manage the paperwork efficiently and an effective means to understand the information so that it could be discussed. To this end, I relied on coding methods to assist me to interpret the information and develop themes. Tolich and Davidson (1999:140) describe coding as:

"The process of categorising and sorting data. Codes serve as short-hand devices to label, separate and organise data. By providing the pivotal link between the data collection and its conceptual rendering, coding becomes the fundamental means of developing analysis."

I transcribed the interviews and through the identification of common themes I was able to identify similarities, points of difference and inferences in the participants' experiences and perceptions. I followed Hutchings (2002:76) example of interpreting information which she asserts:

"Through the identification of metaphors and images used by the research participants I searched for assumptions that were underlying such statements or inferences. I also searched for what was not being said or was marginalised, obscured or made invisible by different participants."

Positive and negative coding was used to identify themes which Tolich and Davidson (1999:141) describe as:

“...a means to record areas of theoretical and empirical interest... words of praise, encouragement... areas of weakness... further clarity or new questions can be asked."

\section{Building on the Mana Wahine Conceptual Framework}

I have drawn on Hutching's (2002) Mana Wahine Conceptual Framework (the framework) because it enables the identification of critical focus areas and corresponding questions to inform an analysis. The framework is presented in Figure Two together with a brief narrative to explain its meaning. 


\section{FIGURE TWO - MANA WAHINE CONCEPTUAL FRAMEWORK}

The framework is represented by the Harakeke (flax) which emerges from Papatuanuku and is positioned within Te Taiao (the environment). Hutchings (2002:144) describes the framework as:

"The roots represent the foundation, continual life essence and energy of the conceptual framework and are defined as whakapapa, kaupapa Māori and Māori women. The framework weaves with the dimensions of: Māori women, kaupapa Māori and the cosmological order of whakapapa. The various dimensions inform the mana wahine analysis. The nature and interpretation of these dimensions is fluid and dynamic and can vary among those telling stories within the framework."

TE TAIAO

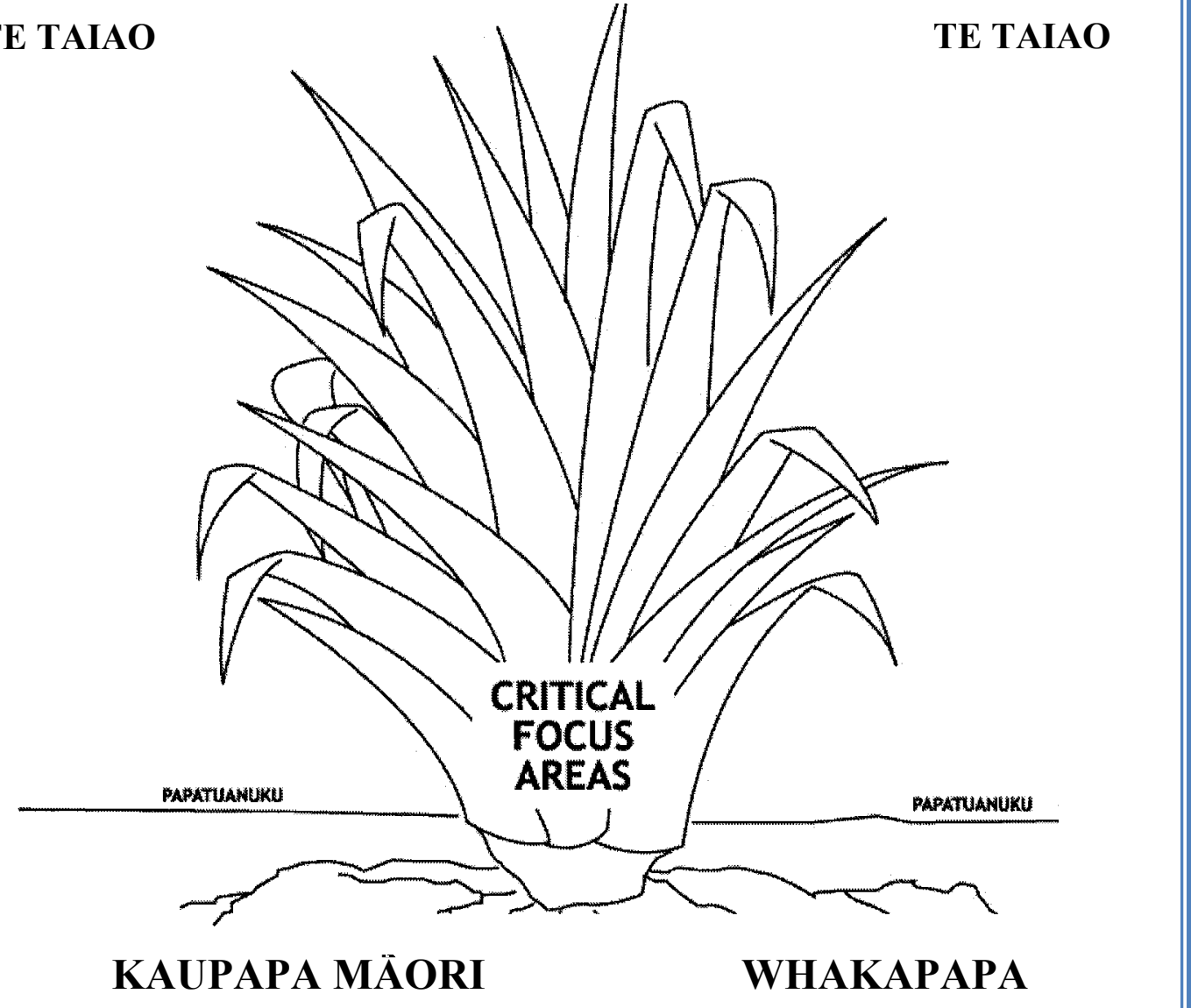

MĀORI WOMEN

TE TAIAO

TE TAIAO 
The framework assists to focus the analysis and is grounded in the theory, literature review and information generated through the interviews with the participants. (Hutchings 2002:77) developed criteria against which the questions for inclusion in the framework were tested. Where the responses were mostly 'yes' these were considered relevant and included. The criteria I have applied ensures greater relevance and specificity to my research:

- Relevance to Māori women;

- Made visible the concerns of Māori women;

- Challenged colonial, patriarchal ideologies and masculinist hegemonies";

- Supports challenges to the abuse and suffering endured by Māori women and children victims of family violence; and

- "Supports a decolonising agenda."

The critical focus areas include: Development, Te Tiriti O Waitangi, Decolonisation, Tikanga and Te Reo Māori. The corresponding questions related to each critical focus area:

- Development:

- How do Māori women in Refuge undertake development?

- How do they know their development goals have been achieved?

- How does development in the Refuge fit within the broader development discourse?

- Te Tiriti $O$ Waitangi:

- Are Māori women able to exercise their rights as guaranteed under Te Tiriti to achieve the development goals and aspirations of the Refuge?

- Tikanga and Te Reo Māori:

- Can Māori women express their 'Māoriness' through Tikanga and Te Reo in the development of the Refuge?

- In what ways is development enhanced?

- Decolonisation

- How does a decolonisation agenda assist in the development of the Refuge?

- What power constructs are over-come in the pursuit of de-colonising agendas?

- Which constructs remain? 
I discuss these themes in relation to the research objectives to:

- explore the meaning of Māori development in a Refuge environment;

- investigate the expression of Mana Wahine by Māori women Refuge advocates; and

- identify the extent to which Mana Wahine has influenced decolonisation.

\section{Limitations}

Part of the learning experience for researchers involves understanding and acknowledging the limitations of an approach, managing problems that are unavoidable, unforeseen and unexpected despite the best laid plans are (Tolich and Davidson, 1999). The relatively small number of research participants means this research is not exhaustive or representative of all Māori women. Despite my very best efforts at following the rules of research, my values, biases and judgements may have filtered into the interviews and influenced a participant's perspective or response. This potential dilemma was mitigated through careful use of the Interview Guide $^{46}$ to keep the interview on track and ensure any discussion about me or my experience was kept to a minimum.

\section{Conclusion}

My responsibility to design a research process for the participants so that they could comfortably respond accurately and honestly (Patton, 2002) has been met. I believe the research framework presented in this chapter is an appropriate and effective way to maintain the integrity of the information while creating spaces for Māori women to participate in a process often viewed with suspicion and contempt. Most importantly the framework enables Māori women to become visible and their experiences and stories heard.

\footnotetext{
${ }^{46}$ Attached as Appendix One.
} 


\section{CHAPTER FIVE}

\section{Presentation of Research Information}

"... struggles to challenge the racism, sexism and classism of this society have a long his/herstory and ours is but a contribution to the work our tipuna have already started" (Kathie Irwin, 1990).

\section{Introduction}

At the heart of this thesis are interviews with six Māori women and their experiences of managing a small NGO and supporting Māori women and children victims of family violence. Over a two month period, I spent approximately 20 hours talking with Māori women about the role of Mana Wahine in the development of the Refuge. This chapter presents the information gathered from those discussions.

\section{Interview Themes}

A number of themes emerged during the interviews which the participants viewed as contentious and continue to impact on the current collective and its activities. To ensure ethical considerations were observed and to mitigate any risks associated with this research, consent ${ }^{47}$ was sought from each participant to ensure they were comfortable for their comments to be attributed to them. I believe the research process is just as important as the final thesis product, therefore it was important to demonstrate 'giving power back to the participants' by ensuring they understood how their comments were used and that they were represented accurately.

It is also important to mention the passion and commitment of the participants to the Refuge kaupapa. I noticed during several interviews, intense emotions were triggered for some participants and this aspect of the research process is difficult to represent. My point here is to present each participant's staunch belief in the Refuge and its kaupapa of 'zero tolerance of family violence' and to convey to all readers of this thesis that the stories told to me were engaging, rich, heart-warming, sad, happy and very often inspiring.

\footnotetext{
${ }^{47}$ Attached as Appendix Two.
} 
The key themes discussed in this chapter are in no particular order or priority and reflect the way they emerged in the interviews. Each transcript was read, coded then organised into four main themes. For ease of discussion and to demonstrate the interrelated nature of the issues raised by the research participants, I have grouped together similar sub-themes. This is useful where there was an overlap on a point of discussion or where participants discussed similar or even different aspects of the same theme. I have chosen not to present these ideas separately, preferring instead to 'weave' them together in a story, in much the same way they were told to me. The main themes are outlined next.

Development - the participants conveyed very clear ideas regarding development in the Refuge. They focused on defining development and identifying the factors that contribute to positive development for women and children clients, and at an organisational level, the collective. Practical ways to implement the goals and longterm vision of the Refuge were discussed alongside the role of the collective as agents for social change.

Māori Development - all participants were proponents of Māori development and working towards Tino Rangatiratanga. The focus of discussion was Māori culture, Tikanga and Te Reo as instruments for the expression of Māori development and aspirations. The involvement of Kaumatua (elders) providing guidance and support to staff was also raised as an important means through which positive development from a kaupapa Māori perspective is facilitated.

Mana Wahine - all participants discussed the role of women in both traditional and contemporary contexts and while their views were similar in many respects, differences were also identified. The common elements include women's diverse and multiple roles and the tensions that sometimes arise, demonstrating whānaungatanga and the role of men in the Refuge's development work.

Justice and Equality - this theme includes discussion on parallel development which is predicated on the Te Tiriti and its significance to the work of the Refuge. Colonisation was also discussed. The participants were passionate advocates for the 
expression of Mana Wahine and discussed their experiences of dealing with injustices and overcoming various forms of oppression while undertaking the work of Refuge.

The way forward - the participants' hope for women and children was to live in communities free from violence. They discussed where they saw the Refuge in five years time, the role it will play in the community, the range of support services it will provide and the make up of the collective. This section concludes with one piece of advice from each participant for future collectives which is based on her experiences as a Refuge advocate.

\section{Development - contributing factors and overcoming barriers}

The participants discussed the vision and main goals of the Refuge and gave various examples of their understanding of development. This section presents that discussion and highlights the contributing factors that enable development in the Refuge.

Parekotuku Moore of Ngai TeRangi and Te Wharetoa (2007: pers.comm.) defined development and commented on the decision-making processes being guided primarily by the interests of women and children. She said:

It's about telling the world about the reality and experience of battered women. First and foremost it's about supporting battered Māori women to gain, maintain, and return their autonomy and their integrity as women in the role that she plays as a mother, wife, partner, whānau member.

...we would bring the korero (discussion) back always to the women and children... we would consider how this [presenting issue] was likely to impact on the women and children so that we always brought our focus and attention back to them and their interests.

Lee (2007: pers.comm) added her perspective thus:

From the time families come into Te Whare Rokiroki till the time they leave we can see changes... we can see how they have developed... and that's why we do it... that's why we are here... because you know at the end of the day... women leave us knowing that they are entitled to live a life free from violence...that this is a basic human right that they actually have... that is what development means to us and it's real.

Mamari Stephens of Te Rarawa (2007: pers.comm.) agreed and discussed the vision and main goal of the Refuge: 
Our vision is to work towards... to achieve a world for our wahine and Tamariki that is free from violence. There is increasingly, a sense that we should all be part of the solution and I feel as an agency we do need to be part of the solution... We are a Māori service for Māori and it's important we have that ability to call on other Māori services.

Carol Wrathall of Te Atiawa (2007: pers.comm.) considered development at an individual level and said:

The main goal of Te Whare Rokiroki and the reason it exists is to be a safe house for wahine and being able to keep them within a Māori environment and promote their future development so that they don't stay in violent situations.

Ana (2007: pers.comm) built on these views and discussed why the goals of the Refuge are important. She drew on ideas and experiences of whānaungatanga (family ties and kinship) to make the following point:

We believe we are the best people to support other Māori women and children because... firstly we are Māori too so therefore we have a natural affinity for our own knowing that some... not all of our lived experiences will have some similarities. I think the fact that we are Māori is very important because some of us have similar stories of surviving family violence and from these we are able to support and nurture other Māori women. Also, we might whakapapa to women and children who come into our care and our service is about caring for whānau (family).

A common issue identified by the participants was women-power, strengthening the numbers of women on the collective and having more paid positions. Dealing with complex whānau relationships and addressing broader social issues was identified as a priority by all the participants. The youngest woman to participate in this study was Awhina Fleming of Ngati Porou (2007: pers.comm) who said:

There just weren't enough women on the Collective. I recall a number of discussions about the possibility of joining up with Wellington Women's Refuge... there just wasn't the personnel resources and also personnel with time on their hands to help out with all the work... and I recall a lot of work needed to be done... I think women with a diverse range of skills are essential for Whare Rokiroki. Some women are good at being front of house and others at being at back... it's just like Tikanga on the Marae... some people are good workers behind the scenes while others are better up front and that's all good.

Mamari (ibid) had a similar view and said the challenge for the Refuge was:

Lack of person power. First and foremost we need more volunteers, more people who can give us time. That is critical to our operation in every sense of the word. If we are going to implement our vision, if we are going to achieve either effective emergency service or we truly work towards a world that is 
free from violence for our women and Tamariki...that's our biggest obstacle I think.

Parekotuku (ibid) considered matters beyond resources and staff and discussed the challenges for the Refuge in terms of its role as a lead organisation in the community.

She said:

The challenge is really about having enough time and enough resources to be effective advocates for other parts of her life. I came to realise that Refuge is just one of many services that has a role in supporting her on her journey towards ultimate autonomy. Then the challenge for us is to think and work broader than just 'her in the relationship'... we really need to be as an organisation... key players in leading the community and environmental responses that are effective so that she doesn't have to continue living with violence.

Ana (ibid) shared a similar view and discussed the significance of funding in relation to paid staff and volunteers. She cited an example that highlighted the importance of the role of Refuge workers and volunteers:

Not enough funding to employ more people to work longer with women and children means that our priority [is reduced to] focus on crisis work. This is important, but our focus should be broader and include other areas such as raising the profile of the Refuge and its services, community networking, working with other members of the whānau. We try to spread ourselves in as many areas as possible but sometimes it is just not realistic.

Further examples of the efforts of the Collective to facilitate development of the Refuge were provided by Parekotuku. She discussed her role as a volunteer and highlighted some of the barriers she encountered:

We got better at knowing what type of energy and skills we wanted to be a part of the Collective. We got better at identifying and choosing volunteers. Also, maintaining community visibility and responding to whatever was going on in the community at that time. I would be rolled out to front the Refuge service and talk about what we did to the most conservative elements of our community at a time when racism was very rife. You know with a name like Te Whare Rokiroki... people didn't know us or what we were about... so we started as a collective to use our full name and therefore increase our visibility. Ten years ago use of Te Reo was quite limited and to say long Māori words was seen by many as too hard... and this was actually a barrier to us accessing the predominantly white, middle class putea. So there was a barrier of fronting up as tangata whenua and ensuring the voices of battered Māori women were heard. There were two layers of obstacles we needed to work through to bring the voice, the aspirations of battered women to any audience. 


\section{Māori Development - Māori culture, Tikanga and Te Reo}

Durie (2003) asserts Māori development as economic, social and cultural advancement which includes aspirations for greater autonomy, revitalisation of culture and language and a direct approach to delivering services to Māori. All participants articulated a clear commitment to the vision of the Refuge and its focus on family violence prevention and intervention. Achieving its goals and objectives is no easy feat for the collective yet none are deterred. The data confirmed the participants are staunch advocates for Māori development. In this next section, I present that data which focuses on Māori culture and the expression and influence of Tikanga and Te Reo. Some participants have been quoted at length and their stories are largely unedited to ensure their stories are reflected accurately.

Mamari (ibid) discussed her view of Māori development and explained the relationship between being a Māori woman and the kaupapa of the Refuge. She drew on her personal experiences of joining the collective thus:

I think that the main way for Māori to achieve effective Māori development would be for Māori to have freedom and go for it. In some ways Whare Rokiroki is lucky because it already has a certain level of freedom to achieve things for Māori... it's like a mandate that those of us who are in mainstream who are attempting to carve out a pathway for themselves, don't have.

I joined Whare Rokiroki because I was looking for somewhere to learn about being Māori. When I arrived in from Christchurch in 1990 I knew I was Māori but I didn't quite know what that meant having come from a 'white' city... I know I had a Māori name and little else... As soon as I knew there was the opportunity to go to a kaupapa Māori organisation and provide services from a kaupapa Māori perspective I jumped at that chance. I can't recall how I phrased that to myself but I do know that there was the desire to meet Māori women and to get to know other Māori and Te Whare Rokiroki is an awesome organisation for that... [it] is accepting of women who come to us for precisely that reason but not only that reason. So it's a safe place to be as Māori as you are and for learning to be more Māori than you are. In my case it's not so much that culture made a difference, I came to the organisation to be changed by the culture... so there is a presumption that culture was going to make a difference to me as an individual.

...someone once described learning a culture as being in a 'spiritual straitjacket'. You can't quite get out of the situation you are in. Whare Rokiroki opened up a path for me to explore what it meant for me to be Māori. And also be able to meet Māori women who came from a range of different backgrounds... tuturu (real or true) Māori... and others like myself who looked Pākehā, had a Māori name and don't quite know what they're doing, 
but they're there anyway. And the organisation has always been respectful... whatever the other flaws Whare Rokiroki has had, that has not been one of them. We've always been respectful of women no matter what cultural connection they had... it could easily have been 'mana munchers' (arrogant) in place but it wasn't and I'm very grateful to Te Whare Rokiroki.

Parekotuku (ibid) discussed her reason for choosing to belong to an organisation dedicated [amongst other things] to development goals:

What I loved about Te Whare Rokiroki was the loyal group of friends I found and what we had in common was our absolute belief that we as Māori women had a right to all the good things in life. We had a right to be healthy and here in this world. The work was about relationships, moving forward in positive ways, nurturing, being strong and empowering Māori women - and the same goals [applied to] the collective.

Awhina (ibid) considered Tikanga and its influence to the collective's processes:

The collective meetings were very intense, very political with some pretty huge issues to be dealt with. There was also some kind of take (problem, issue) to be dealt with. I was brought up on a Marae and I found the collective meetings in particular to be quite institutionalised... this caused me some tension. The meetings were quite process driven. However, whānaungatanga and manaakitanga (to care or show concern, being hospitable) were strong and important practices, for example we would shared kai (food) ... the women were pretty good to me... they would come and pick me up to attend meetings and drop me home afterwards... I really appreciated that and I felt like I belonged... it was lovely... people were very Aroha (loving) in their ways... and that was special.

As a member of the collective with over ten years experience Ana (ibid) talked about the pro-active strategies used to celebrate Māori culture particularly in the Refuge safe house. She draws on Tikanga and Te Reo thus:

I think what brings us together is that we have a particular worldview which is based on Māori culture and that makes us unique. You know in the Whare (house) we actively look for ways to celebrate our culture so we encourage Tikanga and Te Reo and many of our tamariki (children) are fluent anyway which is choice. These things are really important and it's like that with the collective. We celebrate our Tikanga and Te Reo through Waiata (song), karakia (blessing), manaakitanga... the other thing is that there have been times when it's been appropriate for collective women to support other women from their own iwi ... Whare Rokiroki is lucky in a way because a Māori focus on issues relevant to us can be dealt with in our own way... unlike say in Mainstream organisations where the dominant culture and therefore the dominant worldview, which is not Māori I might add, prevails. When we work with our own people it is important to be in touch with them and get alongside them to find their answers rather than dictate how they should be living their lives...this is at the heart of a Māori organisation working for Māori. 
Carol (ibid) was the only participant to advocate for drawing on the wisdom of Kaumatua as a way to ensure the Refuge's kaupapa remained relevant and safe. Like Ana (ibid), Carol (ibid) gave several examples of Tikanga and Te Reo contributing to the positive and safe cultural practices within the Refuge:

I would really like to have a wider support ope (group) that we have access to - more wahine who represent a range of ages. I think it's important that we have more kuia available to support and guide us in our work. It would also be good to have kuia (female elder) and kaumatua (male elder) from other iwi (tribe) available to support us with their wisdom which is based on lived experience. If we were to have two to three kuia available to support us I think would be tremendous. They could korero (talk) with us as a collective, meet with us and help guide and shape our practice... this would be the first thing on my wish list.

Tikanga for me is about celebrating all things Māori, to do things very Māori and promote that because a lot of wahine may be urban Māori and may not have access to the Reo, to their own iwi and Hapu. They may be quite removed from their own Marae. Tikanga for me is about being able to confidently participate in Māori processes. Simple things like karakia, Waiata, being able to sit down at a table share kai and be one whānau. Being able to care for one another. Having our kuia and kaumatua there to advise us on how we should be behaving forward in everything that we do... because a lot of us a fairly young... well not old and definitely not kuia status but we do need that guidance from time to time to ensure what we are doing is correct and we are not doing any harm... and we are working with the whānau at Whare Rokiroki consistently... having it tika (correct) basically. I believe if we have access to kuia, Kaumatua and processes that are tika and pono then our kaupapa Māori development as a collective is assured. This in turn makes us better at giving support to other Māori women and children.

Ana (ibid) commented on the expression of Māori culture in the safe house and how

Te Reo Māori is normalised and actively encouraged:

I think [Māori culture] enables the collective to act from a position of strength... we can celebrate who we are. In a world that is often hostile to our ways and to us, we can celebrate who we are by doing things like karakia our kai, use Te Reo and observe the rules of tapu (restrictions) and noa (unrestricted) in the whare which are useful practices. Things like not wearing shoes in the whare...

The children's area too which is dedicated to them and was actually developed by several children in the whare at that time...is a beautiful space. There are Māori words with pictures on the walls, bright colours - it's warm and inviting. Children who come into that space just love it and they know that they are special... this is how we show Aroha. 
Parekotuku (ibid) discussed the way cultural values positively influence the work of the Refuge and some of the differences between the role of Tangata Whenua (indigenous people) and Tauiwi (non-Māori) women who work in the Refuge movement.

How we are different to our Tauiwi sisters I think is around our cultural values such as manaakitanga (showing hospitality), tiakina, the whole thing about being able to awhi (help or support) the person no matter where they are from. Manaakitanga means we know how to open our doors and provide a really good service, how to embrace [women and children clients] and how to look after them for whatever length of time it takes. We know what it means to be connected to more than just the individual which is very key to the needs of a battered woman and her family. We can do the work of Refuge because we are Māori and because we are tangata whenua and when we get it right for us, we get it right for everybody. What's right for Māori is right for everybody. It's based around the principles of manaakitanga, Whakawhānaungatanga... yeah.

The discussions present a range of views that are holistic and confirm development in the Refuge environment is premised on Māori knowledge and world-views. Māori culture, Tikanga and Te Reo are clearly the instruments for the expression of development (Second Māori Taskforce on Whānau Violence, 2002).

\section{Mana Wahine and the roles of Māori women and men}

Hutchings (2005:48) asserts:

"Mana Wahine is derived from Kaupapa Māori (Māori ideology). It is the definition and application of kaupapa to situations and analysis by Māori women and challenges current colonial patriarchal ideologies and hegemonies".

The participants discussed their diverse and multiple roles as leaders, carers, champions, mothers, partners and women connected to whānau. They spoke at length about the realities of being a Māori woman committed to pro-Māori philosophies and explained the challenges they faced in undertaking the work of the Refuge particularly their support role with women and children.

Carol (ibid) discussed women's strength as enabling the support role in the work of the Refuge:

We are all very strong women in our own rights and we are very whānau oriented... we care about each other... you stand strong in your understanding of an issue and it's safe to do that. You know there are disagreements around 
the table and that's OK... like in any organisation, any whānau... however, you are safe to be strong to have your own opinions... to contribute to any korero (discussion). For us, when we walk forward we support each other even when we don't always agree...

Lee (ibid) agreed and commented thus:

[Mana Wahine is] not something that is visual or sign-posted on the front door but it is the underlying culture of Māori women who play a part in the collective. It's why we do [Refuge work]. The women are strong, independent, professional, understanding and empathetic, who care for other Māori women. I also think our culture plays a huge part in the way we do our work. I think we are comfortable with our Māoriness which may not be obvious to others but I know other Māori women can easily identify this strength.

Mamari (ibid) also agreed and defined Mana Wahine as:

Being able to exercise authority in your own right and in relation to whānau. Having the ability to stand and to be strong as a woman. Having authority. [Mana Wahine] doesn't need to be stated expressly... we are women acting in a way that we hope will be for the betterment of women and children but ultimately for all whānau. It's not that we exclude anyone... we are about empowering women and children who then are able to feed that back to the whole whānau...

Parekotuku (ibid) discussed her understanding of Mana Wahine and what it meant for her at an individual level and in relation to her support role. She was the only participant to present an analysis of Mana Wahine in terms of her sexuality and expression of sensuality. She said:

Well to me, Mana Wahine means - a strong woman... as in she looks strong, she feels strong, her senses are strong. I've had the pleasure of being part of discussions on Mana Wahine and ultimately the concluding korero has come back to where women have identified other Māori women as having mana they are strong, confident women, they have vision, a track record and history of major achievement for all Māori women such as Te Puea, women from the Māori Women's Welfare League such as Mira Szaszy.

For me as an individual Mana Wahine is about being totally comfortable in my own skin, and being comfortable with my sexuality and being sensual and expressing myself in a sensual way. This is something that I think we as Māori women don't do enough of. I also think we are very disconnected from our vagina. Being totally comfortable in our own skin is about knowing and understanding who we are and being able to stand with pride and confidence...

When we are working with battered women and children, their mana has been trampled down and squashed and diminished... my part is to get alongside her and support her to rebuild and reconnect. My role is to reassure her that despite her loss and while she breathes she still has the capability to be a 
strong woman. See, a lot of those women are able to identify who is a strong woman...but not necessarily acknowledge themselves as knowledgeable, strong women.

The data confirms the participants placed full responsibility for violence against women and children on partners most of whom were male, and demanded accountability for those actions. However, Mamari (ibid), Awhina (ibid) and Parekotuku (ibid) also considered broader contextual issues and discussed the role of men. Mamari (ibid) said:

I don't think we see ourselves like some other organisations do, that we are exclusive or anti-male. But we do see Mana Wahine as being integral to whānau.

Awhina (ibid) viewed the roles of men and women as being complimentary and interchangeable. She argued for balance rather than power-over another person:

I don't like some feminist views that argue 'everything should be about women'...changing paternalism to maternalism, because that itself is an imbalance and I don't think that that is right either. I think Mana Wahine recognises that men and women have different roles and these are interchangeable but neither has the power over the other. Whenever I think of Mana Wahine I think about the story of IO (Supreme Being) and 'I' represents the male side of IO and O the women's side. These are representations of the male and female, all in one. For me this means that women are not below or above men, we are equal and different at the same time.

Parekotuku (ibid) on the other hand said:

Another area of work which was significant in our development was that we were constantly looking for Māori men to work alongside us. Many women on our collective had relationships and male partners who supported them. They were very supportive in the back-ground caring for their wahine which was great. Some would come out and collect during the annual appeal while others would cook for us. However, we were looking for Māori men, for brothers who had a political analysis, who could talk about family violence, understand males as perpetrators of violence... and be prepared to work with us to end violence.

Having Māori men work alongside the Refuge continues to be an area for further development as Parekotuku (ibid) noted:

In my view [Māori men working in the area of family violence] was and still is an area we didn't quite clinch. We are still lacking in strong Māori men leaders in Wellington that we can work with. 


\section{Justice and Equality}

The theme - Justice and Equality reflects the participants' views in terms of seeking to uphold the rights of Māori women and children. It also captures the participants' ideas of expressing Mana Wahine and ultimately Tino Rangatiratanga. It is important to convey an increase in intensity of the participants' feelings as they recounted their experiences to me. At least once during each interview, participants expressed indignation, anger, frustration and sadness in their struggle to preserve Tino Rangatiratanga for themselves and Māori women and children.

The sub-themes in this section comprise Te Tiriti as the foundation document for parallel development, knowledge of resources and access to them and colonisation. All participants discussed examples of implementing parallel development particularly with Wellington Women's Refuge (WWR) whom they referred to as their "Tauiwi sisters" (Mamari ibid, Carol ibid, Lee ibid). Despite a number of frustrations and setbacks, the relationship with WWR was viewed as important by all participants, one which they agreed to preserve and nurture. Their comments are presented next.

Ana (ibid) reflected on the implementation of Te Tiriti through the parallel development policy and the impact this has had on the Refuge's relationship with WWR:

Well I think Whare Rokiroki has honoured our part in the relationship with our Pākehā sisters - whereas they haven't. We have written the Treaty into our practice and it's an important part of our policy... which was negotiated between the two Refuges some time ago. I think Whare Rokiroki has a very good understanding of this policy but they [Tauiwi sisters] do not. Particularly the part about equity of resources. Many women [from the Tauiwi Refuge] are new and they weren't around when this policy was developed and agreed.

“... sometimes I think I'm being ignored or people don't believe me when I have to talk on behalf of a woman or represent the Refuge. The Police, WINZ staff, sometimes doctors, even our Pākehā sisters at the other Refuge treat me like I'm an idiot... cheek of it...

Maybe if they did some training around colonisation then they might understand the policy. They just don't treat us as tangata whenua and that has soured relationships...

Mamari (ibid) agreed with Ana that some people do not have a full appreciation or understanding of Te Tiriti. She said: 
The last few years have greatly increased my understanding of the Treaty as a document. How it does and doesn't operate in society. I think in some ways we don't have a lot of understanding of the Treaty. For ordinary people, it becomes a bit of a mantra without necessarily knowing what that actually means. The idea of the Treaty is very powerful because it's behind a lot of what we do or say with our sister Refuge and how we talk to other organisations... From a technical perspective, I think what we do in Whare Rokiroki is an embodiment of Article 3 around citizenship as well as being an embodiment of taonga under Article 2. So what we do and how we act are attributable to the principles according to the Treaty as we understand them. Sometimes I'm worried about our understanding and what that means. I know that people may not necessarily understand the document in context. Yeah so I think the effect [of the Treaty to Whare Rokiroki] is very big, but what people's understanding of what that effect is, is not always stated.

Mamari (ibid) also discussed the effect parallel development has on relationships with other organisations:

Our relationship with other organisations tends to flow from an understanding of covenant or suppose to flow from an understanding of covenant with Māori and Pākehā - hence parallel development relationships etc. But on a day-today level that gets lost and people forget where that relationship comes from. Our relationship with our sister refuge is not that great because there has been a moving away from the Treaty and a departure from why we're in this 'relationship' in the first place. It's all very well having an understanding of the Treaty and how it works and affects us on a day-to-day basis but when other people namely our Treaty partners have a different view or don't understand the Treaty themselves... it can get lost... that relationship can get lost...

Carol (ibid) commented on the relationship with WWR and identified the importance of adequate resources that could be accessed easily. Funding for services was viewed as an important issue by all participants and highlighted the reality for NGOs like the Refuge which are heavily reliant on Government and local communities for funding to implement critical services. Carol (ibid) said:

There are two ways [the Treaty] affects the work of Whare Rokiroki? First ensuring that Te Whare Rokiroki has a voice and participates in all of the discussions on whānau violence around Wellington, the wider community and across New Zealand. It's important that we are there at the decision making table inputting our concerns, our ideas for whānau and to help move them forward so that we are living a life free from violence.

I think the other issue too is related to funding and do we have proper access to funding and information about funding. This also applies to resources, within the Refuge... Another issue is the relationship we have with our Tauiwi sisters. Yes we are a Māori women's Refuge but we care very much about our Tauiwi sisters. When they are in trouble and need us to assist them we are there, that's our role as Treaty Partners and one we take very seriously. 
Parekotuku (ibid) talked about her experiences building relationships with WWR and made connections to accessing limited resources. She was the only participant to draw insight from the realities of her tipuna (ancestors) thus:

The Treaty is a document that grants me status as tangata whenua and I remember being with the collective of Te Whare Rokiroki and working alongside our Pākehā, Tauiwi colleagues and everybody else who is nonMāori... sometimes it was really difficult and really tried my patience and I am a very patient person... I remember issues around the distribution of resources and it wasn't until we developed a stronger, closer working relationship with our Pākehā colleagues that it opened doors to resources and there were doors that opened up to us that we didn't even know about.

I remember my own frustration and disappointment when I discovered they [Tauiwi Refuge] would often get huge donations or a steady flow of dollars and resources that we never got access to... one - because people didn't know about us, second - it was difficult to pronounce our name and therefore identify who we were and our sister Refuge was not quick to identify us nor could they really, particularly in the way we wanted. We were a proactive lot back then and saw an opportunity to forge ahead our discussions with them around sharing more of 'the pie' with us. These things are never easy... establishing and nurturing relationships I mean... what must it have been like for our tupuna?

And finally the participants discuss colonisation. Carol (ibid) considered decolonisation processes as necessary to the work of the Refuge and mana-wahine. She said:

Part of the decolonisation process for Te Whare Rokiroki is to reconstitute our own Whaakaro and put that into everything we do. That cultural reconstruction process is always on-going, it never stops. The more we do this we are in fact decolonising ourselves. We are not trying to oppress the oppressor; neither are we continuing to think in an oppressed way. We are able to pick up our own mana and our own Tino Rangatiratanga. We are becoming more wahine toa purely by the fact that we are developing ourselves.

Mamari (ibid) focussed on indigenous knowledge and traditional ways of living, and the impacts of colonisation on cultures the world over. She defined colonisation, considered the historical context alongside a contemporary reality. She commented:

I think awareness of the colonisation process and what it does to people indigenous peoples around the world and what it has done particularly to Māori people in New Zealand is extremely important. We need to know where we have gone. Colonisation has resulted in the wholesale change and partial destruction of traditional ways of life across the planet. The legacy of colonisation has been for indigenous peoples to suffer... I'm thinking about slavery, broken families, broken cultural ties such as language and traditional 
ways of doing things. What you end up with are hybrid models... you've got indigenous peoples who are doing the very best that they can to survive in environments of change beyond their ancestor's understanding and for the most part, doing that really well... considering. And Māori are a good example of that I think. We've done some amazing things as colonised people. So can we be de-colonised? In a sense you can't take the Pākehā out of us. So for better or for worse, I am Scottish, Irish, German Māori. But what you can do is recover a sense of cultural wholeness that embraces that colonised past.

Similarly, Lee (ibid) said it was time to let go of the past and move on:

I think we should move on... we can't send the Pākehā home... I think we've come beyond that now... I might be on my own Waka ${ }^{48}$ here but I believe it's about being able to maintain what we've got rather than going back 165 years... people are still very angry and grieving. I feel people can become paralysed with their anger and grief. I think we need to move beyond decolonisation now and focus on bringing the Treaty into current New Zealand legislation...

Parekotuku (ibid) discussed the impacts of colonisation and applied the learnings to working in the Refuge.

We are an indigenous nation and we have experienced the oppression of colonisation from a dominant culture and we have lived with that for over 150 years. We can learn from that... We can do the work of Refuge because we are Māori serving other Māori and because we are tangata whenua. I think when we get it right for us; we get it right for everybody. It's based on the principles of manaakitanga and Whakawhānaungatanga.

\section{The Way Forward}

Throughout the interviews it was evident the participants were loyal to each other, the Refuge and committed to Māori women and children. While most of the participants hoped there would be no need for Refuges in the future, they admitted it was likely there would still be a demand for Refuge services. All participants were hopeful that future generations would insist on a society free from violence and mobilise themselves to facilitate change. They viewed their work as an investment in the future of whānau, hapu, iwi Māori.

Parekotuku commented thus:

I would love to see Whare Rokiroki with a bigger collective of paid workers... Higher visibility in the community is another goal I would like to see. I

\footnotetext{
${ }^{48}$ In this context 'Waka' refers to being a single voice or without agreement from others.
} 
consider the community has moved on in terms of the way it sees family violence as being something that is hushed into the background and kept invisible. We are one of many services that are as good if not better... we are unique in that we work alongside Māori women.

Her advice for future collectives was:

Keep going... don't loose sight... grow your numbers... have a real clear strategic plan, be clear about your goals and priorities... if you are clear about your goals then the task is about sticking to your plan...keep doing what you're doing. Keep having faith that what you are doing is $\mathrm{OK}$ - it is good.

Similarly, Mamari's hope for the future was directed at the Refuge taking on a key leadership role:

Whare Rokiroki will be in more of a position of leadership in the Wellington community as far as Māori initiatives and violence in the home is concerned... we need to be...

Her advice for future collectives was simple:

You've got to look after your people. You've got to find a way to bring people on board; you've got to find a way to nurture them. To have a house, to have an office - those things are bricks and mortar. So my primary piece of advice is... even with all the strategic planning, all the business planning, all the lobbying, this means nothing if we can't look after our people.

Carol (ibid) ended her interview with the following encouraging words:

I would say stick to the Tikanga, because the Tikanga doesn't change and it's a really strong base to keep us moving forward and continue to develop the wairua (spirit), the hinengaro (mind/consciousness) the facets that make up us... that make up our staff... and continue to develop our people. If we have strong, well developed staff and volunteers then we are essentially rolling out development ideas and principles to our whānau... and I think if we stick to that track then we will undoubtedly contribute to the greater good for all.

Ana's (ibid) hope for the future was thus:

I think [the collective] has proved [it]self as a credible organisation that does great work for Māori in the Wellington area and we should be supported better by Government. This would enable us to do more work with women and particularly the children... we could draw on expertise such as facilitators, educators etc. I hope we can do something big for our people. Getting more people on board is also a priority. If we had more people we could have more people monitoring, networking, building relationships...visiting with women in the community. At the moment that is just not possible. Working this way is a more pro-active approach to helping whānau.

Her advice to future collectives was:

Let women know that you are on their side and let them know they are valued because they are our future. Support them and believe in them because for a 
Māori woman to come and ask for help - it takes a lot. We owe it to her and to ourselves to give her all the support she needs. 


\section{CHAPTER SIX}

\section{Critical Discussion}

To be Māori is normal

(Pipi et al, 2004:141)

\section{Introduction}

This chapter brings together the information gathered from the interviews and the key ideas from the literature review presented in Chapter Three to answer the research questions:

- explore the meaning of Māori development in a Refuge environment;

- investigate the expression of Mana Wahine by Māori women Refuge advocates; and

- identify the extent to which Mana Wahine has influenced decolonisation.

\section{Development}

Thomas (2000:48) considers 'development' as:

A vision or measure of a desirable society, an historical process of social change, and a deliberate effort at improvement by development agencies."

The participants' shared vision for the Refuge was articulated by Mamari (2007: pers. comm.) as: "a world for our wahine and tamariki that is free from violence." Implicit in Mamari's (ibid) view is a commitment to stopping violence and to alleviating the effects of abuse endured by women and children. Woods (2005:52) says this type of development is:

"... a process of change which increases the opportunities or capabilities that people have while at the same time, reducing the absolute suffering they experience."

The Refuge's philosophical position promotes the aspirations and goals of Māori women and is enshrined in its Constitution (1990). Its advocates strive for a society that is free from family violence, where Māori women occupy legitimate places in New Zealand society and lead meaningful lives, and where they exercise rights as guaranteed under Te Tiriti $\mathrm{O}$ Waitangi. These aspirations provide a strong basis for the Refuge's activities and motivate the drive, energy and passion of the advocates. I 
contend that this is exactly what Thomas (2000:48) refers to "as a vision or measure of a desirable society."

The participants' multiple roles with the Refuge are varied and require skills and flexibility. They saw 'political' activism as critical to facilitating positive change (Parekotuku, 2007: pers. comm.; Mamari, ibid, Lee, 2007: pers. comm.).

Those participants with over ten years experience with the Refuge, possessed an indepth understanding of the responsibilities and pressures associated with facilitating social change. Despite the challenges and potential risks, none were deterred. All participants demonstrated loyalty to the Refuge and articulated an unwavering commitment to Māori women and children. I could not help but admire their courage and determination. They also demonstrated a sharp awareness that stopping violence against women and children, at an individual level requires attitudinal change which would take much time and perseverance. This is what Irwin (1990:85) refers to as:

“... struggles to challenge the racism, sexism and classism of this society have a long his/herstory and ours is but a contribution to the work our tipuna have already started."

I wondered why these women would give so much to an organisation and to women and children, most of whom they barely knew. I discovered that a Refuge advocate cannot be motivated or driven by material rewards or incentives, simply because there are none. The participants believe Māori women and children deserve to be treated with respect and dignity in their relationships, families and wider communities. Perhaps being able to support women on their journey of rediscovery and self-help was reward enough.

\section{A Human Rights Issue}

To be an advocate for the Refuge is to be a champion for the rights of Māori women and children. The participants' sense of outrage at the injustices and unfair treatment endured by Māori women and children spurs their courage and determination to take an active stand against violence and abuse. The Refuge's work has strong connections to the work of other NGOs around the world, by taking up action to secure equality for women and the protection of basic human rights and freedoms. The salient point 
which emerged from the interviews is that violence is a form of discrimination and a human rights violation, (Parekotuku ibid, Maamari ibid, Ana ibid, Lee ibid).

The work undertaken by the Refuge is about ensuring women exercise their human rights and basic freedoms and therefore it could be said that the Refuge is directly contributing to the goals of CEDAW. The latest report to CEDAW from the New Zealand government lacked any mention of the Refuges' efforts which is disappointing given the call from the United Nations (2006) to build and sustain strong multi-sectoral strategies which should be coordinated nationally and locally.

In its report the United Nations said:

"[Governments] should build on the work done by NGOs, scale up and institutionalise it and share experiences with other countries... Governments should take responsibility for the systematic collection and publication of data, including supporting NGOs... engaged in such activities" (ibid: vi).

The suggestion here, is that the New Zealand government and policy makers can learn much from the work undertaken by Refuge. This would be particularly true insofar as dealing with the issues that emerge as a result of the intersection of gender-equity and race. This research confirms Māori women in Refuge must continue to deal with racist, masculinist hegemonies which are oppressive. (Parekotuku ibid, Ann ibid, Carol ibid, Mamari ibid). Making visible the particular experiences of Māori women survivors of violence means the participants have a strong understanding of human rights violation. More importantly, they are actively engaged in meaningful remedial strategies which at an international level may have relevance and offer insight to other indigenous peoples.

The Refuge's view of development is similar to Korten's (1995, cited in Todaro 2000) 'people centred' view of development and it is obvious that the principles advocated by Korten (ibid: 77) are upheld by the Refuge:

- Justice: which involves ensuring a "decent human existence for all people"

- Sustainability: careful use of limited resources for future generations; and

- Inclusiveness: where people belong, contribute and participate in a family, community and wider society. 
The Refuge has engaged in this political agenda for over twenty years whilst the NCIWR $^{49}$ to which the Refuge is a member, has driven and led the same political agenda at a national level for over 35 years. This is surely what Thomas (2000:48) means when he refers to "an historical process of social change."

This research confirms the efforts of the Refuge are a deliberate and considered attempt at development (Thomas, 2000). However, belonging to an organisation that is proudly supportive of women, encourages the positive expression and celebration of Māori culture, and actively promotes lesbian visibility situates the Refuge in the margins of society (Cram; 2006, Smith; 2006, Irwin; 1994, Smith; 1999). The weight of marginalisation is compounded by the fact the Refuge is run by Māori for Māori and operates in a largely 'main-stream' environment. Smith (2006) reminds us that:

“... as an indigenous minority group Māori experience forms of marginalisation in relation to the dominant society and ... that as a society on the margins there are groups of Māori who are marginalised from Māori society and culture, some of whom may also be excluded from the dominant society and many of whom may also experience multiple forms of marginalisation."

Her fundamental message is not one of pessimism and she advocates that researchers can respond effectively to marginalisation through “... research 'with', 'for' and 'as' Māori... (ibid:5).” The participants' say the same about their work supporting women and children. For example Parekotuku (ibid) said:

"... the challenge for us is to think and work broader than just 'her in the relationship'... we really need key players in leading the community and environmental responses that are effective so that she doesn't have to continue living with violence. We are the best ones to support her because we understand violence, we are Māori and we have no hidden agendas... we do this mahi (work) as Māori women for Māori women... it's simple really...

My own example is a case in point. As a Māori woman I actively choose to engage in research with Māori women, for the benefit of Māori women. This position reflects my social interest and standpoint (Collins; 1997, Hartsock; 1983) which as Smith (2006:6) aptly says:

"There are researchers... who actively choose the margins, who choose to study people marginalised by society, who themselves have come from the

\footnotetext{
${ }^{49}$ The National Collective of Independent Women's Refuges is a national entity. Te Whare Rokiroki has been an affiliated member since its inception in 1985 .
} 
margins or who see their intellectual purpose as being scholars who will work for, with and alongside communities who occupy the margins of society."

The research shows the participants' resolve to challenge all hegemonic ideologies that are colonial and masculinist. I detail some of the challenges identified by the participants later in this chapter to demonstrate a strong alignment to the Mana Wahine framework. By creating space for women and children's voices and stories to be heard, the development aspirations of the Refuge are upheld in ways that promote integrity and respect. This is reflected by Parekotuku (ibid) who said:

"We always brought our focus and attention back to [the women and children] and their interests."

\section{The Role of Men}

Parekotuku (ibid) discussed the importance of men being actively involved in strategies to eliminate violence against women:

"In my view [Māori men working in the area of family violence] was and still is an area we didn't quite clinch. We are still lacking in strong Māori men leaders in Wellington that we can work with."

Violence has disastrous effects on the development of women (Duvvury and Nayak, 2003) and unless men are engaged as part of the solution "...we will be attempting to resolve this multi-dimensional problem from a very limited perspective" (INSTRAW, 2004). The research clearly supports Parekotuku's view, (Bridges; 2008, Schrock and Padavic; 2007, Robertson et al; 2007, Britton; 2006, United Nations; 2006, INSTRAW; 2004, Johnson; 2003). The involvement of men in the work of the Refuge is an area which requires further development. For the Refuge to be as effective as it can be and adequately address gender-equality, this matter will need to be the focus of urgent attention.

In response to the objectives of this thesis I contend that the meaning of development within the Refuge is multi-faceted. On one level, development in Refuge may be interpreted as the pursuit of social justice for Māori women and children. This research shows how the Collective targets its effort to challenge individual and community attitudes and behaviours that perpetuate violence and render Māori women and children silent and invisible. The Collective demonstrates a strong commitment to make the plight of victims of family violence visible and ensure their 
voices are heard and more importantly understood by policy and law makers and the wider community. On another level development in Refuge is about forging a legitimate place in New Zealand society for Māori women and children to enable them to be active, connected and participating in their respective communities. If Māori women and children are to realise their human potential (Korten 1995 cited in Todaro 2000) their basic rights must be achieved and that means family violence must stop.

\section{Māori Development}

'Development' within the Refuge is premised on the assumption that being Māori is normal, Māori culture is the natural means to achieve development goals; and only Māori must find their own answers to mobilise Māori communities to action, (Parekotuku ibid, Ana ibid, Carol ibid, Maamari ibid, Lee ibid). I discuss some of the issues that arose for the participants as they worked to achieve the Refuge's development goals.

Smith (1999) asserts self-determination is a fundamental goal of Māori development. Durie (1998:457) agrees and says Māori development is:

“... practical and intimately bound to the aspirations and hopes within which contemporary Māori live. Essentially Māori self-determination is about the advancement of Māori people, as Māori, and the protection of the environment for future generations."

Flax roots organisations such as the Refuge are sites where Māori women are actively engaged in the pursuit of a violence free society, one that is safe for Māori women and children, where they belong and can actively participate. Parekotuku (ibid) noted development in Refuge as being about:

"Supporting Māori women to gain, maintain and return their autonomy and their integrity as women in the role that she plays as a mother, wife, partner and whānau member."

Ana (2007, pers. comm.) refers to the influence of a Māori worldview to the development goals of the Refuge. Throughout her discussion she asserted Māori development comprises; advancement for women and the organisation, aspirations for greater autonomy, and services provided by Māori for Māori (Durie, 2003). Ana (ibid) argues her cultural identity provides a strong basis from which she is able to 
support other Māori women which is one of the fundamental aims of Māori development, (Cram; 2005, Durie; 1998, Walker; 1995, Awatere-Huata; 1995, Reid; 1994, Henare; 1994, Irwin; 1992)

"We believe we are the best people to support other Māori women and children because... firstly we are Māori too so therefore we have a natural affinity for our own knowing that some... not all of our lived experiences will have some similarities. I think the fact that we are Māori is very important because some of us have similar stories of surviving family violence and from these we are able to support and nurture other Māori women."

\section{Tino Rangatiratanga}

Durie (2003) argues Māori development involves economic, social and cultural advancement together with aspirations for greater autonomy. This research confirms Māori development in the Refuge environment is ultimately about Tino Rangatiratanga which the participants confirm is the reason they chose to remain involved in the work. To facilitate Tino Rangatiratanga, I argue that Māori development must address the marginalisation of Māori women by ensuring they can be seen and their voices and stories are heard. For far too long the voices of Māori women go unnoticed, are not considered legitimate or valuable. This is evident in Ana's (ibid) story:

“... sometimes I think I'm being ignored or people don't believe me when I have to talk on behalf of a woman or represent the Refuge. The Police, WINZ staff, sometimes doctors, even our Pākehā sisters at the other Refuge treat me like I'm an idiot... cheek of it...I've only been doing this work for over 15 years much of it unpaid...

To achieve Māori development Maamari (ibid) said:

"I think that the main way for Māori to achieve effective Māori development would be for Māori to have freedom and go for it."

The "freedom" Maamari spoke of may well be a development goal in itself. She refers to Tino Rangatiratanga and the intellectual, physical and spiritual space required to facilitate broader development aspirations and opportunities for Māori. The literature confirms Tino Rangatiratanga is a fundamental goal of Māori development, (Cram; 2005, Durie; 1998, Awatere-Huata; 1995, Walker; 1995). 


\section{Advancement}

The imperatives of the Refuge closely reflect a desire to bring about social and cultural advancements for Māori women (Refuge Constitution, 1990). That said, working with clients from low socio-economic backgrounds and dealing with the constraints of funding and resources impacts on the ability of the Refuge to achieve these imperatives.

Irwin (1990) identified ten key challenges for Māori women feminists and their work, of which: "To live instead of surviving" (ibid: 84) is her story of survival and isolation. It is also a story of the important of self-care.

At an organisational level, what it means to 'survive' is evident in the comments from Ana (ibid) and Parekotuku (ibid) who discuss the realities of being dependent on the goodwill of the Government and wider community for funding and donations to pay for the costs associated with running the Refuge. According to Lee (2007 pers. comm.) accessing sufficient resources is a necessary yet time-consuming duty which detracts from the more important task of supporting Māori women. It was evident that the Refuge advocates operate in a type of 'survival mode' where much of their efforts are focussed on securing sufficient resources for clients and the operations of the Refuge.

To move beyond 'survival' mode requires better support from Government and communities by way of resources to attract paid staff and provide support for volunteers. Irwin's story of self care (1990) is an important one for the participants to note. Throughout the interviews, no-one identified this as an issue, yet intuition and past experience tells me that volunteer self-care is critical to personal well-being, moreover to the well-being and longevity of the Refuge. I contend additional resources are required to enable the Refuge to provide a comprehensive and effective suite of support services while strengthening existing services. There appears to be little chance of additional resources and Governments and communities should be on the alert. This country cannot afford for the work of Refuges to stop or diminish in any way. 


\section{Māori Culture - Tikanga and Te Reo}

Over half the participants readily admitted they were not fluent speakers of Te Reo, had lived outside their Rohe for a long time and some even commented they did not look Māori - sometimes being mistaken for Pākehā. Nonetheless, the participants viewed Māori culture, Tikanga and Te Reo Māori as the primary means through which development in the Refuge is expressed. This research confirms the strong influence Māori culture, Tikanga and Te Reo Māori has on every aspect of the Refuge's activities and more widely towards its overall development goals. Embodied are Māori values which prescribe acceptable and unacceptable behaviours for the Refuge's relationships with clients and other organisations and the way its services are delivered. Recognition and acceptance of the value of Māori cultural practice in the Refuge's philosophies, protocols and activities is what makes the work of the Refuge distinctive and unique. I agree with the Second Māori Taskforce on Whānau Violence (2002:10) which asserted the transformative qualities of Tikanga include:

"reflect[ing] that relationships are intact, processes are in place to preserve and protect whakapapa and there is a level of understanding about the importance of whakapapa relationships and processes... its transformative qualities is as a guide for behaviour that is based on Māori philosophies about the way in which whānau should behave towards one another."

Ana (ibid) asserted Tikanga, Te Reo and the Māori culture is what brought the Refuge advocates together and gave rise to whānaungatanga. She said:

"We actively look for ways to celebrate our culture so we encourage Tikanga and Te Reo..."

The participants also discussed what it means to observe 'cultural safety' in the work of Refuge and ensure the practices of Refuge advocates' stay safe. The following comments from Mamari (ibid) and Lee (ibid) demonstrate this:

"Whare Rokiroki is a safe place to be as Māori as you are and for learning to be more Māori than you are... we've always been respectful of women no matter what cultural connection they had."

"I think it's important that we have more kuia available to support and guide us in our work. It would also be good to have kuia and Kaumatua from other iwi (tribe) available to support us with their wisdom which is based on lived experience" 
The meaning of safety was raised as an issue by all but one participant. In the Refuge context, 'safety' also refers to fears associated with being misunderstood, not accepted and considered as strange. In a predominantly 'white' country such as New Zealand, being Māori places one on the margins of society and being a woman places one on the edge of those margins. Johnston and Pihama (1994) calls this 'difference' which they say leads to exclusion. The Refuge project is as much about family violence prevention and intervention as it is about reclaiming power and a legitimate place for Māori women in New Zealand. One would think as Tangata Whenua with whakapapa, Māori women and children enjoy a legitimate place in this society. On many levels, is seems the opposite is true.

It has been over 150 years since first contact with Pākehā and the rights of Māori women as guaranteed under the Treaty continue to be ignored, trivialised and trampled. Māori women continue to be marginalised in New Zealand, (Cram; 2005, Te Awekotuku; 2004, Johnston and Pihama; 1994, Sykes; 1994, Evans; 1994). Not surprising then is the view of the participants that the Refuge is a place of safety and a haven just as much for them as their women and children clients (Parekotuku ibid, Lee ibid, Mamari ibid, Carol ibid).

In answer to the objectives of this research, the meaning of development in the Refuge environment is a place where Tikanga, Te Reo and Māori culture provides the platform through which the lives of Māori women and children are simultaneously improved and enriched. It is the uniqueness of a shared Māori culture that draws women to Refuge and creates solidarity and in a sense, builds new whānau relationships. In my observation the Refuge is also a place where the bonds of friendship, loyalty and commitment to end family violence for Māori women and children are established, nurtured and ultimately flourish. This is encapsulated by Ana who said:

"[Māori culture] enables the collective to act from a position of strength... In a world that is often hostile to our ways and to us, we can celebrate who we are..."

Next I bring together the literature and research to discuss the second objective of this thesis - how Mana Wahine is expressed by Māori women Refuge advocates. 
Pihama (2001:262) used Mana Wahine as an umbrella term under which she positioned Māori women's theories. She asserts:

"Mana Wahine is a framework that enables us to engage in the rediscovery and pro-active work that is necessary for Māori and refers to Māori women's analyses that encompass the complex realities of Māori women's lives."

The vision of the Refuge and its advocates is "Communities living free from family violence" (Refuge Constitution, 1990). To achieve these aspirations the advocates must engage in a continuous struggle to challenge behaviours and attitudes on a number of different levels. Irwin (1990:80) reminds us that sometimes struggle is necessary but this is not a new concept for many Māori:

“... struggles to challenge the racism, sexism and classism of this society have a long his/herstory and ours is but a contribution to the work our tipuna have already started."

To undertake Refuge work and take up this challenge requires compassion, strength of character, determination and a positive belief that Māori, particularly Māori women deserve amongst other things, a 'good life', one that is free from violence. The meaning of Mana Wahine in Refuge is complex and multi-faceted. Te Awekotuku (1991: 262, cited in Pihama 2001) makes an important point about Mana Wahine and asserts:

"Mana Wahine is not reactionary; it is not a response or reaction to male violence... but is a process whereby Māori women are able to be pro-active in our determining our future."

I agree and would add to this argument that when the mana, wairua and tinana of Māori women are trampled by members of her whānau and they are battered or worse - killed, Mana Wahine is the process whereby Māori women can take back control of their lives and pro-actively determine a better future. This brings me to the issue of power which I discuss next.

\section{Power}

Māori women challenge the assumptions, philosophies and practices of individuals and institutions within New Zealand society that are oppressive and dominate Māori women relegating them to positions of invisibility and silence, (Hutchings; 2005, Pihama; 2001, Smith; 1999, Johnston and Pihama; 1994, Irwin; 1992). These works explain what it means to take back power, challenge assumptions that are inherently 
racist and sexist and ultimately exercise Tino Rangatiratanga. I believe Māori women have just as much right as non-Māori to live, participate and enjoy the benefits of living in New Zealand society and I argue that through the works of the Refuge, which is articulated by the research participants, Tino Rangatiratanga is exercised and Mana Wahine realised.

All participants discussed their efforts as Refuge advocates as a way of contributing to women clients exercising authority over their lives, enabling them to stand in their own right and be strong women. Taking back power and creating space for Māori women's voices accords with both the Refuge's philosophies and the Mana Wahine ideology. The achievement of same is the heart of the work of the Refuge and the very reason for its existence.

Parekotuku (ibid) discussed these issues as follows:

"When we are working with battered women and children, their mana has been trampled down and squashed and diminished... my part is to get alongside her and support her to rebuild and reconnect. My role is to reassure her that despite her loss and while she breathes she still has the capability to be a strong woman. See a lot of these women are able to identify who is a strong woman... but not necessarily acknowledge themselves as knowledgeable, strong women.

Through her story, Parekotuku (ibid) highlights two very important matters. First, to facilitate effective change within the community and support women to shift towards positions of strength requires an understanding of the effects of family violence and what it means to be powerless then move to a position of strength and take back power. It is Māori women who invariably are best placed to understand the struggles of other Māori women because they are already in the process of their own decolonisation and have a depth of awareness regarding living with the effects of a colonised reality.

Parekotuku's (ibid) second point is the importance of whakapapa which is an intrinsic part of the strategies to reclaim power.

"Whakapapa establishes connections and relationships and brings responsibility, reciprocity and obligation to those relationships." (Second Māori Taskforce on Whānau Violence, 2002:8) 
The Refuge operates on a pan-tribal basis which means it is run by women who affiliate to different Iwi. Women from all Iwi are welcome and considered equal. The same is true for women and children clients where their Māoriness is embraced and they are regarded as equal with other women in the Whare including all members of the Collective. In terms of working alongside women, a 'taken-for-granted' position is held by the Refuge advocates where by virtue of clients being Māori they are assumed to be whānau and are treated as such - with compassion and concern. Thus, the Refuge demonstrates a form of whakapapa in all its complexities. Hutchings (2002:47) reminds us that whakapapa is about:

“...identity and knowledge transmission and brings with it a way of viewing and understanding relationships."

I suspect that this level of positive affirmation is rarely found in New Zealand. Other people and agencies particularly those with Māori clients or colleagues might learn something through the Refuge's example about how to work with Māori, particularly women, in ways that are meaningful and uphold their mana. In conclusion and to highlight a key message that emerged from the research, one which was articulated by at least three other participants, is this comment from Ana:

"Māori women are the best people to support other Māori women and children ..."

\section{Justice and Equality}

All participants maintain a firm commitment to advance the social, cultural and economic aspirations of Māori women and children. Part of that resolve involves speaking out against actions, behaviours and assumptions that are unjust, unfair and fail to treat Māori women as equal to others - male and female alike. The participants' views on the pursuit of justice and equality for Māori women is part of the wider decolonisation project which is as much about exercising their rights as guaranteed under Te Tiriti as it is about expecting to be treated fairly and with respect. It should be noted that the Refuge is one of the few organisations in New Zealand that seeks to 'live' Te Tiriti which according to NCIWR ${ }^{50}$ :

\footnotetext{
${ }^{50}$ http://www.standbyme.org.nz/organisation-profiles/womensrefuges?PHPSESSID=be116d24eb82860f6d5ec29aad70cc6. Accessed 11 November 2007.
} 
"Reflects its fundamental commitment to the partnership created through Te Tiriti $\mathrm{O}$ Waitangi through in all policies and programme it initiates or supports."

In their discussions regarding overcoming racism, poverty and other oppressions, all participants named a single situation as the subject of growing concern. Their stories involved the tenuous relationship with the Collective of Wellington Women's Refuge (WWR), a Refuge made up of Tauiwi women. The challenges and tensions within this relationship were obvious and all participants levelled criticisms at WWR for demonstrating a limited understanding and an apparent unwillingness to observe the Parallel Development policy which is premised on Te Tiriti. The participants also expressed their anger, shock and resentment at information being withheld regarding the availability of resources and resistance to sharing existing resources with the Refuge. These concerns bear the hallmarks of frustrations expressed in 1984 when pioneering Māori women were struggling for Tino Rangatiratanga and a legitimate place within the Refuge movement with sufficient means to implement Māoridetermined change and improvement. The following criticism was noted by NCIWR thus:

"For Tauiwi, a huge shift was required for them to give over power, learn to operate under bicultural models, and continually challenge their own racism and lack of understanding of Tikanga Māori. ${ }^{51,}$

I contend the real issue here is power. The women at WWR appear not prepared to share the dominant position they hold in the community and they exercise that power by excluding Māori women from the decision-making processes in relation to supporting other Māori women who seek Refuge services; and they withhold vital information about resources. In the absence of a research project that presents the views of WWR it can only be surmised that they have a limited awareness of the impacts their actions have on the Refuge. During the interviews none of the participants ventured a solution or indicated what the next steps for a relationship with WWR might be. Within this situation, there have been numerous occasions where the Refuge has attempted to negotiate and 'take back power' to forge new realities for themselves and Māori women and children clients - with little success. The question no-one asked was "What will it take for WWR to act with integrity and observe the

\footnotetext{
${ }^{51}$ Women's Refuge Herstory. Accessed on 5 January 2008 from http://www.womensrefuge.org.nz.
} 
tenets of the Parallel Development policy?" The track-record for Pākehā women is hardly encouraging. It has been 168 years since the signing of Te Tiriti O Waitangi and 24 years since Parallel Development was adopted by the Refuge movement. Undoubtedly some progress has been made. However the question remains as to whether progress occurred as a result of strong, co-operative alliances with WWR or has it occurred off the backs of Māori women who refuse to accept anything less than Tino Rangatiratanga.

Despite the obvious challenges, the participants view the relationship with WWR as important, even critical to stopping violence against Māori women and children. Not one participant argued for the relationship with WWR to be dissolved, in fact, the opposite was true. I expect the work ahead for the Refuge, insofar as building bridges and developing a relationship with WWR will continue to present challenges. Reclaiming mana and exercising Tino Rangatiratanga to continue working with a Refuge whose attitudes and actions appear hostile, even aggressive, speaks volumes about the participants' commitment and integrity.

It appears WWR cannot see the extent of their racism and greed because they fail to see how they use their positions of privilege to wield power and dominate the women of the Refuge. Despite the potential for these tensions to drive a 'bitter wedge' in the Refuges' relationship it is heartening to observe the humility of the women at the Refuge like Carol (ibid) who said:

"Yes we are a Māori women's Refuge but we care very much about our Tauiwi sisters. When they are in trouble and need us to assist them we are there, that's our role as Treaty Partners and one we take very seriously."

To sum, the expression of Mana Wahine by Mãori women Refuge advocates is located in contestations of power and authority. Notwithstanding the demands for its support services the Refuge must also deal with oppressions such as racism, sexism and poverty. Considering the effect limited resources and staff place on the capabilities of the Refuge to respond at all to considerable pressures, it is nothing short of amazing that the women of Refuge meet the needs of clients and maintain an ideological position of resistance with passion and commitment. Perhaps this is a pre-requisite for the role of Refuge advocate which in some respects would explain the tenure of 
the Refuge working in the area of family violence prevention and intervention for over twenty years.

Next, I weave together discussion on these issues as part of the decolonising strategies used by the participants and I answer the third research objective - the extent to which Mana Wahine has influenced decolonisation.

\section{Decolonisation}

The most common form of oppression which Māori women have or are likely to experience within New Zealand is colonisation. The literature confirms colonisation has had disastrous and catastrophic effects on Māori women, much of which can still be felt today Mikaere (1994).

According to the Second Māori Taskforce on Whānau Violence (2002:19) colonisation was:

"A full-scale attack on Māori cultural processes and forms. Although our Tupuna fought the relocation of power and authority, over time there has been a surrendering (by force) to the coloniser. This has taken many forms from collusion, collaboration, indifference, greed and vanity. To surrender is to admit defeat. It is a fatalistic response. Survival has been expensive. The price is the loss of cultural knowledge, identity and practices, the breakdown and dysfunction of whānau, hapu and iwi, the confiscation and theft of Māori land and the pauperisation of Māori. The contemporary outcomes are epidemic whānau violence and systemic dysfunction."

The impacts of colonisation are identified by Johnston and Pihama (1994:3) and they highlight the layers of oppressive constructs endured by Māori women thus:

"the intersection of race and gender has for Māori women culminated in dominant oppressive ideologies providing complex assertions of inferiority."

The research confirms all participants were well aware of the effects of colonisation for Māori women and children. Throughout the interviews it was clear that their lived realities had facilitated an in-depth understanding of those effects and the types of strategies it would take to facilitate decolonising agendas. This depth of understanding can be seen in the comments made by Mamari (ibid):

"Colonisation has resulted in the wholesale change and partial destruction of traditional ways of life across the planet... [and] indigenous people suffer." 
Parekotuku (ibid) agrees and had this to say:

"We are an indigenous nation and we have experience the oppression of colonisation from a dominant culture and we have lived with that for over 150 years."

The point here is to acknowledge that decolonising strategies undertaken by the Refuge are predicated on the participants' experiences as Māori women. These experiences are informed by Māori ways of knowing and views of the world, Māori culture, Tikanga and Te Reo. Carol (ibid) discussed her view of decolonisation thus:

"Part of the decolonisation process for Te Whare Rokiroki is to reconstitute our own Whakaaro and put that into everything we do. That cultural reconstruction process is always on-going; it never stops."

Carol (ibid) alludes to the process of "unlearning and disengagement from colonial notions of who we are as Māori women" (Hutchings 2000:46). The reconstruction she refers to rejects western ideologies that assume a position of superiority and dominance over Māori women's knowledge, realities and sense of self. In effect, Carol (ibid) offers hope to Māori women by encouraging them to reclaim herstorical constructs and space to tell their own stories (Smith 1994).

Maamari (ibid) on the other hand considers the future for indigenous peoples who live with a colonised reality and had this to say:

“... you've got indigenous peoples who are doing the very best that they can to survive in environments of change beyond their ancestor's understanding and for the most part, doing that really well... considering. And Māori are a good example of that I think. We've done some amazing things as colonised people. So can we be de-colonised? In a sense you can't take the Pākeha out of us. So for better or for worse, I am Scottish, Irish, German Māori. But what you can do is recover a sense of cultural wholeness that embraces that colonised past."

In response to the third objective I turn to Hutchings (2002). A Mana Wahine analysis is indeed a decolonisation analysis.

\section{Summary}

The meaning of development in the Refuge environment is as diverse as the realities of the Māori women participants in this research. Development is a human rights issue and its goal is Tino Rangatiratanga. Development involves political activism and 
taking up the mantle of social change to challenge patriarchal masculinist ideologies which are oppressive. The women in Refuge recognise women's stories, realities and experiences are the bases from which long-term positive change is possible.

The expression of Mana Wahine by Mãori women Refuge advocates involves the pursuit of justice and equality for Māori women and is grounded in contestations of power and control. The role of a Refuge advocate is to challenge actions, behaviours and assumptions that are unjust, unfair and fail to treat Māori women respectfully, as equal to others - male and female alike. That role involves negotiating and creating ways to actively celebrate and promote Māori culture Tikanga and Te Reo. In this way the whakapapa, wairua, Mauri and mana of Māori women is honoured and uplifted.

The extent to which Mana Wahine has influenced decolonisation involves decolonising strategies undertaken by the Refuge are predicated on the participants' diverse and unique experiences as Māori women which are informed by Māori ways of knowing and viewing the world, Māori culture, and aspirations of Tino Rangatiratanga. Decolonisation is also an implicit part of the Refuge's philosophical position and an essential part of a Mana Wahine ideology. With courage and determination the women of Te Whare Rokiroki forge a legitimate, safe place in New Zealand society for Māori women and children. The work of Refuge offers hope for the future. This is Mana Wahine. 


\title{
CHAPTER SEVEN
}

\author{
Conclusion \\ "The shifting of a definition of theory from the descriptive mode \\ to one that is related explicably to practice and therefore is informed by \\ the politics and social realities within which the practice is located, \\ makes theory worthwhile for Māori." (Leonie Pihama, 2001:86)
}

To conclude, I speak back to the aims of the research by revisiting the main points from the critical discussion. Final reflections are made regarding:

- the effectiveness of the research framework, what worked and areas for further development;

- my positionality in relation to this project;

- the Refuge's contributions to international development approaches and ways in which these approaches might strengthen the Refuge's work; and

- $\quad$ areas for future research.

\section{Responding to the Research Questions}

Development within the Refuge environment involves resistance and struggle against oppression to ensure the fundamental human rights of Māori women are upheld, they occupy a legitimate place in New Zealand society and lead meaningful lives. Championing the rights of women and child as an advocate in Refuge requires courage and determination because facilitating social change is fraught with complexities. Development in Refuge also involves creating space for the voices of Māori women to be heard and their stories told. Tino Rangatiratanga is the ultimate goal and motivates the Refuge to continue to strive for the realisation of development goals and aspirations for Māori women and children.

The expression of Mana Wahine by Māori women Refuge advocates occurs daily as Refuge advocates support Māori women and children and challenge behaviours and attitudes. That expression is premised firmly on the belief that Māori values, ways of knowing and understanding the world are legitimate and is manifest in the Refuge through Māori culture, Tikanga and Te Reo. 
The extent to which Mana Wahine has influenced decolonisation is obvious in many aspects of the Refuge. The research clearly demonstrates that decolonisation is an essential part of the Refuge's philosophical position and strategies to stop violence and abuse. A Mana Wahine analysis provides a solid foundation to appreciate the complexities associated with the work of the Refuge and understand some of the motivations of its advocates.

\section{Efficacy of the framework}

If I were presented with the opportunity to undertake a similar research project with Māori women workers in Refuge, I would adopt the same research framework. Given the nature of this project it was important to develop a framework which would meet the rigours of the academy, was appropriately responsive to Māori values and culture and inform a final product that would be useful to the Refuge. This indigenous framework embraces traditional Māori beliefs and customs and legitimises Māori knowledge and ways of knowing. Its strength is in the articulation of Māori women's experiences and theorising about their past, current and future realities.

Exploring colonised realities transforming power relationships and constructs accords with the research framework (Seuffert cited in Milroy 1996). These goals were part of the reasons why I embarked on this project and time will tell whether improvement or transformation has in fact occurred for the Refuge. I conclude that a Kaupapa Māori epistemology, Mana Wahine and Qualitative methodologies and interviews were a sound basis from which to undertake the research.

Research is about power (Te Awekotuku, 1991) and while overall 'control' of this project was not located within the Refuge or the participants, their stories have the power to transform attitudes and behaviours and change lives. Around the world, NGOs like the Refuge and indigenous people like Māori women are leading campaigns of change. 


\section{Positionality}

I held duel positionalities within this project; as a former member of the Refuge 'whānau' and student researcher. My responsibilities together with the ethical considerations regarding conflicts of interest were carefully managed through regular Supervision and reflexivity throughout the research process. The research journal I maintained was an effective means to monitor progress and track any changes. The participants were also invited to confirm the transcribed interviews and the presentation of the research information (Milroy 1996). Each participant was presented with a bound copy of their interview and for the Refuge a final copy of this thesis. Giving back to the participants demonstrates reciprocity and while it was never made explicit, this small token goes some way to satisfying my obligations to the participants. Overall, these approaches were consistent with the framework and strengthened the research process.

\section{Linkages to International Campaigns}

Within an international development context, contributions from Māori women as experts in the field of development appear limited. An example close to home, is the Development Studies programme ${ }^{52}$ where the absence of Māori-centric research and the works of Māori academics are noticeably absent. There are many Māori women whose work could be the source of much insight and learning for students undertaking the Development Studies programme. Māori women academics such as Fiona Cram, Jessica Hutchings, Kathie Irwin, Aroha Mead, Ani Mikaere, Leonie Pihama, Linda Tuhiwai Smith and Ngahuia Te Awekotuku are actively engaged in projects with a development and indigenous focus. Their stories would add academic insight and a vibrant richness to development discourses.

Another example is Development Theory and Practice ${ }^{53}$ which has no articles, reports or musings from Māori women even in areas one might expect to see their works such as Gender and Development, Alternatives to Development and Development Issues. The Development Studies programme runs for a full academic year and in 2007 the contribution from Māori was a single hour. The preference appears to be to look to Third-World countries or the 'big' countries such as England, Europe or the United

\footnotetext{
${ }^{52}$ A course offered at Victoria University as part of the Masters Degree in Development Studies.

${ }^{53}$ Course notes that are a compilation of articles, reports and books.
} 
States for academic insight and reference. What does this say about the production of knowledge and whose knowledge matters? Perhaps the absence of Māori views reflects a belief that those views are unimportant or irrelevant to the Development Studies course. Perhaps the absence of meaningful Māori representation in the curriculum also explains why, out of 25 students I was the only Māori.

None-the-less, the work of the Refuge is important and there are gains being made in many ways but spaces must be created for their stories to be told. Their work contributes to local, national and global agendas to end violence, facilitate development and bring about long-term, positive change for Māori women and children. This research contributes to broader discourses including the Development Studies programme by way of a nuanced perspective regarding the pursuit of development goals and aspirations by and for Māori.

\section{Future Research}

This thesis joins with other mana wahine voices and the issues which emerge provide tools and intellectual capital for others working in the area of eliminating violence and abuse. Given the prevalence of violence against women and children in New Zealand, there is an urgent need for further work in this area. Research needs to be undertaken on the leadership role of Māori women in Refuge to understand the effectiveness of violence intervention and prevention. Effective strategies are developed from Tino Rangatiratanga positions and can provide guidance at operational and research levels for other Māori women, NGOs, governments and policy makers. More work needs to occur to explore the following issues:

- How can the collaborative efforts of the community be enhanced?

- How does decolonisation contribute to the elimination of violence?

- What other gender-equity models exist in New Zealand?

I recommend Mana Wahine and Kaupapa Māori epistemologies and methodologies are applied to other contexts and environments which will enable the deconstruction of western knowledge and knowledge production to provide understandings of power and equality from an indigenous perspective. I encourage other Māori researchers particularly to adopt a similar research framework because there are too few Māori 
researchers and Māori-centric research. It is important to develop legitimate spaces for the voices of Māori, particularly Māori women and ensure their stories are heard. In addition, I believe it is critical that research for Māori embraces our culture, knowledge and ways of understanding the world rather than objectifying us as primitive or quaint.

Furthermore, research is required on the relationship between Mana Wahine frameworks and international development. For indigenous cultures around the world, a Mana Wahine perspective can provide insight regarding colonised realities and inform strategies to create new realities predicated on cultural uniqueness and autonomy.

And finally, I return to the participants, without whom this research would not have been possible. Their words of encouragement point the way forward for the Refuge.

Parekotuku (ibid):

Keep going... be clear about your goals then the task is about sticking to your plan...keep doing what you're doing. Keep having faith that what you are doing is OK - it is good.

Mamari (ibid):

You've got to look after your people. You've got to find a way to bring people on board; you've got to find a way to nurture them.

Carol (ibid):

I would say stick to the Tikanga, because the Tikanga doesn't change and it's a really strong base to keep us moving forward and continue to develop the wairua (spirit), the hinengaro (mind/consciousness) the facets that make up us.

Ana (ibid):

Let Māori women know that you are on their side and let them know they are valued because they are our future. Support them and believe in them because for a Māori woman to come and ask for help - it takes a lot. We owe it to her and to ourselves to give her all the support she needs.

Mana wahine is a movement towards new ways of defining ourselves. The role of Māori women in Refuge is to pursue decolonising agendas and positive development for Māori women and children. Challenging hegemonic, colonial masculinist ideologies, Māori women lead the way to the culture of Tino Rangatiratanga we seek. 


\section{BIBLIOGRAPHY}

Anderson, T. A. (1994). He Karanga. In A. Brown (Ed.), Mana Wahine: women who show the way (pp. 208). Auckland: Reed Books

Awatere, H. (2000). Me Aro Koe Ki Te Ha o Hine-ahu-one: Pay Heed to the Dignity of Women (pp. 16).

Awatere-Huata, D. (1995). Māori sovereignty: The Māori perspective. Auckland: Hodder Moa Beckett Publishers Limited.

Baez, B. (2002). Confidentiality in qualitative research: reflections on secrets, power and agency. Qualitative Research, 2(35).

Bishop, R. (1999). Kaupapa Māori Research: An indigenous approach to creating knowledge. In N. Robertson (Ed.), Māori and psychology: research and practice - The proceedings of a symposium sponsored by the Māori and Psychology Research Unit. Hamilton: Māori \& Psychology Research Unit.

Battiste, D. M. (2005). Indigenous Knowledge - Foundations for First Nations. World Indigenous Nations Higher Education Consortium - Indigenous Knowledge: Journal 2005, 60.

Bridges, T. S. (2008). Dying to be Men: Youth, Masculinity and Social Exclusion. Journal of Men's Studies, 16(1), 117-119.

Briton, H. (2006). Organising against Gender Violence in South Africa. Journal of Southern African Studies, 32(1), 145-163.

Bryson, V. (1999). Feminist theories today. Feminist Debates.

Clandinin, D. J. (Ed.). (2007). Handbook of Narrative Inquiry: Mapping a Methodology. Thousand Oaks, California: Sage Publications Inc.

Clandinin, D. J., \& Rosiek, J. (2007). Mapping a Landscape of Narrative Inquiry: Borderland Spaces and Tensions. In D. J. Clandinin (Ed.), Handbook of Narrative Inquiry - Mapping a Methodology. Thousand Oaks, California: Sage Publications.

Clearinghouse, N. Z. F. V. (2006). An Agenda for Family Violence Research (2006) (Vol. 1): FVC.

Collins, P. H. (1997). Comment on Hekman's "Truth and Method: Feminist Standpoint Theory Revisited": Where's the Power? Signs: Journal of Women in Culture and Society, 22(21), 375-381.

Connor, D. H. (1997). Reclamation of Cultural Identity for Māori Women: A Response to 'Prisonisation' Women's Studies Journal, 13(2). 
Convention on the Elimination of All Forms of Discrimination against Women (2003). Summary record of the 624th meeting (pp. 10): United Nations.

Cony, S. (1993). Māori women shun domestic service. Standing in the Sunshine, 225.

Cram, F. (1997). Developing Partnerships in research: Pākehā researchers and Māori research. Sites Journal, 35, 44-63.

Cram, F., Phillips, H., Tipene-Matua, B., Parsons, M., \& Taupo, K. (2004). A parallel process? Beginning a constructive conversation about Māori methodology. Journal of Bioethical Inquiry, 1(1), 14-20.

Cram, F. (2005). Back grounding Māori Views on Genetic Engineering. In J. Barker (Ed.), Sovereignty Matters: Locations of Contestation and Possibility in Indigenous Struggles for Self Determination. Nebraska: University of Nebraska.

Cram, F. (2006). Talking Ourselves Up. In C. Aspin (Ed.), Alternative: an International Journal of Indigenous Scholarship (pp. 28-45). Auckland: Auckland University.

Cresswell, J. (1994). Research Design: Qualitative and Quantitative Approaches. Thousand Oaks, California: Sage Publications.

Dev-Zone. The Millennium Development Goals One Pager. Retrieved 14 December, 2007, from www.dev-zone.orgs/mdgs/

Division for the Advancement of Women (2005). Good practices in combating and eliminating violence against women. Retrieved 18 February, 2008, from http://www.un.org/womenwatch/daw

Duvvury, N., \& Nayak, M. B. (2003). The Role of Men in Addressing Domestic Violence: Insights from India. Development: Globalisation, Reproductive Health and Rights, 46(2), 45-50.

Durie, M. (1998). Mana Māori, Determination and Development. In Te Mana, Te Kawanatanga, The Politics of Māori Self Determination (pp. 1-20). Melbourne: Oxford University Press.

Durie, M. (2003). Nga Kahui Pou: Launching Māori Futures. Wellington: Huia Publishers.

Evans, R. (1994a). Māori Women as Agents of Change, Unifem Suffrage Conference. Waipuna Lodge, Auckland: Te Pua.

Evans, R. (1994b). The negation of powerlessness: Māori feminism a perspective. Hecate, 20(2), 53(13). 
Garda, R. (2001). 'I Want to Recover Those Things I Damaged': The experience of men's groups working to stop violence in Mexico. Development: Violence Against Women and the Culture of Masculinity, 44(3), 104-106.

Glover, T. D. (2004). Narrative Inquiry and the Study of Grassroots Associations. Voluntas: International Journal of Voluntary and Nonprofit Organizations, 15(1), 47-69.

Grimshaw, P. (1987). Women's Suffrage in New Zealand. Auckland University Press: University Printing Services.

Hall, L. (2004). Confidentially Speaking: Ethics in Interviewing. In A. Green \& M. Hutchings (Eds.), Remembering Writing Oral History. Auckland: Auckland University Press.

Harding, S. (1997). Comments on Hekman's "Truth and Method: Feminist Standpoint Theory Revisited": Whose Standpoint Needs the Regimes of Truth and Reality? Signs: Journal of Women in Culture and Society, 22(21), 72-76.

Hartsock, N. C. M. (1983). The Feminist Standpoint: Developing the Ground for a Specifically Feminist Historical Materialism. In S. Harding \& M. B. Hintikka (Eds.), Discovering Reality (pp. 283-310): D. Reidel Publishing Company.

Hayward, R. F. (2001). Needed: A culture of masculinity for the fulfilment of human rights. Development: Violence Against Women and the Culture of Masculinity, 44(3), 48-53.

Henare, D. (1994). He Whakataki. In A. Brown (Ed.), Mana Wahine: Women who show the way (pp. 8-15). Auckland: Reed Books.

Henry, E., \& Pene, H. (2001). Kaupapa Māori: Locating Indigenous Ontology, Epistemology and Methodology in the Academy. Sage, 8(2), 234-242.

hooks, b. (1989). Talking Back: thinking feminist, thinking black. Boston MA: South End Press.

hooks, b. (1995). killing rage: ending racism. New York: Henry Holt and Company.

Hoskins, C. T. K. (1997). In the Interests of Māori Women? Discourses of Reclamation. Women's Studies Journal, 13(2).

Hutchings, J. (2002). Te Whakaruruhau, te ukaipo: Mana Wahine and Genetic Modification. Unpublished Doctor of Philosophy, Victoria University, Wellington.

Hutching, M. (2004). The Distance Between Voice and Transcript. In A. Green \& M. Hutching (Eds.), Remembering Writing Oral History. Auckland: Auckland University Press. 
Hutchings, J. (2004). Claiming Our Ethical Space - A Mana Wahine Conceptual Framework for Discussing Genetic Modification. Gender and Development, 164-172.

Hutchings, J. (2005). Mana Wahine me Te Raweke Ira: Māori Feminist Thought and Genetic Modification. Women's Studies Journal, 19(1).

International Research and Training Institute for the Advancement of Women. (2004). Ending Men's Violence. Retrieved 18 February, 2008, from http://www.uninstraw.org/en/index.php?option=content $\&$ task=view\&id=909\&Itemid

Irwin, K. (1988). Māori, Feminist, Academic. SITES, 17.

Irwin, K. (1990). Challenges to Māori Feminists. In W. Harrex (Ed.), Broadsheet (pp. 79-84). Auckland: New Women's Press Limited.

Irwin, K. (1992a). Becoming an Academic: Contradictions and Dilemmas of a Māori Feminist. In Middleton \& Jones (Eds.), Women and Education in Aotearoa (Vol. 2). Wellington: Bridget Williams Books.

Irwin, K. (1992b). Towards Theories of Māori Feminists. In R. D. Plessis (Ed.), Feminist Voices: Women's Studies Texts for Aotearoa/New Zealand. Auckland: Oxford University Press.

Irwin, K. (1994a). Māori Research Methods and Processes: An Exploration. Sites Journal, 28, 25-43.

Irwin, K. (1994b). Matauranga. In A. Brown (Ed.), Mana Wahine: Women who show the way (pp. 74-81). Auckland: Reed Publishing NZ Limited.

Jackson, M. (1995). Māori, Pākehā and Politics: the Treaty of Waitangi Sovereignty as Culture, Culture as Sovereignty: Màori Politics and the Treaty of Waitangi. Paper presented at the Global Cultural Diversity Conference Proceedings, Sydney.

Jenkins, K. (1986). Reflections on the status of Māori women (pp. 12).

Jenkins, K. (2005). Mana Wahine: Māori Women and Leadership of Māori Schools in Aotearoa/New Zealand. New Zealand Journal of Educational Studies, 40(1).

Johnston, P., \& Pihama, L. (1994). The Marginalisation of Māori Women. Hecate, $20(2), 83$.

Jolly, S. (2000). 'Queering' Development: Exploring the links between same-sex sexualities, gender and development. Gender and Development, 8(1), 78-88.

Johnson, H. (2003). The cessation of assaults on wives. Journal of Comparative Family Studies: Violence Against Women in the Family., 34(1), 75-91. 
Josselson, R. (2007). The Ethical Attitude in Narrative Research: Principles and Practicalities. In D. J. Clandinin (Ed.), Handbook of Narrative Inquiry. Thousand Oaks, California: Sage Publications.

Koch, T. (1998). Story telling: is it really research? Journal of Advanced Nursing, 28(6), 1182-1190.

Leatherby, G. (2003). Feminist Research in Theory and Practice. Philadelphia PA: Open University Press.

Lee, S. (1994). He Pu Korero. In A. Brown (Ed.), Mana Wahine: Women who show the way (pp. 208). Auckland: Reed Books.

Lopez, E. P. (1991). Overcoming the Barriers: Women and Participation in Public Life [Costa Rica]. In T. Wallace \& C. March (Eds.), Changing Perceptions: Writings on Gender and Development (pp. 11-117). Oxford: Oxfam.

Maaka, R., \& Fleras, A. (2005). The Politics of Indigeneity: Challenging the State In Canada and Aotearoa New Zealand. Dunedin: University of Otago Press.

Manderson, L. (2001). Fighting Violence Against Women. Development: Violence Against Women and the Culture of Masculinity, 44(3), 6-8.

McIntosh, T. (2006). Theorising Marginality and the Process of Marginalisation. In C. Aspin (Ed.), Alternative: an International Journal of Indigenous Scholarship (pp. 46-67). Auckland: Auckland University.

Mead, A. T. P. (1996). De-colonisation and Identity: The bridge to Unite or Divide Women. In S. Olsson \& N. Stirton (Eds.), Women in Leadership: Power and Practice (pp. 49-62). Palmerston North: Massey University.

Mikaere, A. (1994). Māori Women: Caught in the contradictions of a colonised reality. Auckland.

Momsen, J. (2004). How far have we come? In Gender and Development (pp. 220243). London: Routledge.

National Collective Independent Women's Refuges. About Women's Refuge. Retrieved 2 December 2007, from http://www.womensrefuge.org.nz/index.cfm

National Collective Independent Women's Refuges. Definitions and Effects of Violence. Retrieved 18 January 2008, from http://www.womensrefuge.org.nz/index.cfm

National Collective Independent Women's Refuges. Statistics for July 2006. Retrieved 2 December 2007, from http://www.womensrefuge.org.nz/index.cfm 
National Collective Independent Women's Refuges. Women's Refuge Herstory. Retrieved 15 December 2007, from http://www.womensrefuge.org.nz/index.cfm

New Zealand Parliamentarians' Group on Population and Development. (2005). Creating a Culture of Non-violence. Retrieved 10 December, 2007, from www.fpaid.org.nz

Ormond, A. (2006). Who Determines What Story Is Told? Narratives of Marginalisation. In C. Aspin (Ed.), Alternative: an International Journal of Indigenous Scholarship (pp. 118-143). Auckland: Auckland University.

Parpart, J. (1993). Who is the Other? A Postmodern Feminist Critique of Women and Development Theory and Practice. Development and Change, 24(3), 439-464.

Patton, M. Q. (2002). Qualitative Research \& Evaluation Methods. Thousand Oaks, California: Sage Publications.

Peterson, V., Runyan, S., \& Runyan, A. S. (1999). Gender as a Lens on World Politics. In V. Peterson \& A. Runyan (Eds.), Global Gender Issues (pp. 6188). Boulder: Westview Press.

Pihama, L. E. (2001). Tihei Mauri Ora Honouring Our Voices: Mana Wahine as a Kaupapa Mãori Theoretical Framework. Unpublished Doctor of Philosophy, University of Auckland, Auckland.

Pihama, L., Cram, F., \& Walker, S. (2002). Creating methodological space: A literature review of Kaupapa Māori research. . Canadian Journal of Native Education, 26, 30-43.

Pihama, L. (2005). Asserting Indigenous Theories of Changes. In J. Barker (Ed.), Sovereignty Matters: Locations of Contestation and Possibility in Indigenous Struggles for Self-Determination. Nebraska: University of Nebraska.

Pinnegar, S., \& Daynes, J. G. (2007). Locating Narrative Inquiry Historically: Thematics in the Turn to Narrative. In D. J. Clandinin (Ed.), Handbook of Narrative Inquiry - Mapping a Methodology. Thousand Oaks, California: Sage Publications.

Ramazanoglu, C., \& Holland, J. (2002). Feminist Methodology: Challenges and Choices. London: Sage.

Ramsden, I. (1994). He Poroporoaki. In A. Brown (Ed.), Mana Wahine: Women who show the way (pp. 202-206). Auckland: Reed Publishing (NZ) Ltd.

Rathbeger, E. M. (1990). WID, WAD, GAD: Trends in Research and Practice. Journal of Developing Areas, 24(4), 489-502. 
Razavi, S., \& Miller, C. (1995). From WID to GAD: Conceptual Shifts in the Women and Development Discourse. Geneva: UN Research Institute for Social Development.

Reid, P. (1994). Hauora. In A. Brown (Ed.), Mana Wahine: Women who show the way (pp. 56-65). Auckland: Reed Books.

Robertson, N., Busch, R., D'Souza, R., Sheung, F. L., Anand, R., Balzer, R., et al. (2007). Living at the Cutting Edge: Women's Experiences of Protection Orders: The Women's Stories. 1, 292.

Robinson, G. (1998). Qualitative Methods. Human Geography, 407-432.

Royal, C. (1998). Te Whare Tapere. Unpublished Doctoral Thesis, Victoria University, Wellington.

Schrock, D. P., \& Padavic, I. (2007). Negotiating Hegemonic Masculinity in a Batterer Intervention Program. Gender \& Society, 21(5), 404.

Second Māori Taskforce on Whānau Violence. (2002). Whānau Violence - A Māori Conceptual Framework. (Ed.) (pp. 34): Government Print.

Smith, C. W. (1994). Kimihia Te Matauranga: Colonisation and Iwi Development. Unpublished Masters Thesis, University of Auckland, Auckland.

Smith, C. (2006). Being Tangata Whenua in Aotearoa in the 21st Century. Alternative an International Journal of Indigenous Scholarship, 92-117.

Smith, L. T. (1992). Māori Women: Discourses, Projects and Mana Wahine. In S. Middleton \& A. Jones (Eds.), Women and Education in Aotearoa. Wellington: Bridget Williams Books.

Smith, L. T. (1995). Toward Kaupapa Māori Research, Matawhanui Conference (Māori University Teachers Conference). Massey University, New Zealand.

Smith, L. T. (1999). Decolonizing Methodologies Research and Indigenous People. Dunedin: University of Otago Press.

Smith, L. T. (2006). Researching in the Margins: Issues for Māori Researchers - A Discussion Paper. In C. Aspin (Ed.), Alternative: an International Journal of Indigenous Scholarship (pp. 4-27). Auckland: University of Auckland.

Sykes, A. (1994). Constitutional Reform and Mana Wahine. In Te Pua (Vol. 3). Auckland: Puawaitanga.

Te Awekotuku, N. (1991a). Mana Wahine Māori: Selected Writings on Māori Women's Art, Culture and Politics. Auckland: New Women's Press. 
Te Awekotuku, N. (1991b). He Tikanga Whakaaro: Research Ethics in the Mãori Community: A Discussion Paper. Wellington: Manatu Māori: Ministry of Māori Affairs.

Te Awekotuku, N. (1992). He Whiriwhiri Wahine: Framing Women's Studies for Aotearoa. Te Pua, 1.

Te Awekotuku, N. Tamihana, S., Glamuzina, J., \& Laurie, A. (1993). Better Out Than In. In A. Else (Ed.), Women Together: A History of Women's Organisations in New Zealand. Wellington: Daphne Brasell Associates Press.

Te Awekotuku, N. (1994). He Ngangahu. In A. Brown (Ed.), Mana Wahine: Women who show the way (pp. 208). Auckland: Reed Books.

Te Kupenga Whakaoti Mahi Patunga - The National Network of Stopping Violence Services (NZ). Accessed 13 January 2008 from http://www.nnsvs.org.nz/.

Te Whare Rokiroki Māori Women's Refuge. (1985). Minutes of Te Whare Rokiroki Māori Women's Refuge Annual General Meeting. Wellington.

Te Whare Rokiroki Māori Women's Refuge. (1990). Te Whare Rokiroki Māori Women's Refuge Constitution (pp. 10).

Thomas, A. (2000). Meanings and Views of Development in T. Allen \& A. Thomas (Eds.), Poverty and Development into the 21st Century. London: Oxford University Press.

Thomas, A. (2000). Poverty and the 'End of Development'. In T. Allen \& A. Thomas (Eds.), Poverty and Development into the 21st Century (pp. 23-48). London: Oxford University Press.

Thomson, M. (2002). Boys will be boys: Addressing the Social Construction of Gender. In F. Cleaver (Ed.), Masculinities Matter! Men, Gender and Development (pp. 116-185). London: Zed Books.

Tolich, M., \& Davidson, C. (1999). Starting Fieldwork: An introduction to qualitative research in New Zealand. Auckland: Oxford University Press New Zealand.

Tong, R. P. (1998). Radical Feminism: Libertarian and Culture Perspectives. In Feminist Thought (2nd edition). St Leonards: Allen and Unwin.

United Nations. (2006). Ending Violence Against Women: From words to action. Retrieved 11 February 2008, from http://www.un.org/womenwatch/daw/vaw/

United Nations. (2007). Preventing and eliminating violence against women: An inventory of United Nations system activities on violence against women. Retrieved 19 February, 2008, from http://www.un.org/womenwatch/daw/vaw/index.htm 
United Nations. Millennium Development Goals Factsheet. Retrieved 2 January, 2007, from http://.un.org/millenniumgoals

Van der Gaag, N. (2004, November). What women have gained in the fight for equality with men - and what they are in danger of loosing. New Internationalist, 9-12.

Victoria University. (2007). Graduate Prospectus 2007. Wellington: Victoria University.

Violence Against Women Special Unit - 'It's all against the rule' state-wide campaign. Accessed 23 February 2008 from http://www.lawlink.nsw.gov.au/lawlink/vaw/ll_vaw.nsf/pages/vaw_vaw_iaatr campaign

Walker, R. (1995). Māori sovereignty: The Māori perspective. Auckland: Hodder Moa Beckett Publishers Limited.

Walsh, C. A. (1998). Participatory Research, Civil Society in the Millennium Workshop. Nadi, Fiji.

White Ribbon Campaign. Accessed on 23 February 2008 from http://www.whiteribbon.ca/about_us/\#1.

Woods, T. (2005). Alternatives to Development (Unpublished Paper): Victoria University of Wellington.

Yates-Smith, G. R. A. (1998). Hine! E Hine! Rediscovering the feminine in Māori spirituality., University of Waikato, Hamilton.

Yow, V. R. (2005). Recording Oral History. California: Altamira Press.

Zahir, F., Dalton, F., Turner, W., Gallegos, C., \& Pillay, T. (2006). Funding Proposal for Te Whare Rokiroki Māori Women's Refuge (pp. 61): Victoria University MDEVE. 
APPENDICES 


\section{Appendix One - Interview Guide}

1. Name or pseudonym.

2. When did you join and leave the Refuge?

3. Please explain your job/role with the Refuge.

4. What was special about your job/role?

5. What is the 'vision' or main goal of the Refuge?

6. Why is this 'vision' or main goal important?

7. What are the challenges for the Refuge in achieving its vision or main goal?

8. What can you tell me about the "herstorical point"?

9. Can you describe the Refuge environment prior to the "herstorical point?

10. What changes occurred?

11. What were the challenges for the organisation?

12. As a result of the "herstorical point" what changes or challenges occurred for your role?

13. What other changes or challenges did you notice?

14. What are the similarities and differences between you individual contribution and the collective's contribution to achieving the Refuge vision?

15. Overall, how did/does you contribution assist the development of the Refuge?

16. What is special about working with a collective made up of other Māori women?

17. How is Mana Wahine expressed in the working of the Refuge?

18. What does Mana Wahine mean to you?

19. In what ways does Māori culture or being Māori affect the work of Refuge?

20. In what ways does Te Tiriti O Waitangi impact on the Refuge?

21. What are the barriers to effective Māori development and how are these overcome?

22. How did/does your contribution to the Refuge impact on a 'national level' towards Māori development?

23. What relationship does your contribution to Refuge have with decolonisation?

24 . What do you think about the Refuge participating in a global society?

25 . Where do you see the Refuge in five years time?

26. Thinking about your experience with the Collective, in particular the contribution you made during the "herstorical point" what advice would you give the current Collective to support its continued development. 


\section{Appendix Two - Information Sheet}

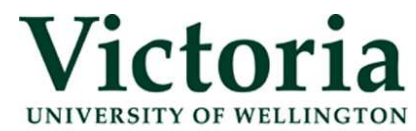 \\ Te Whare Wānanga \\ o te Ūpoko o te Ika a Māui

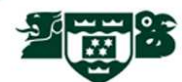

\section{Information Sheet \\ The role of Mana Wahine in the future development of Women's Refuge}

Ko Whakapunake raua ko Mangatauki nga Maunga

Ko Wairoahopupuhonengenengematangirau raua ko Tauranga Moana nga awa

Ko Te Rauhina raua ko O Romai nga Wharenui

Ko Te Rauhina raua ko Romainohorangi nga Tupuna

Ko Ngati Kahungunu raua ko Ngai Te Rangi nga Iwi

Tihei Mauri Ora.

Researcher:

Whiti Turner

Academic Supervisors:

Dr Jessica Hutchings (Ngai Tahu, Ngati Huirapa)

Ms Sara Kindon

Tena koe,

I am a Masters student in Development Studies at Victoria University of Wellington. As part of this degree I am undertaking a research project leading to a thesis. The project focuses on exploring the role of Mana Wahine in the future development of Te Whare Rokiroki Māori Women's Refuge (the Refuge). I am inviting Māori women who have experience as a past or current volunteer, advocate or paid worker with the Refuge to participate in this study.

Participants will be asked to take part in a face to face interview for approximately 1.5 hours. The interview will be recorded on tape and take place at a location and time that best suits you during June and July 2007. There may also be a follow up session of approximately one hour. Your participation is voluntary.

Participants will be identified in the research write up and their comments will be attributed to them. Participants will be given copies of the sections that they are represented in, to review and where necessary make changes prior to completion of the data analysis. If you wish, you can choose not to be identified in this research in which case you can remain anonymous or choose a nickname/pseudonym. You may also decide to withdraw from participating in the project at any time prior to the data being analysed without giving a reason. 
Upon request, the interview tapes can be returned to you and a summary of the results of the research may be made available. Please tick the relevant box/boxes on the Consent form and leave your forwarding address.

You can ask any questions before you agree to participate. It is important that you understand the purpose of the research and how your information will be treated. While conducting the research project, all information you provide will be kept secure on password protected files and restricted to me and my academic Supervisors, Dr Jessica Hutchings and Ms Sara Kindon. At the conclusion of the research project all data will be kept for six months. Following this period, the data shall be destroyed except your interview tapes should you request that these be returned.

The thesis will be submitted for marking to the School of Geography, Environment and Earth Sciences (SGEES) and deposited in the University Library. By participating in this research you are giving consent for your input and ideas to be used and made available to others through the data collected, the thesis and other publications produced which may include academic articles and conference presentations. The results of this research may be useful for Refuges, other community-based organisations and government departments as contributing to Māori women's development.

Ethical approval for this research has been granted by the Victoria University Wellington Human Ethics Committee. Their contact telephone number is (04) 463 5751 , if there are any issues you wish to discuss with them or you may wish to contact my primary Supervisor, Dr Hutchings on 021406226 or Ms Kindon on 4636194.

Heoi ano na,

\section{Whiti Turner}

Primary Supervisor: Dr Jessica Hutchings, Teaching Fellow SGEES, Ph: 021406 226, Email: J.V.Hutchings@massey.ac.nz. Ms Sara Kindon, Ph: 463 6194, Email: sara.kindon@vuw@ac.nz 


\section{Appendix Three - Consent Form}

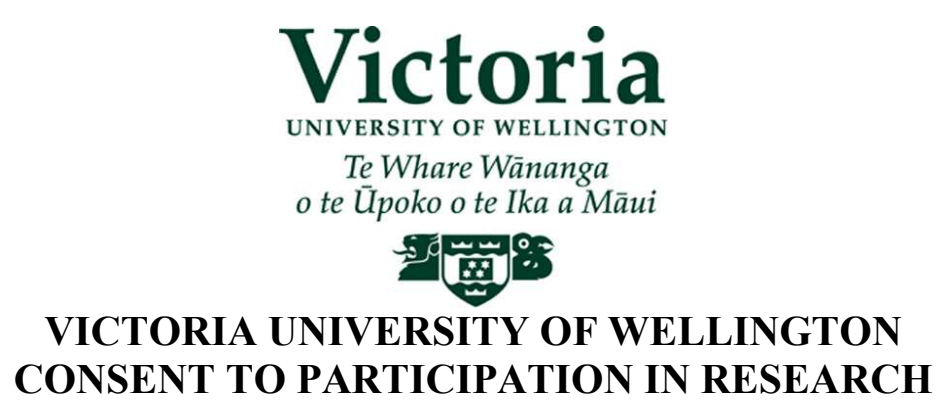

Title of Project: The role of Mana Wahine in the future development of Women's Refuge.

Please tick the boxes to show that you give your consent.

I have been given adequate information about the project and what I am expected to do to participate in this research.

I feel I am able to ask any questions and raise any issues I have with the researcher and her supervisors.

I understand that I may withdraw from participating in the research at any time before it is submitted with no consequences to me and without having to give a reason.

I agree to the interview being tape-recorded.

I would like the tape recording of my interview returned to me

I understand the interview will be transcribed.

I understand that the transcript of my interview will be available only to the researcher and her supervisors and will be destroyed at the completion of the research.

I understand that I will be asked for feedback on parts of the research where my views are represented.

After the research is completed; I understand that it will be used for a Masters thesis and possibly for further publications which may include academic articles and conference presentations. 
I understand that the transcript of my interview will be available only to the researcher and her supervisor and will be destroyed at the completion of the research.

\section{TICK ONLY ONE BOX}

You have my permission to use my name in published research results.

(initial)

OR

I prefer the information I provide is kept confidential and do not want my comments attributed to me. I choose the following pseudonym:

Please send me a project summary.

Signed:

Date:

Printed name:

Address for results: 